\title{
Interactions between Euwallacea Ambrosia Beetles, Their Fungal Symbionts and the Native Trees They Attack in the Eastern United States
}

Matthew C. Berger

Follow this and additional works at: https://researchrepository.wvu.edu/etd

\section{Recommended Citation}

Berger, Matthew C., "Interactions between Euwallacea Ambrosia Beetles, Their Fungal Symbionts and the Native Trees They Attack in the Eastern United States" (2017). Graduate Theses, Dissertations, and Problem Reports. 5186.

https://researchrepository.wvu.edu/etd/5186

This Thesis is protected by copyright and/or related rights. It has been brought to you by the The Research Repository @WVU with permission from the rights-holder(s). You are free to use this Thesis in any way that is permitted by the copyright and related rights legislation that applies to your use. For other uses you must obtain permission from the rights-holder(s) directly, unless additional rights are indicated by a Creative Commons license in the record and/ or on the work itself. This Thesis has been accepted for inclusion in WVU Graduate Theses, Dissertations, and Problem Reports collection by an authorized administrator of The Research Repository @ WVU. For more information, please contact researchrepository@mail.wvu.edu. 
Interactions between Euwallacea Ambrosia Beetles, Their Fungal Symbionts and the Native Trees They Attack in the Eastern United States

\author{
Matthew C. Berger
}

Thesis submitted to the Davis College of Agriculture, Natural Resources and Design at West Virginia University in partial fulfillment of the requirements for the degree of

\author{
Master of Science \\ in \\ Plant Pathology
}
Dr. Matthew T. Kasson, Ph. D.
Dr. Yong-Lak Park, Ph. D.
Dr. Teiya Kijimoto, Ph. D.

Division of Plant and Soil Sciences

Morgantown, West Virginia

2017

Keywords: Fusarium, ambrosia beetle, pathogenicity, Euwallacea

Copyright 2017 Matthew Berger 


\begin{abstract}
Interactions between Euwallacea Ambrosia Beetles, Their Fungal Symbionts and the Native Trees They Attack in the Eastern United States
\end{abstract}

Matthew C. Berger

In a globalized world, wood products are constantly being shipped from one location to another, along with tiny hitchhikers in the form of insects and microorganisms. Euwallacea validus is a fungus-farming ambrosia beetle native to East Asia that likely made its way to the United States in wood packaging materials in the latter half of the twentieth century. E. validus cultivates two fungal symbionts in the U.S., an unnamed Fusarium sp. (AF-4) and Raffaelea subfusca. Fusarium symbionts of Euwallacea ambrosia beetles as well as Raffaelea symbionts of closely related ambrosia beetles have incited widespread disease on more than one-hundred hosts worldwide. To resolve host range of Fusarium and Raffaelea symbionts from E. validus, inoculation studies, which mimicked natural infestation by creating numerous beetle-size holes along single stems, were conducted on twelve tree species native to the eastern United States known to be natural hosts for this beetle species. Four months post-inoculation, trees were destructively sampled to examine and measure symptoms associated with inoculation. Results of this study showed significant differences in canker incidence and mean streaking associated with inoculation sites, although neither Fusarium sp. AF-4 nor Raffealea symbionts caused significant disease on any host tested and do not appear to pose serious risks to the known hosts within the invaded range of this beetle. Nonetheless several other Euwallacea-Fusarium consortia have been introduced into the U.S. recently which do pose serious risks to avocado production and forest health. PCR multiplexes were recently developed to discriminate closely related AFC symbionts present in the U.S. to monitor their spread and have opened the door for widespread molecular surveillance. This includes testing whether fusaria differ between the native / invaded ranges of these beetles and if symbiont swapping is occurring between beetles whose ranges currently overlap in the U.S. Results of this study confirmed fidelity between certain Euwallacea sp. and their fungal partners such as E. validus and its symbiont, Fusarium sp. AF-4 in both South Korea and the U.S. with no evidence of additional AFC members despite uncovering other FSSC members within mycangial communities. No other Euwallacea spp. examined exhibited obvious fidelity between native and invaded ranges. Surprisingly, a number of known AFC lineages already existing in the U.S. were uncovered from the mycangia of other Euwallacea spp. within the geographic origin of beetles in East Asia. In addition to AFC members, other FSSC isolates were associated with galleries of all five Euwallacea spp. studied, indicating frequent interactions between symbiotic and asymbiotic FSSC members. These results uncovered widespread fungal infidelity among closely related Euwallacea beetles. Such novel beetle-fungus combinations could incite disease across a number of orchard, landscape, and forest trees. 


\section{Acknowledgements}

I want to thank everyone in my life who has supported my somewhat unusual interests which have led me directly to where I am now. First I want to thank all my childhood teachers who fostered my fledgling interests in insects, reptiles, plants and then fungi through the years. These passions led to me West Virginia University where I took classes that I was genuinely interested in. I met Dr. William MacDonald who made me very interested in fungi and he even gave me a job working as a lab technician where I got hands on experience with all sorts of fungi. Dr. Sven Verlinden heightened my love for plants which eventually led to a job as a greenhouse grower where I learned much about the business of plants. Dr. Yong-Lak Park, with his energy and cheerful nature revived my childhood love of insects. These three professors helped me realize that there was a Master of Science program that was the intersection of these three subjects: forest pathology. My time in graduate school was a whole new kind of learning experience for me. I learned firsthand from my peers and professors about the nitty-gritty but absolutely essential parts of science. I want to thank Dr. Daniel Panaccione for his constant advice and for his excellent classes. After taking his genetics class I have become intensely fascinated by a subject that I barely knew before graduate school. I also want to thank Mark Double, a constant source of advice and help in the lab. Dr. Kasson, my advisor, is the most passionate scientist I've ever met. His energy and enthusiasm for science and publishing papers is infectious. I am very grateful that I ended up as his student and got to be involved in the multitude of studies he's engaged in such as Brachycybe millipedes, Massospora on periodical cicadas, ambrosia beetles and their symbionts and more. I am also grateful for the many students I've befriended and have worked with. Cameron Stauder, Amy Metheny, Angie Macias, and especially Kristen Wickert. Kristen has been there the whole way for me, both academically and personally. She's a tough, confident and intelligent woman and great scientist. I'm so glad we have met. Lastly I have to thank my parents. My dad has always been obsessed with science and even though he didn't manage to make a career out of it, he taught me all about astronomy, geology, archeology and to never stop asking questions and to follow my dreams no matter where they lead. My mom has always been there to foster mine and my sibling's interests. She tolerated me bringing snakes and other animals into the house and let me dig up many of the flower beds to make my own native plant gardens. Never did my parents suggest that, all things considered, maybe I should become an engineer or business man so I make lots of money. They not only let me follow my passions, they fueled them and encouraged me to keep at it. For this I am forever thankful that I am so lucky to have them. 


\section{Table of Contents}

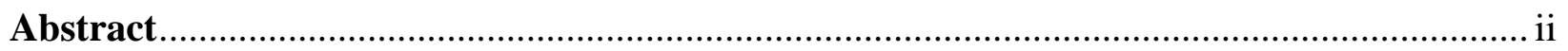

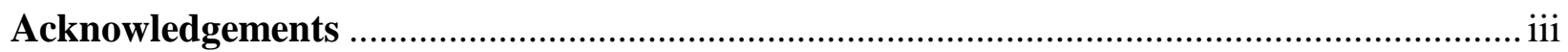

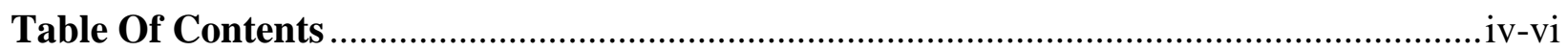

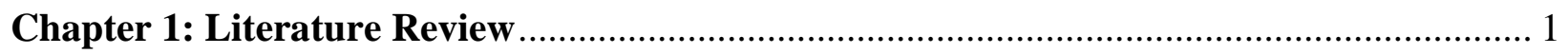

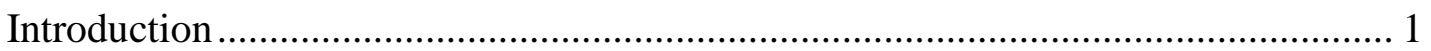

Ambrosia and Bark Beetle Diversity ............................................................ 2

Ambrosia Beetle Biology ............................................................................ 3

Fungal Symbiont Diversity ....................................................................... 4

Transient, low incidence, and phoretic Fungi of ambrosia beetles .......................... 5

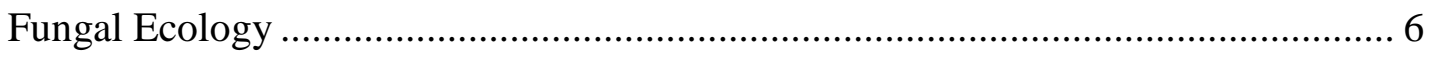

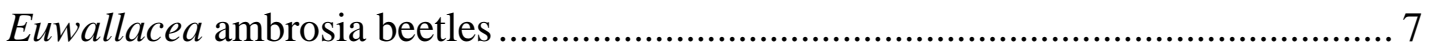

Evidence for Potential Disease Emergence ...................................................... 9

Fusarium symbionts of Euwallacea ............................................................... 10

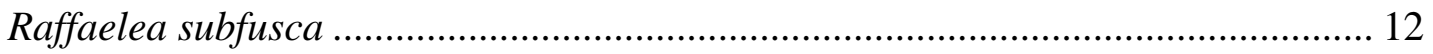

Paracremonium sp. nov. and Graphium sp. nov. .............................................. 13

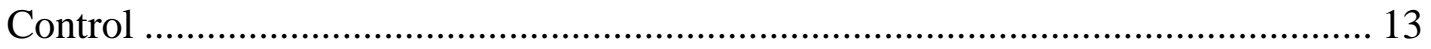

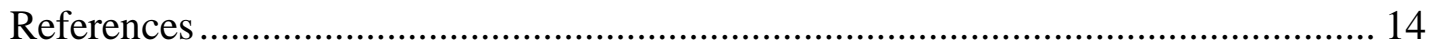

Chapter 2: Detection of Euwallacea validus and Characterization and Pathogenicity of its Fungal Symbionts and Associates on Trees Native to the Eastern United States............. 21

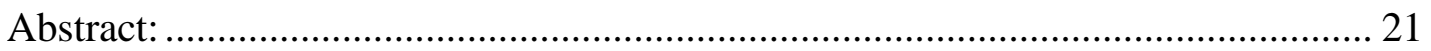




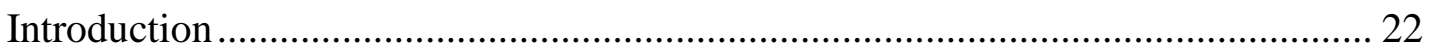

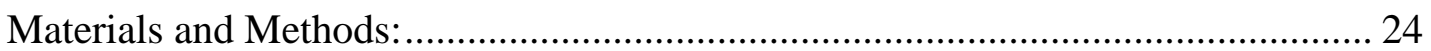

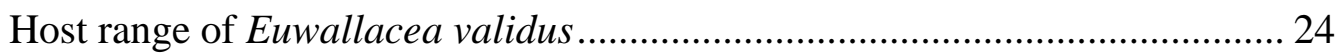

Mycangial communities of E. validus across known tree hosts........................ 25

Isolate selection and inoculum preparation and maintenance ............................ 25

Tree inoculation, experimental design, and disease assessment ....................... 27

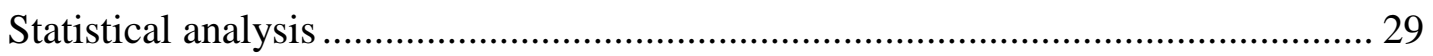

Proportion of mycangial fungi CFUs .............................................................. 29

Effect of treatment, tree species and their interactions on streak area .............. 29

Comparisons of Canker Frequency by Host and Treatment ............................. 30

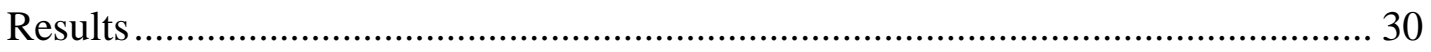

Host Range of Euwallacea validus ................................................................. 30

Mycangial communities of $E$. validus across known tree hosts........................ 31

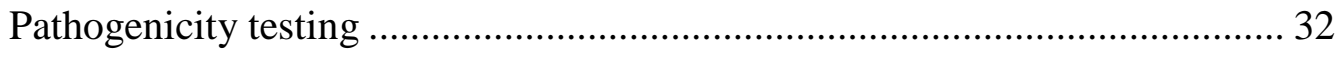

Mean Streaking Area ........................................................................................ 33

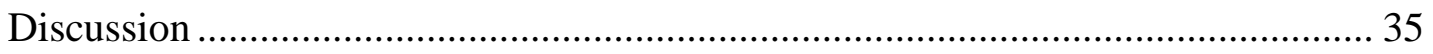

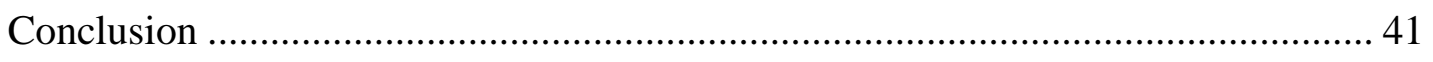

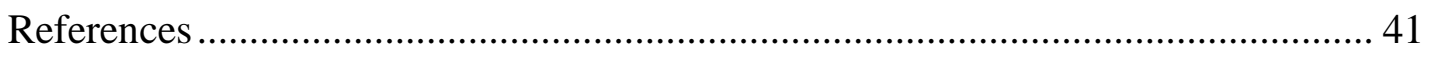

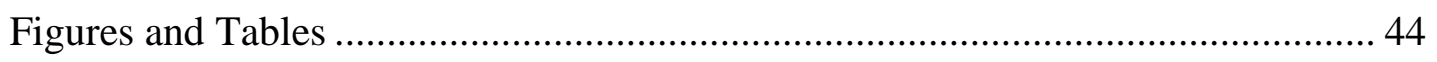

Chapter 3: Fusarium symbiont diversity and fidelity among Euwallacea spp. in their

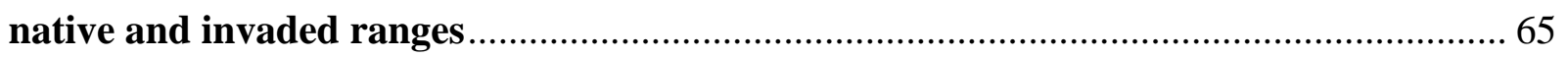




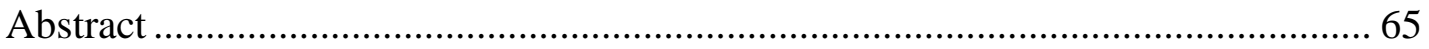

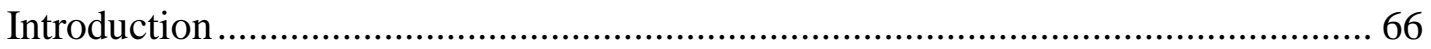

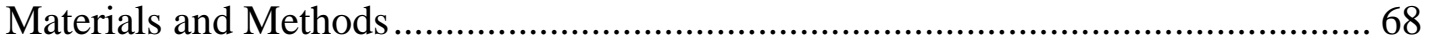

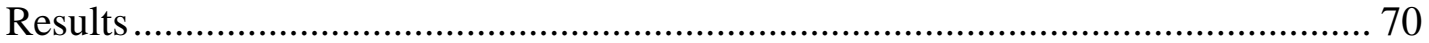

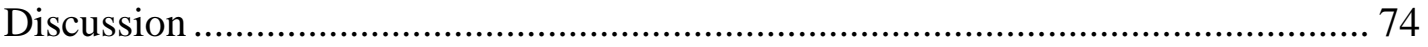

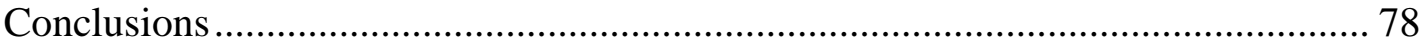

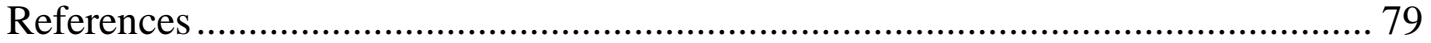

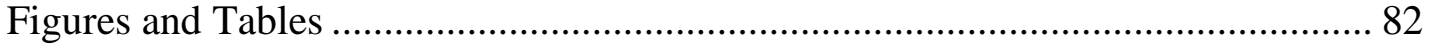

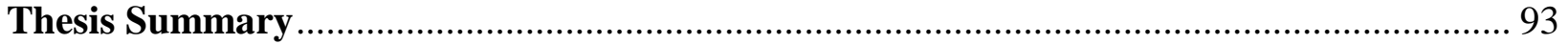

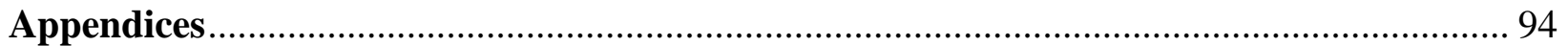




\section{Chapter 1: Literature Review}

\section{Introduction}

In an increasingly globalized world, products are constantly being shipped from one location to another, along with tiny hitchhikers in the form of insects and microorganisms. Products and wood pallets made from local wood can contain wood boring insects as well as fungi, that when set loose in a new country devoid of its natural enemies that mitigate spread, can unleash havoc among native plant species. Of the recorded interceptions of exotic insects by the Animal and Plant Health Inspection Service (APHIS) 60\% of the wood associated beetles are scolytids (bark and ambrosia beetles,) the majority of these are bark beetles (USDA APHIS 1995). As of 1996, all wood packing materials entering the U.S. are required to be debarked (USDA APHIS 1995). This however does not do much to prevent the entry of ambrosia beetles which burrow into the wood itself, regardless of debarking practices. To deal with these, the use of heat treatments and chemical fumigation (i.e.methyl bromide) to kill the wood boring insects, including ambrosia beetles, is now required for imported wood products into the U.S. (Morrell 1995). Unfortunately, not every wood product is properly treated and not all are inspected so insects still make their way into the U.S.

Ambrosia beetles pose a unique threat as they carry the fungi they need to feed on inside or phoretically on their bodies. Fungi are housed within specialized anatomical structures called mycangia and vary in complexity from simple pits to internal pouches. The introduction of an ambrosia beetles into new environments actually results in the introduction of two or more potentially destructive organisms. Ambrosia beetles are attracted to ethanol given off by stressed, dying or recently dead trees (Moeck 1970). Once an ambrosia beetle finds a potential tree host it excavates a tunnel in the wood and inoculates the tunnel with the symbiotic fungi it carries. This fungus then grows on the walls of the tunnel, extracting nutrients from the wood. The beetle then 
eats the spores and hyphae of the fungus to sustain itself. Females then dig tunnels to lay eggs in. Larvae hatch and begin to eat the fungi in their gardens.

Over the last century, several destructive fungal plant pathogens have invaded American landscapes and forests as co-evolved mutualists of exotic bark and ambrosia beetles. Dutch elm disease of American elm, which involves one such bark beetle, the European elm bark beetle, Scolytus multistriatus and its associated Ophiostoma fungi are responsible for the death of over 100 million cultivated elms (Ploetz et al. 2013). Similarly, Raffaelea lauricola, the fungal symbiont of the Asiatic redbay ambrosia beetle, Xyleborus glabratus, has killed hundreds of millions of native lauraceous plants (Lauraceae) throughout the coastal Southeastern U.S. since 2003 including avocado, redbay and sassafras (Fraedrich et al 2008, Ploetz et al. 2013).

\section{Ambrosia and Bark Beetle Diversity}

Beetles (Coleoptera) are the most species rich and diverse order of animals known. They account for about $25 \%$ of all known life forms and of these 400,000 or so described species, about $40 \%$ of these are in the massive family Curculionidae. Curculionidae contains the weevils, bark beetles and ambrosia beetles (Ploetz et al. 2013). Presently there are about 3,200 described species of ambrosia beetles with many more awaiting discovery (Farrell et al., 2001; Jordal and Cognato, 2012; Kirkendall et al., 2015). Bark beetles are obligate phloem feeders and most of these species attack conifers. They are often associated with, but not dependent on fungi which can circumvent tree host defenses and allow the beetles to feed on the tissues with resin ducts plugged by the fungi (Paine et al. 1997). Ambrosia beetles burrow into the less nutritious xylem of a freshly dead or dying tree (usually angiosperms) and do not derive their nutrition directly from the tree but indirectly by inoculating the tunnel with a symbiotic fungus which digests tree tissue and then the beetles feed on this fungus. This habit has evolved from bark beetles on at 
least thirteen occasions (Farrell et al., 2001; Jordal and Cognato, 2012; Kirkendall et al., 2015), but most beetle lineages have never had their fungal mutualists identified.

Fungal farming, or fungiculture, is rare in nature, seen primarily in the insect orders Blattodea (roaches and termites), Hymenoptera (attine ants) Coleoptera: Curculionidae (ambrosia beetles). Other lesser known insects also engage in symbioses with fungi functionally analogous to the ambrosia beetle-fungus symbiosis including ship timber beetles, wood wasps, and stingless bees. The marsh periwinkle has also been shown to farm fungi. Fungal farming in the insects has arisen only once in the attine ants, once in the termites which all cultivate varieties of the fungus Termitomyces but has arisen at least 8 times in the ambrosia beetles allowing for a diversity of fungal symbionts to be acquired (Mueller. 2002, Bateman et al. 2016). Termites and ants all cultivate Basidiomycete fungi whereas most ambrosia beetles depend on Ascomycotan fungi as symbionts.

\section{Ambrosia Beetle Biology}

Ambrosia beetles have evolved several characteristics that make them unique among Coleoptera and aid in their propagation and cultivation of their fungal symbionts. Ambrosia beetles maintain obligate mutualism with their fungal partners for survival and reproduction and therefore must maintain their fungal colonies and move them from tree to tree. Many ambrosia beetles have evolved specialized pouches or structure called mycangia in which they store spores or hyphae of their symbiont. Mycangia have evolved several times and therefore vary across species and include preoral, mandibular, elytral, mesothoracic, and many others (Six 2003), and, in most instances, are phylogenetically highly conserved (Hulcr and Cognato 2010, Batra 1963). In Euwallacea, paired mandibular mycangia are found inside the head at the bases of the 
mandibles behind the labrum ( $\mathrm{Li}$ et al. 2015). Xylosandrus has mycangia between the prothoracic and mesothoracic nota (Ploetz. 2013). When a mature female ambrosia beetle leaves her nursery gallery she takes with her the propagules of her fungi and then bores into a new host tree which is infected by these spores or hyphae, thus continuing the fungal line.

Ambrosia beetles are sexually dimorphic and like many social hymenopterans, male’s roles in life are relegated to mating and not much else (Knížek et al. 2004). This has led to their bodies being remarkably smaller than females of the same species and therefore use less food than the more important females, the loss of flight capability as they typically mate with their sisters inside their natal gallery and have no use for strong flight muscles. Males also lack mycangia and fungi are only occasionally isolated from their bodies (Kasson et al. 2013).

Ambrosia beetles are notable for their haplodiploid sex determination system where females develop from fertilized eggs and are diploid but males develop from unfertilized eggs and are haploid (Peer et al. 2005) These males have only one set of chromosomes and only mate with their sisters or mother. This leads to the curious fact that these males never have fathers or sons but can have grandfathers and grandsons. This adaptation also leads to a fascinating mechanism for removing inbreeding related abnormalities such as recessive lethal and deleterious alleles because they will always be expressed in the haploid males every time they arise which leads to the death of all these individuals, thus preventing such alleles from entering the population (White 1984).

\section{Fungal Symbiont Diversity}

Ambrosia beetles, unlike other fungi farming insects, conserve a range of symbiotic fungi in both the Ascomycota (Ophiostomatales, Microascales, Hypocreales) and Basidiomycota (Polyporales), which comprise the fungal Subkingdom Dikarya. Among the Ophiostomatales, 
Raffaelea is the most well-known fungal genus and includes $R$. lauricola, the fungal symbiont of Xyleborus glabratus, which causes laurel wilt and is responsible for killing millions of lauraceous trees in the southeastern US in its new naïve habitat (Friedrich et al 2008). Euwallacea validus also carries and conserves a Raffaelea sp., $R$. subfusca, whose role in the beetle symbiosis is not yet known (Kasson et al. 2013). Among the Microascales, three genera are known: Ambrosiella, Meredithiella, and Phialophoropsis (Mayers et al. 2015) and include the well-known, Ambrosiella xylebori, Ambrosiella hartigii, Ambrosiella beaveri, and Ambrosiella roeperi, from Xylosandrus, Anisandrus, Cnestus ambrosia beetles (Six. 2009). Euwallacea ambrosia beetles maintain symbiotic relationships with a monophyletic lineage nested within the Fusarium solani species complex (Hypocreales) and include at least twelve species-level lineages, termed AF 1-12, within the monophyletic AFC from seven Fusariumfarming Euwallacea (Kasson et al. 2013, O’Donnell et al. 2015). A recently discovered association between saproxylic Ambrosiodmus and Ambrosiophilus ambrosia beetles (Scolytinae: Xyleborini) and their mutualistic fungal symbiont Flavodon ambrosius (Basidiomycota: Polyporales) is the only known example of a basdiomycetous symbiont (Li et al., 2015; Kasson et al., 2016; Simmons et al., 2016). The newly discovered Flavodon ambrosius allows the beetle to establish large, long-lived, communal colonies with overlapping generations and egg-laying by pre-dispersal progeny females and persist in wood much longer compared to other ambrosia beetles carrying Ascomycetes (Kasson et al., 2016).

Transient, low incidence, and phoretic Fungi of ambrosia beetles Some species of fungi that are occasionally isolated from the mycangia or other parts of ambrosia beetles but have not been found to be nutritional symbionts of the beetle (Kasson et al. 2013, Kostovcik et al. 2015). These fungi are considered important because they are part of the 
mycangial community and have the potential to interact with the host plant or other fungi in the mycangia including passive dissemination of phytopathogenic fungi (Bateman et al. 2016, Juzwik et al. 2016). Euwallacea validus has three species that are occasionally isolated from beetle heads: an unresolved yeast(s) and Paracremonium sp. as well as a previously resolved Graphium sp. (Kasson et al. 2013, Lynch et al. 2015). Although these fungi don't appear vital to the reproductive success of E. validus, they are conserved. A closely related Euwallacea species in California and Israel, Euwallacea sp. \#1, has also been shown to carry closely related fungi, including Paracremonium pembeum and Graphium euwallaceae, both of which have been shown to be pathogenic on avocado and box elder (Lynch. 2016). Yeasts similar to those seen from E. validus have been recently characterized from Ambrosiophilus ambrosia beetles and molecularly identified as Yamadazyma mexicana (Kasson et al. 2016). The role of these yeasts in both bark and ambrosia beetle systems remains unclear.

\section{Fungal Ecology}

Ambrosia beetles are different from other plant feeding insects in that they are not usually host specific and are capable of colonizing and reproducing in a large number of different tree species as long as their mutualistic fungi can grow on the wood. About 95\% of species don’t have host specifications (Hulcr. 2007).

Flavodon ambrosius is unique among ambrosial fungi because it is a Basidiomycete and an aggressive white rotter. It is able to quickly colonize large portions of a tree, providing large amounts of fast nutrition to its symbionts. Ambrosiodmus and Ambrosiophlius are able to quickly develop multigenerational communities in the tree before it rots and breaks due to wood degradation (Li, et al. 2015, Kasson et al. 2016). Most ambrosia beetle symbionts utilize Ascomycetes which are good at extracting nutrients from freshly dead or dying wood but are 
quickly outcompeted by white rotting Basidiomycetes in older, rotting wood (De Fine Licht. 2012). Members of the Ambrosia Fusarium Clade, namely AF-4, the fungal symbionts of Euwallacea ambrosia beetles (Kasson et al. 2013), also produce some lignin-modifying enzymes that likely facilitated the success of this symbiosis (Kasson et al. 2016, Norris 1980)

Some fungi in ambrosia beetle symbioses have evolved to suit the beetle’s nutritional habits. Fusarium species associated with Euwallacea have evolved club shaped spores instead of the typical spindle-shaped macroconidial spores characteristic of the genus Fusarium. It is posited that modified spores likely represent an adaptation towards the symbiosis. Gongylidia and nodules appear to represent analogous adaptations in Agaricalean fungi farmed, respectively, by higher attines (Schultz and Brady, 2008) and termites (Aanen et al., 2002). In both the beetle and ant agricultural systems, (i) nutritious, highly adapted fungal cells (i.e., clavate macroconidia and gongylidia) are produced exclusively within the terminal clades, (ii) beetles and ants cultivate specific symbionts that are mostly transmitted vertically, and (iii) the mutualisms appear to be obligate (Aanen et al., 2002).

\section{Euwallacea ambrosia beetles}

At least six Euwallacea species from Asia have become established within the U.S. over the last four decades (Cognato et al. 2015; O’Donnell et al. 2015): E. interjectus (Blandford), E. validus (Eichhoff), E. denticulus (Motschulsky) and three morphologically cryptic species within the E. fornicatus species complex (Eichhoff) (Atkinson 2016; O’Donnell et al. 2015; Storer et al. 2015).

Euwallacea validus Eichhoff (formerly Xyleborus validus) (Coleoptera: Curculionidae: Scolytinae) is an introduced ambrosia beetle from Asia (first described from Japan) which was 
first detected in the United States on Long Island near New York City (Nassau Co.), New York in 1976 (Wood 1977). As of 2014, distribution of this species includes Delaware (Rabaglia and Valenti 2003), Maryland (Atkinson et al 1991), New Jersey (1996), New York, Pennsylvania, (Coyle et al 2005), Virginia, and West Virginia (1991) (Rabaglia et al 2006), North Carolina (2011), Kentucky (2012), Michigan (2006), Georgia (2012) and Tennessee (2010) (Cognato et al. 2015). Earlier detections of E. validus in the Deep South were recently determined to be the closely related E. interjectus (Cognato et al. 2015). In its native habitat. E. validus is found on a wide range of host genera including Abies, Acanthopannax, Acer, Betula, Carpinus, Castanea, Chamaecypress, Cletha, Cryptomeria, Fagus, Juglans, Malotus, Phellodendron, Pinus, Prunus, Quercus, and Zelkova but has only been reported to attack plants that are dying or recently dead (Shibata et al 1994, Wood 1977). Host genera in the United States include Quercus (Wood, 1980), Ailanthus (Kasson, unpublished data), striped maple, staghorn sumac, and devil’s walkingstick, all of which have been documented in Pennsylvania (Kasson et al. 2015). Similar to Japanese hosts, E. validus apparently attacks only stressed, dying or recently dead trees. In the mid-Atlantic, E. validus is often found in huge numbers on stressed and or dying Verticilliuminfected Ailanthus which naturally occurs in the beetle's native range in China. In epidemic cases of beetle outbreaks, ambrosia beetles may infest nearby healthy trees as well as stressed trees. This infestation can introduce healthy trees to fungal pathogens either by the beetle symbionts or by open wounds formed on the tree from beetle boring (Kuhnholz 2003). This huge local population growth leads to some beetles resorting to attacking healthy nearby trees of various species. This results in the introduction of E. validus's fungal symbionts into the xylem and phloem of normally non-target tree species. Whether E. validus will attack healthy individuals of other host genera here in the U.S. remains unknown. Euwallacea validus is unusual in that it 
cultivates two fungal species in its pre-oral mycangia: Fusarium sp. AF-4, a member of a monophyletic linage within Clade 3 of the Fusarium solani species complex, and Raffaelea subfusca.

In the Mid-Atlantic States, Euwallacea validus usually has one generation per year. Mature female beetles emerge from overwintering galleries from April to May to disseminate to a new tree host to start their own galleries. Females seek out suitable hosts by detecting ethanol given off by stressed or recently dead trees. Once a female finds a potential host tree she bores a test hole, which is often abandoned if the tree is determined not to be a suitable host (Kasson unpublished data). This test hole can be enough to infect the tree with the beetle's symbiotic fungi however. Once she finds a suitable host she bores in and begins excavating galleries to lay eggs in and inoculates the gallery with Fusarium and Raffaelea which grow on the wood. When the eggs hatch the larvae have a ready to eat food source in the form of spores and hyphae. They feed on the fungus until they pupate. When the beetles emerge, most are females but some males also emerge and they are flightless, smaller in size and are typically a lighter color than the females. After the females are mated they overwinter until the spring when they leave their natal gallery to find new host trees and continue the life cycle.

Evidence for Potential Disease Emergence

The primary fungal symbiont of E. validus, Fusarium sp. AF-4 is significant because a similar exotic beetle E. fornicatus carries a closely related Fusarium species which has been shown to cause disease on avocado in California and Israel and is of economic importance there. Infestation of avocado by E. fornicatus is diagnosed by oozing cankers around each beetle hole 
on stems and subsequent wilt and death of branches. When bark is cut away, necrosis of the vascular tissue is evident (Eskalen 2013). Other members of the Fusarium solani species complex, to which Fusarium sp. AF-4 belongs, include many agronomically important phytopathogens including important canker pathogens of several economically important tree hosts (Tisserat 1987, Park and Juzwik 2012).

Similarly another exotic ambrosia beetle, Xyleborus glabratus carries a Raffaelea species symbiont (Raffaelea lauricola) which is responsible for killing millions of native lauraceous plants (Lauraceae) throughout the coastal Southeastern U.S. since 2003 including avocado, redbay and sassafras (Fraedrich et al 2008, Ploetz et al. 2013). This disease is now named laurel wilt since it causes a lethal vascular wilt in infected trees. Interestingly Raffaelea did not apparently evolve as an aggressive plant pathogen but a weak saprotrophic beetle symbiont and the associated wilt is a result of red bay overreacting to the infection by closing off xylem walls in an attempt to compartmentalize the fungus to such an extent that water flow to the top of the tree is cut off and the tree kills itself (Ploetz and Smith 2010).

Xyleborus glabratus frequently attacks healthy lauraceous trees in the southeastern U.S. but does not in its native habitat. This has been thought to be because of a chemical cue mismatch where beetles are attracted to chemicals given off by stressed or recently dead hosts in their native habitat but related tree species in their new territory give off similar compounds when healthy, confusing the beetle into thinking it is infesting a suitable dead or dying host (Kendra P. E. 2010, Hulcr and Dunn 2011).

Fusarium symbionts of Euwallacea

The fusaria associated with Euwallacea ambrosia beetles form a monophyletic group (Ambrosia Fusarium Clade, or AFC) within the Fusarium solani species complex, encompassing 
12 species lineages with known associations with ambrosia beetles (Kasson et al., 2013). Most Euwallacea spp. appear to be associated with one species of Fusarium, but at least two species farm two closely related AFC fusaria. Cophylogenetic analyses of AFC fusaria and Euwallacea indicate that the two phylogenies are largely incongruent, apparently due to the beetles switching fusarial symbionts (i.e., host shifts) at least five times during the evolution of this mutualism (O’Donnell et al 2015). The Fusarium species associated with E. validus is Fusarium sp. AF-4 is the most commonly isolated fungal species from the mycangia. It is also the primary food source for the beetle based on culture-dependent studies of the various lifestages of E. validus (Kasson et al. 2013). It has highly modified macroconidia that have lost the ancestral “canoe” shaped spores and now assume a club like shape (clavate). These spores fit into mycangia more easily and are likely easier to eat. The evolutionary origin of the AFC dates to the early Miocene 21.2 Mya, which coincides with the adaptive radiation of the Xyleborini (Jordal et al. 2000). This is about the time that clavate spores arose.

Despite fidelity among Fusarium-farming Euwallacea, most members of the AFC are morphologically indistinguishable. Up until now studies to resolve closely related symbionts have necessitated DNA sequence analysis of phylogenetically informative loci. However, recent PCR multiplexes developed by Short and colleagues (2017) have identified taxon-specific primer-annealing sites that rapidly distinguish the AFC species currently within the U.S. The rapid assay not only supports federal and state agency efforts to monitor spread of these invasive beetles and mitigate further introductions but will also permit hypothesis testing regarding symbiont co-cultivation and symbiont switching (O’Donnell et al. 2015). This is especially relevant given that E. interjectus overlaps with E. validus at the southernmost extent of the latter species’ known range and the two species vector different AFC species. Because each Euwallacea species has a unique coevolved AFC symbiont needed to survive and reproduce, it 
has been shown that some species cannot survive on even closely related AFC members from related beetles of even the same genus (Freeman. 2013). This doesn't completely rule out the possibility of symbiont swapping and molecular work to be done by the author may determine if symbiont swaps or hybridization occurs.

\section{Raffaelea subfusca}

The genus Raffaelea was established by Arx \& Hennebert (1965) to accommodate Raffaelea ambrosiae, a symbiont of Platypus ambrosia beetles; it currently includes up to 20 described species including the important tree pathogens Raffaelea quercivora, Raffaelea quercus-mongolicae, and Raffaelea lauricola, causal agents of Japanese and Korean oak wilt and laurel wilt, respectively (Dreaden et al. 2014). Raffealea are associated with numerous Xyleborus and Platypodine beetles. Euwallacea validus maintains a symbiotic relationship with Raffaelea subfusca, which is consistently found in roughly equal proportion to Fusarium sp. AF-4 in their mycangia. $R$. subfusca is also known from Xyleborus glabratus, with isolations from beetles recovered in FL, SC, and GA (Harrington et al. 2010). Mixing between beetle and fungal species due to lateral transfer in invaded regions appears to be common for promiscuous symbioses, such as Xyleborus-Raffaelea (Carrillo et al., 2014; Simmons et al., 2016a) or Euwallacea-Fusarium (O’Donnell et al. 2015). The role of this species is not yet known in the E. validus symbiosis but the fact that it is conserved in high numbers suggest that it could be a nutritional symbiont although not vital to the beetle. Raffaelea subfusca is also found in the macerations of Xyleborus glabratus, the beetle that carries Raffaelea lauricola the laurel wilt pathogen (Harrington. 2010). 
Paracremonium sp. nov. and Graphium sp. nov.

Paracremonium is a new genus established from a group of fungi previously treated as Acremonium recifei (now renamed Xenoacremonium recifei L. Lombard \& Crous) (Lombard et al. 2015). Prior to the discovery of P. pembeum, all Paracremonium species were associated with human infections, although numerous Paracremonium-like species are frequent facultative inhabitants of the ambrosia beetles and their galleries (Lombard et al. 2015). Of interest Paracremonium-like fungi are recovered frequently from mycangia and galleries of many ambrosia beetles. The two non-essential and occasional mycangial inhabitants Paracremonium sp. nov. and Graphium sp. nov. are important novel species in that the closely related species $E$. fornicatus in California has also been shown to carry a Paracremonium and Graphium species which have been shown to be pathogenic on avocado and box elder (Lynch. 2016).

\section{Control}

Ambrosia beetles are difficult to control with insecticides, requiring that pesticides be closely timed before tree attack, applied repeatedly, or have long residual activity (Oliver. 2001). The habit of living inside wood and not feeding directly on plant tissues means contact insecticides do little because ambrosia beetles spend most of their life inside wood. A systemic insecticide will not work on dead trees that are infested with ambrosia beetles because the tree's vascular tissues no longer function to move the chemical throughout the tree. Ambrosia beetles are attracted to ethanol and can be trapped using this as a lure, but it is not likely practical for reducing population numbers significantly. Bio-control of ambrosia beetles has been investigated and shown that some strains of Beauvaria bassiana are effective at infecting and killing Xyleborus glabratus under lab conditions but the fungus still takes 3-5 days to kill the beetle. In that time period they were still able to tunnel into hosts trees and infect them with their lethal 
wilt pathogen Raffaelea lauricola. Environmental conditions in the field will likely cause the bio-control to be less effective and expensive to treat large areas of infected trees (Carrillo. 2015).

\section{References}

1. USDA APHIS 1995. 7 CFR Parts 300 and 319 - importation of logs, lumber, and other unmanufactured wood articles. Federal Register, 25 May 1995, 60: 27665 - 27682.

2. Morrell, J. J. (1995). Importation of unprocessed logs into North America: a review of pest mitigation procedures and their efficacy. Forest Products Journal, 45(9), 41.

3. Moeck, H. A. (1970). Ethanol as the primary attractant for the ambrosia beetle Trypodendron lineatum (Coleoptera: Scolytidae). The Canadian Entomologist, 102(08), 985-995.

4. Ploetz, R. C., Hulcr, J., Wingfield, M. J., \& De Beer, Z. W. (2013). Destructive tree diseases associated with ambrosia and bark beetles: black swan events in tree pathology? Plant Disease, 97(7), 856-872.

5. Fraedrich, S. W., Harrington, T. C., Rabaglia, R. J., Ulyshen, M. D., Mayfield Iii, A. E., Hanula, J. L., ... \& Miller, D. R. (2008). A fungal symbiont of the redbay ambrosia beetle causes a lethal wilt in redbay and other Lauraceae in the southeastern United States. Plant Disease, 92(2), 215-224.

6. Farrell, B. D., Sequeira, A. S., O'Meara, B. C., Normark, B. B., Chung, J. H., \& Jordal, B. H. (2001). The evolution of agriculture in beetles (Curculionidae: Scolytinae and Platypodinae). Evolution, 55(10), 2011-2027. 
7. Mueller, U. G., \& Gerardo, N. (2002). Fungus-farming insects: multiple origins and diverse evolutionary histories. Proceedings of the National Academy of Sciences, 99(24), 15247-15249.

8. Kasson, M. T., O’Donnell, K., Rooney, A. P., Sink, S., Ploetz, R. C., Ploetz, J. N., ... \& Smith, J. A. (2013). An inordinate fondness for Fusarium: phylogenetic diversity of fusaria cultivated by ambrosia beetles in the genus Euwallacea on avocado and other plant hosts. Fungal Genetics and Biology, 56, 147-157.

9. White, M. J. (1984). Chromosomal mechanisms in animal reproduction. Italian Journal of Zoology, 51(1-2), 1-23.

10. Alamouti, S. M., Tsui, C. K., \& Breuil, C. (2009). Multigene phylogeny of filamentous ambrosia fungi associated with ambrosia and bark beetles. Mycological research, 113(8), 822-835.

11. Six, D. L., Stone, W. D., de Beer, Z. W., \& Woolfolk, S. W. (2009). Ambrosiella beaveri, sp. nov., Associated with an exotic ambrosia beetle, Xylosandrus mutilatus (Coleoptera: Curculionidae, Scolytinae), in Mississippi, USA. Antonie van Leeuwenhoek, 96(1), 1729.

12. Baker, J. M., \& Norris, D. M. (1968). A complex of fungi mutualistically involved in the nutrition of the ambrosia beetle Xyleborus ferrugineus. Journal of Invertebrate Pathology, 11(2), 246-250.

13. You, L., Simmons, D. R., Bateman, C. C., Short, D. P., Kasson, M. T., Rabaglia, R. J., \& Hulcr, J. (2015). New Fungus-Insect Symbiosis: Culturing, Molecular, and Histological Methods Determine Saprophytic Polyporales Mutualists of Ambrosiodmus Ambrosia Beetles. PloS one, 10(9), e0137689. 
14. Licht, H. H. D. F., \& Biedermann, P. H. (2012). Patterns of functional enzyme activity in fungus farming ambrosia beetles. Frontiers in zoology, 9(1), 1.

15. Cognato, A. I., Hoebeke, E. R., Kajimura, H., \& Smith, S. M. (2015). History of the exotic ambrosia beetles Euwallacea interjectus and Euwallacea validus (Coleoptera: Curculionidae: Xyleborini) in the United States. Journal of economic entomology, tov073.

16. Hulcr, J., Mogia, M., Isua, B., \& Novotny, V. (2007). Host specificity of ambrosia and bark beetles (Col., Curculionidae: Scolytinae and Platypodinae) in a New Guinea rainforest. Ecological Entomology, 32(6), 762-772.

17. Hulcr, J., \& Cognato, A. I. (2010). REPEATED EVOLUTION OF CROP THEFT IN FUNGUS-FARMING AMBROSIA BEETLES. Evolution, 64(11), 3205-3212.

18. Kühnholz, S., Borden, J. H., \& Uzunovic, A. (2001). Secondary ambrosia beetles in apparently healthy trees: adaptations, potential causes and suggested research. Integrated Pest Management Reviews, 6(3-4), 209-219.

19. Eskalen, A., Stouthamer, R., Lynch, S. C., Rugman-Jones, P. F., Twizeyimana, M., Gonzalez, A., and Thibault, T. (2013). Host range of Fusarium dieback and its ambrosia beetle (Coleoptera: Scolytinae) vector in southern California. Plant Disease, 97: 938-951.

20. Kendra, P. E., Montgomery, W. S., Niogret, J., Peña, J. E., Capinera, J. L., Brar, G., ... \& Heath, R. R. (2011). Attraction of the redbay ambrosia beetle, Xyleborus glabratus, to avocado, lychee, and essential oil lures. Journal of chemical ecology, 37(9), 932-942.

21. Jordal, B. H., Normark, B. B., \& Farrell, B. D. (2000). Evolutionary radiation of an inbreeding haplodiploid beetle lineage (Curculionidae, Scolytinae). Biological Journal of the Linnean Society, 71(3), 483-499. 
22. Freeman, S., Sharon, M., Maymon, M., Mendel, Z., Protasov, A., Aoki, T., ... \& O’Donnell, K. (2013). Fusarium euwallaceae sp. nov.-a symbiotic fungus of Euwallacea sp., an invasive ambrosia beetle in Israel and California. Mycologia, 105(6), 1595-1606.

23. Harrington, T. C., Aghayeva, D. N., \& Fraedrich, S. W. (2010). New combinations in Raffaelea, Ambrosiella, and Hyalorhinocladiella, and four new species from the redbay ambrosia beetle, Xyleborus glabratus. Mycotaxon, 111(1), 337-361.

24. Lynch, S. C., Twizeyimana, M., Mayorquin, J. S., Wang, D. H., Na, F., Kayim, M., ... \& Hucr, J. (2016). Identification, pathogenicity and abundance of Paracremonium pembeum sp. nov. and Graphium euwallaceae sp. nov.-two newly discovered mycangial associates of the polyphagous shot hole borer (Euwallacea sp). in California. Mycologia, 15-063.

25. Oliver, J. B., \& Mannion, C. M. (2001). Ambrosia beetle (Coleoptera: Scolytidae) species attacking chestnut and captured in ethanol-baited traps in middle Tennessee. Environmental Entomology, 30(5), 909-918.

26. Carrillo, D., Dunlap, C. A., Avery, P. B., Navarrete, J., Duncan, R. E., Jackson, M. A., ... \& Peña, J. E. (2015). Entomopathogenic fungi as biological control agents for the vector of the laurel wilt disease, the redbay ambrosia beetle, Xyleborus glabratus (Coleoptera: Curculionidae). Biological Control, 81, 44-50.

27. Mendel, Z., Protasov, A., Sharon, M., Zveibil, A., Yehuda, S. B., O’Donnell, K., ... \& Freeman, S. (2012). An Asian ambrosia beetle Euwallacea fornicatus and its novel symbiotic fungus Fusarium sp. pose a serious threat to the Israeli avocado industry. Phytoparasitica, 40(3), 235-238. 
28. Storer, C. G., Breinholt, J. W., \& Hulcr, J. (2015). Wallacellus is Euwallacea: molecular phylogenetics settles generic relationships (Coleoptera: Curculionidae: Scolytinae: Xyleborini). Zootaxa, 3974(3), 391.

29. De Fine Licht HH, Biedermann PHW. (2012). Patterns of functional enzyme activity in fungus farming ambrosia beetles. Front Zool; 9:13. doi: 10.1186/1742-9994-9-13 PMID: 22672512.

30. Talbot PHB.(1977). The Sirex-Amylostereum-Pinus association. Annu Rev Phytopathol. $15: 41-54$.

31. C. Menezes, A. Vollet-Neto, A.J. Marsaioli, D. Zampieri, I. Cardoso Fontoura, A.D. Luchessi, V.L. Imperatiz-Fonseca. (2015) A Brazilian social bee must cultivate fungus to survive. Curr. Biol., 25 (2015) 2851-2855.

32. Silliman, B.R. \& Newell, S.Y. (2003). Fungal farming by a snail. Proceedings of the National Academy of Sciences, USA.

33. Six DL. (2003). Bark beetle-fungus symbioses. In: Bourtzis K, Miller TA, editors. Insect symbiosis. New York, New York: CRC Press; pp. 97-114.

34. Batra LR. (1963). Ecology of ambrosia fungi and their dissemination by beetles. Trans Kansas Acad Sci. 66(2):213-236.

35. Kostovcik, Martin, Craig C. Bateman, Miroslav Kolarik, Lukasz L. Stelinski, Bjarte H. Jordal, and Jiri Hulcr. (2015). The ambrosia symbiosis is specific in some species and promiscuous in others: evidence from community pyrosequencing. The ISME journal 9, no. 1 (2015): 126-138. 
36. Dreaden, T.J., Davis, J.M., De Beer, Z.W., Ploetz, R.C., Soltis, P.S., Wingfield, M.J. and Smith, J.A. (2014). Phylogeny of ambrosia beetle symbionts in the genus Raffaelea. Fungal biology, 118(12), pp.970-978.

37. Paine, T. D., K. F. Raffa, and T. C. Harrington. (1997). Interactions among scolytid bark beetles, their associated fungi, and live host conifers. Annual review of entomology 42.1 179-206.

38. Peer, Katharina, and Michael Taborsky. (2005). Outbreeding depression, but no inbreeding depression in haplodiploid ambrosia beetles with regular sibling mating. Evolution 59.2: 317-323.

39. Knížek, M., and R. Beaver. (2004). Taxonomy and systematics of bark and ambrosia beetles. Bark and Wood Boring Insects in Living Trees in Europe, a Synthesis 41-54.

40. O’Donnell, K., Sink, S., Libeskind-Hadas, R., Hulcr, J., Kasson, M. T., Ploetz, R. C., ... \& Duncan, R. E. (2015). Discordant phylogenies suggest repeated host shifts in the Fusarium-Euwallacea ambrosia beetle mutualism. Fungal Genetics and Biology, 82, 277290.

41. Wood. (1977) The bark and ambrosia beetles of north and central America (Coleoptera: Scolytidae), a Taxonomic Monograph. Great Basin Naturalist Memoirs. Pg. 810.

42. Rabaglia, R. J. (2003). Annotated list of the bark and ambrosia beetles (Coleoptera : Scolytidae) of Maryland, with new distributional records. Proceedings of the Entomological Society of Washington 105: 373-379.

43. Rabaglia, R. J. , S. A. Dole , and A. I. Cognato . (2006). Review of American Xyleborina (Coleoptera: Curculionidae: Scolytinae) occurring north of Mexico, with an illustrated key. Annals of the Entomological Society of America 99: 1034-1056. BioOne 
44. Tisserat, N. 1987. Stem canker of black-walnut caused by Fusarium solani in Kansas. Plant Dis. 71:557.

45. Park, J. H., and Juzwik, J. 2012. Fusarium canker of bitternut hickory caused by Fusarium solani in the north-central and northeastern United States. Plant Dis. 96:455. 46. Kasson, M. T., O’Neal, E. S., \& Davis, D. D. (2015). Expanded host range testing for Verticillium nonalfalfae: potential biocontrol agent against the invasive Ailanthus altissima. Plant Disease, 99(6), 823-835.

47. Short, D. P., O’Donnell, K., Stajich, J. E., Hulcr, J., Kijimoto, T., Berger, M. C., ... \& Lynch, S. C. (2017). PCR Multiplexes Discriminate Fusarium Symbionts of Invasive Euwallacea Ambrosia Beetles that Inflict Damage on Numerous Tree Species Throughout the United States. Plant Disease, 101(1), 233-240. 


\section{Chapter 2: Detection of Euwallacea validus and Characterization and}

\section{Pathogenicity of its Fungal Symbionts and Associates on Trees Native to the Eastern United States}

Abstract: Euwallacea ambrosia beetles vector members of the ambrosia Fusarium clade (AFC), a monophyletic clade within the Fusarium solani species complex (FSSC). Some of these AFC lineages have been shown to cause dieback and canker diseases on over one-hundred hosts worldwide. In addition to cultivating a novel lineage of Fusarium (Fusarium sp. AF-4) within the AFC, E. validus consistently co-cultivates a second fungal partner, Raffaelea subfusca, which hasn't been detected in other Euwallacea spp. Unlike other Euwallacea introductions to the U.S., little is known regarding the relative importance of a second fungal partner or pathogenicity of both fungal symbionts of $E$. validus despite this beetle being the most widespread and longest established of the five confirmed species currently present within the U.S. To better understand the dynamic s between the two fungal symbionts, mean CFU counts were compared across 17 plant hosts, many of which have been recently discovered. Results indicated Fusarium sp. AF-4 dominated mycangial communities from beetles from 11 plant hosts compared to $R$. subfusca, which dominated communities from three plant hosts. To resolve host range of both symbionts, inoculation studies were conducted on 12 native trees found to be suitable hosts for the beetle including 5 species that are confirmed reproductive hosts of this beetle. To simulate infestation, inoculum for each of the two symbionts was injected into 10 beetle-sized, artificially drilled holes for each 20 trees for twelve individual native tree hosts as well as Ailanthus excluding controls. Four months after inoculation, trees were destructively sampled to quantify and measure cankers, measure streaking, and observe associated symptoms. Results of this study 
showed significant differences in canker incidence and mean streaking associated with inoculation sites, although a majority of plant hosts exhibited both symptoms in the negative control treatment as well. Red oak was exceptional in that all fungal treatments had significantly higher canker counts compared to the negative control, which had none. Overall, mean streaking area was significantly larger in Fusarium AF-4 treatments compared to all other treatments across all plant hosts. Among tree hosts, Ailanthus and staghorn sumac had significantly greater streaking areas across all treatments compared to eleven and six plant hosts, respectively, with the exception of each other. Reisolations from symptomatic tissues failed to recover the target fungi that were inoculated into their respective trees for a majority of the inoculations regardless of treatment. Highest recovery of target fungi were from black birch (46\%) followed by red oak (21\%), red maple (13\%), tulip poplar (8\%), and hackberry (4\%). Together these results indicate neither Fusarium sp. AF-4 nor Raffealea symbionts caused significant disease on any host tested. Although Fusarium symbionts of other Euwallacea introduced into the U.S. pose serious risks to avocado production and forest health, the symbionts of E. validus do not appear to pose serious risks to the known hosts within the invaded range of this beetle.

\section{Introduction}

Over the last few decades, several destructive fungal plant pathogens vectored by exotic bark and ambrosia beetles (Coleoptera: Curculionidae: Scolytinae) have invaded American landscapes and forests. Included among these are members of the Fusarium solani species complex, symbionts of Euwallacea ambrosia beetles from Asia, that have become established within the U.S. (Cognato et al. 2015; O’Donnell et al. 2015). Most Euwallacea spp. colonize declining and recently killed trees. Some, however, are able to colonize living trees, sometimes in massive numbers, and can cause symptoms known as Fusarium dieback or Fusarium canker. Euwallacea validus Eichhoff (formerly Xyleborus validus) (Coleoptera: Curculionidae: 
Scolytinae) is the earlier detected Euwallacea ambrosia beetle in the United States, reported from Long Island (Nassau Co.), New York in 1976 (Wood 1977). As of 2014, distribution of this species includes Delaware, Maryland, New Jersey (1996), Pennsylvania, Virginia, and West Virginia (1991), North Carolina (2011), Kentucky (2012), Michigan (2006), Georgia (2012) and Tennessee (2010) (Cognato et al. 2015, Rabaglia et al 2006).

The primary fungal symbiont of E. validus, Fusarium sp. AF-4 is significant because a similar exotic beetle E. fornicatus carries a closely related Fusarium species which has been shown to cause disease on avocado in California and Israel and is of economic importance there. Infestation of avocado by E. fornicatus is diagnosed by oozing cankers around each beetle hole on stems and subsequent wilt and death of branches. When bark is cut away, necrosis of the vascular tissue is evident (Eskalen 2013). Other members of the Fusarium solani species complex, to which Fusarium sp. AF-4 belongs, include many agronomically important phytopathogens including important canker pathogens of several economically important tree hosts (Tisserat 1987, Park and Juzwik 2012).

In addition to AF-4, E. validus maintains a second fungal symbiont, $R$. subfusca (Kasson et al. 2013), which is unique among Euwallacea ambrosia beetles reported thus far. This fungus is consistently found in equal proportion to Fusarium sp. AF-4 in their mycangia. Raffaelea currently includes up to 20 described species including the important tree pathogens Raffaelea quercivora, Raffaelea quercus-mongolicae, and Raffaelea lauricola, causal agents of Japanese and Korean oak wilt and laurel wilt, respectively. Raffealea are associated with numerous Xyleborus and Platypodine beetles (Dreaden et al. 2014).

In addition to its coevolved fungal symbionts, two other fungi, Graphium sp, and a Paracremeonium are occasionally recovered from mycangia and more commonly from the exoskeleton where spores are carried phoretically (Lynch et al. 2016). Closely related species in 
these same two genera have also been associated with the PHSB in CA (Lynch et al. 2016) and have been reported as pathogens of avocado and boxelder (Acer negundo) in that region.

The objectives of this study were to (i) determine the plant host range of E. validus, and (ii) determine if infestations of E. validus on native plant coincide with disease symptoms, (iii) determine if fungal communities from E. validus vary depending on plant host, and (iv) test the pathogenicity of dominant mycangial fungi from E. validus on their known hosts.

Materials and Methods:

Host range of Euwallacea validus

To determine the host range of Euwallacea validus, we sought out Verticillium-infected tree-of-heaven (Ailanthus altissima) stands where E. validus had been previously confirmed (Kasson personal communication). Verticillium is a fungal pathogen which causes vascular wilting and subsequent death on Ailanthus. These recently dead and dying trees are very attractive to ambrosia beetles. All tree species in close proximity to these disease epicenters were visually inspected for crown symptoms indicative of decline and closely examined for signs of ambrosia beetle activity including holes and fresh frass tubes. Upon detection, beetles were destructively removed using a hammer and chisel to confirm the target beetle. Upon confirmation, trees were felled and infected bolts were brought back to the lab for complete beetle extraction. Beetles were forcibly removed from infested bolts by splitting logs and clapping logs over a clean surface to permit collection of ejected beetles of all life stages. 
Mycangial communities of E. validus across known tree hosts

Mycangial communities were characterized as previously described by Kasson et al. (2013) for each life stage present in any given host. When available, a minimum of 10 adult females and two adult males were samples to permit comparisons between their fungal communities. Briefly, beetles that had been extracted from infested bolts were surface disinfested in 95\% ethanol and heads aseptically removed, placed in sterile water, and crushed. Following serial dilution plating of head macerates, individual fungal colony forming units (CFUs) were quantified by morphotype and representatives of each morphotype retained for molecular characterization and/or pathogenicity tests.

Several males and other life stages were occasionally extracted from logs. Males were processed the same as females and pupae and larva were macerated whole to and the macerate processed like the aforementioned females (Fig. 4).

\section{Isolate selection and inoculum preparation and maintenance}

Two isolates of Fusarium sp. AF-4, two isolates of Raffeala subfusca, and 1 Graphium sp. isolate were selected for pathogenicity testing on thirteen E. validus hosts (Table 1). All isolates were recovered from infested Ailanthus on the Evansdale campus of West Virginia University.

Cultures were maintained on Glucose Yeast Extract Agar (GYEA) amended with streptomycin sulfate and tetracycline in a controlled environment chamber at $23^{\circ} \mathrm{C}$ for $7-10$ days. Inoculum was prepared by adding 3-5 $\mathrm{ml}$ of sterile distilled water amended with $1 \%$ peptone to 3-week-old cultures of each of the five fungus treatments and scraping the surface with a sterile glass rod. Conidial concentrations were determined using a hemocytometer and adjusted to 1.20 
$-1.65 \times 10^{6}$ conidia ml-1. Viability of conidia was evaluated by counting CFU from 10 -fold dilutions of suspensions on GYEA plates. Inoculum was maintained at $4^{\circ} \mathrm{C}$ until viability was confirmed.

For long-term maintenance of tester strains, mycelial plus were harvested from 2-4-weekold pure cultures and transferred to potato dextrose agar (PDA) slants, permitted to colonize the agar at room temperature for 3-4 weeks and stored at $4^{\circ} \mathrm{C}$.

\section{Site and Host selection}

The study area spanned five locations and four counties in WV (Table 2). Specific locations included Cooper's Rock State Forest and WVU Research Forest (Preston Co.), Mountwood County Park (Wood Co.), WVU Evansdale woodlot (Monongalia Co.), and I-79 corridor near Fairmont, WV (Marion Co.). Sites were chosen based on species composition, ease of access, and permission to carry out pathogenicity testing.

Host were chosen based on 2015 confirmed hosts of E. validus with a few exceptions. White ash was not inoculated because of widespread emerald ash borer infestations resulting in few healthy and/or asymptomatic trees prior to the start of the experiment. Common serviceberry (Amelanchier arborea) was excluded due to low incidence in the northern WV region. Eastern hemlock (Tsuga canadensis), American beech (Fagus grandifolia), and black cherry (Prunus serotina) were excluded on account of them only having been confirmed as hosts after the initiation of the experiment. Included hosts had a range of diameters and are reported in Table 2. A minimum diameter of $2 \mathrm{~cm}$ was chosen to permit adequate stem space for ten inoculation sites. 
Tree inoculation, experimental design, and disease assessment

To mimic natural infestations and subsequent fungal inoculation by E. validus, 10 1/16" diameter holes were drilled to a depth of 1-1.5 cm. $20 \mathrm{ul}$ of spore solution for each of the five fungal treatments or water plus peptone for the negative control was pipetted into individual holes with a pipettor and subsequently covered with plumber's putty (Oatey Plumbing Supplies, Cleveland, $\mathrm{OH}$ ) to keep moisture in to permit successful colonization.

A minimum 10 trees for each tree host for each of three fungal species used, Fusarium sp. AF-4, R. subfusca, and Graphium sp., were inoculated at ten sites per stem, ranging from 6-1' above soil line (Table 3). For both Fusarium sp. AF-4 and R. subfusca, two isolates, both of which originated from E. validus in WV, were used, five trees per isolate. For Graphium sp., a single isolate was used with ten trees inoculated. Since Graphium sp. was only recovered from Ailanthus and Black birch, only these two species were challenged with this fungus. All thirteen species were challenged with both isolates of Fusarium sp. AF-4 and R. subfusca. For each tree, inoculation sites were arranged in a clockwise downward spiral as to ensure individual sites did not overlap. Inoculation sites were also circled with a lumber crayon to make it easy to find the inoculation sites 3.5 months after inoculation.

Mean crown dieback, canker incidence and mean streaking length associated with wounding/cankers was evaluated 3.5-4 months after inoculation. For canker incidence, all inoculated trees were assessed by destructively removing a $2 \times 2 \mathrm{~cm}^{2}$ bark section around each inoculation site with a chisel and hammer. After their removal, presence/absence data was taken for each inoculation point including negative controls for each of 13 inoculated tree species. After recording canker incidence, two of five trees per treatment were randomly chosen for enhanced assessment to measure total streaking length for 20 inoculation sites. Length and width 
measurements were taken for each cambial streak and recorded. For crown ratings, estimations of the percentage of the tree crown with live, chlorotic, necrotic, and wilted foliage, to the nearest 5\% were recorded. Re-isolations were conducted for 3 of ten inoculation sites of each of two trees for which streaking data was taken.as described above.

For fungal isolations, colonized bark plugs from symptomatic tissues (cankers / cambial streaking) were collected and isolated from as previously described (Short et al. 2015). Bark plugs were surface disinfected in 5\% sodium hypochlorite for $14 \mathrm{~min}$, transferred onto glucose yeast extract agar (GYE) containing streptomycin (Sigma-Aldrich, St. Louis, MO, USA) and tetracycline

(Fisher Scientific, Pittsburgh, PA, USA), and grown at ambient temperature following a 16-h light/8-h dark cycle. Re-isolations from $R$. subfusca inoculated trees were different from the remaining treatments in that bleach treated wood plugs were transferred to a selective growth media, OSA, which contains Cycloheximide and permits growth of slow growing fungi like Raffealea with reduced risk of contamination. For long-term storage, cultures were transferred to PDA slants and maintained at $4^{\circ} \mathrm{C}$.

Mycelia were harvested from isolates growing on media plates, and transferred to 1.5-ml Eppendorf tubes and crushed with micropestles. Genomic DNA was extracted using a Wizard kit (Promega, Madison, WI, USA). DNA was suspended in 751 Tris-EDTA (TE) buffer preheated to $65^{\circ} \mathrm{C}$.

For molecular ID, portions of the internal transcribed spacer (ITS) region were used. For putative non-AF-4 Fusarium isolates, portions of the elongation factor (EF) region were used to get more accurate identities within the Fusarium solani complex. The resulting PCR fragments were sequenced and used as queries in BLASTN searches of the Genbank NR database. For re- 
isolations from Fusarium sp. AF-4 inoculated trees, an AF-4 specific multiplex described by Short et al. 2017 was used.

Statistical analysis

Proportion of mycangial fungi CFUs

When comparing the relative amount of colony forming units (CFUs) recovered from individual beetle heads between the primary symbionts of E. validus, AF-4 and Raffaelea subfusca, a chi-squared test was performed across all tree species. Results of the tests were deemed significant if $\mathrm{p}<0.05$.

To examine if there were differences in the relative amount of colony forming units (CFUs) recovered from individual beetle heads between the primary symbionts of E. validus, AF-4 and Raffaelea subfusca within individual species, a second chi-squared test was performed for each individual species. Results of the tests were deemed significant if $\mathrm{p}<0.05$.

\section{Effect of treatment, tree species and their interactions on streak area}

Streak area for each tree species was evaluated for normality using the Shapiro-Wilk W test. The results of this test showed 6 of 13 species were not normally distributed (positively skewed, data not shown). To meet the assumptions of Analysis of Variance (ANOVA), the reciprocal root of area was taken for all 13 species, after which all were found to be normally distributed, thus permitting use of two-way ANOVA. Mean streak areas by treatment, host species, and their interaction were examined. Results of these individual tests were deemed significant if $\operatorname{Pr}>\mathrm{F}<0.05$. Differences among tree species and treatment least squares means were assessed using the Tukey-Kramer method. Slice effects used preplanned multiple 
comparison of treatments within each species, with Tukey-Kramer adjustment for multiple comparisons (controlling the Type I error rate).

\section{Comparisons of Canker Frequency by Host and Treatment}

Cochran-Mantel-Haenszel Statistics (Based on Contingency Table Scores) were used to compare canker prevalence among treatments controlling for tree species. A chi-squared test was used for assessing individual species. A second chi-squared test was performed across treatments for a subset of tree hosts, where negative control treatments resulted in no canker development. Results of these tests were deemed significant if $\mathrm{p}<0.05$.

Results

Host Range of Euwallacea validus

Determination of host range for E. validus was carried out from May 2015 through June 2016. A total of seventeen native hosts were uncovered, a majority of which were found in 2015 in close proximity to Verticillium-infected and beetle colonized Ailanthus stands (Kasson et al. 2013, Table 4). Several of these hosts had been previously determined to serve as hosts for $E$. validus including striped maple, devil’s walkingstick, and staghorn sumac (Kasson et al. 2015). Of the seventeen confirmed native hosts, E. validus attacks were found to be more geographically widespread on several hosts including striped maple, red maple, tulip-poplar, and American beech (Table 4). Based on the limited observations from infested stems in this study, only five species were found to be suitable reproductive hosts for the beetle including tulippoplar, Virginia pine, bigtooth aspen, chestnut oak, and striped maple. Euwallacea validus was observed attacking live, albeit stressed, trees for a majority of hosts. In some cases, symptoms such as gumming, streaking and cankers were observed in association with beetle attacks (Fig. 1, 
Table 4). The remainder of confirmed hosts were dead at the time of beetle extraction. Interestingly, gallery morphology varied by species, a majority of which had typical forked galleries (Fig. 2, Table 4). A few species including black cherry, black birch, black locust, red oak, and chestnut oak, had aberrant gallery morphology ranging from circumferential galleries just under the bark in black cherry to exclusive colonization of bark tissues in oaks (Table 4, Fig. 2).

\section{Mycangial communities of E. validus across known tree hosts}

Mycangial communities were characterized from beetles extracted from seventeen native host trees and Ailanthus, which served as a reference since fungal communities had been previously elucidated from this plant host. A majority of beetles sampled were females as previous studies confirmed the presence of paired pre-oral mycangia from their heads but not from males. Furthermore, males were only recovered from three plants hosts at very low incidence which limited the ability to make comparisons across hosts. Overall, $R$. subfusca and Fusarium sp. AF-4 comprised $84 \%$ of all fungal CFUs from female heads across all plant hosts with AF-4 yielding significantly more CFU's (ca. 8,250) compared to R. subfusca (ca. 6,200)( p $<0.0001)$. The remainder included miscellaneous yeasts and other fungi including Paracremonium sp., Graphium sp., and a variety of singleton taxa that were not further characterized. Incidence of each of the two symbionts from heads of female E. validus was compared across and within plant hosts. Overall, significant differences were detected across hosts indicating that the relative proportion of the two symbionts varied across hosts with a majority of beetles from a majority of plant hosts yielding higher counts of Fusarium sp. AF-4 (Fig. 3, Appexdix A). Of these, beetles from 11 plant hosts had significantly higher total CFU counts of Fusarium sp. AF-4 compared to Raffaelea subfusca. Only five species had mean 
percent incidence of Fusarium sp. AF-4 below 50\% including white ash, Virginia pine, bigtooth aspen, chestnut oak, and serviceberry (Fig. 3, Appendix B). Of these, white ash, Virginia pine, and chestnut oak had significantly higher total CFU counts of Raffaelea subfusca compared to Fusarium sp. AF-4 (Fig. 10).

\section{Pathogenicity testing}

A total of 345 trees were inoculated across 12 native trees species and Ailanthus. Six trees including five buck-rubbed staghorn sumac and one cucumber magnolia (Magnolia acuminata), mistaken for red maple during winter stem selection, were eliminated for obvious reasons. Of the remaining 339 stems, 3390 inoculation sites were evaluated, of which 1380 were destructively sampled to include the full extent of symptomatic tissue. 410 inoculation sites were microsampled to confirm fungal ID and fulfill Koch’s postulates. Seventy-two representative isolates representing each of 10 morphotypes including the main symbionts and other common wood-associated fungi that were present in high numbers from sampled cankers (Table 6).

Prior to the termination of the study the primary target measurement was canker area. However, following termination of the experiment and subsequent canker assessment, it was observed that most trees lacked canker measurements beyond boundary of the initially drilled hole, rendering such comparisons useless. Instead, it was decided that canker incidence coupled with associated streaking width and length measurements, which included any canker present, would serve as a more robust metric for treatment response. Symptomatic tissues were typically vascular streaking and small cankers (Fig. 5) 


\section{Mean Streaking Area}

Treatment and tree species were found to be highly significant with a $\operatorname{Pr}>\mathrm{F}<0.0003$ for treatment and $\operatorname{Pr}>\mathrm{F}<0.0001$ for tree species respectively (Appendix C). Treatment*species interactions were not significant (Appendix C). Similar to canker incidence, mean streaking area varied significantly among treatments across all hosts (Appendix C). Overall inoculations using Fusarium sp. AF-4 isolates WV8 and WV10 had significantly larger streaking area compared to inoculations using R. subfusca and the negative control (Fig. 6A). Among tree hosts, Ailanthus and staghorn sumac had significantly greater streaking areas across all treatments compared to eleven and six plant hosts with the exception of each other (Fig. 6B). In comparison, Virginia pine and striped maple had significantly reduced streaking areas compared to six and two other plant hosts, respectively. Comparisons of individual treatments by species revealed significantly larger mean streaking area for hackberry inoculated with Fusarium sp. AF-4 WV8 and WV10 compared to all other treatments. Comparisons among Fusarium sp. AF-4 WV10 with $R$. subfusca WV110 and the negative control showed near significantly larger canker areas for the former species.

\section{Canker incidence}

Canker incidence varied significantly among treatments across hosts including devil's walkingstick $(\mathrm{p}=0.0003)$, tulip-poplar $(\mathrm{p}=0.0003)$, bigtooth aspen $(\mathrm{p}=0.0166)$, black birch ( $<0.0001)$, chestnut oak $(\mathrm{p}<0.0001)$, red oak $(\mathrm{p}<0.0001)$, and black locust $(\mathrm{p}=0.0057)$ (Appendix D). Canker incidence was highest for tulip-poplar, black locust, and bigtooth aspen, all exhibiting cankers on $>50 \%$ of all inoculation sites regardless of treatment (Fig. 9A, Appendix D). Red oak also had a high incidence of cankers although only from $43 \%$ of inoculation sites. Among fungal treatments, inoculations with Fusarium sp. AF-4 isolate WV8 
(treatment 1) and AF-4 isolate WV10 (treatment 2) yielded the highest number of cankers (230 and 207, respectively), a trend observed with bigtooth aspen, followed by 190 and 181 for $R$. subfusca isolates WV3 (treatment 3) and WV110 (treatment 4) and 168 for the negative control (for negative control cankers see below). For red oak, inoculations with both isolates for each of the two symbionts yielded significantly higher canker incidence compared to the negative control, which yielded none and unlike the other tree hosts, appears to represent a treatment response (Fig. 9B).

\section{Recovery of fungi from inoculated trees}

Overall, reisolations from symptomatic tissues failed to recover the target fungi that were inoculated into their respective trees. Symbionts were recovered less than $8 \%$ of sampled cankers. Highest recovery of target fungi were from black birch (46\%) followed by red oak (21\%), red maple (13\%), tulip poplar (8\%), and hackberry (4\%). The remaining trees yielded none of the inoculated fungi. Across these five inoculated tree species, inoculation sites treated with Fusarium sp. AF-4 isolate WV8 and Raffaelea subfusca isolate WV3 had the highest incidence of recovery with 7 reisolations a piece, Fusarium sp. AF-4 isolate WV10 was recovered from 5 inoculation sites followed by $R$. subfusca isolate WV110 with 3 recovered isolates (Fig. 7).

72 fungal isolates recovered had their DNA extracted and sequenced as described in the methods. The resulting sequences either confirmed or rejected our putative fungal identification based on morphological observations. Results show that many of the putative species were positively identified to genus. Non-target, opportunistic fungi recovered are mostly plant pathogens eg. Pestalotiopsis, Colletotrichum, Fusarium solani, Diaporthe eres, Cytospora, 
Leptosphaeria sp. or saprotrophs eg. Ascocoryne sarcoides, Mucorales, Stereum complicatum, Penicillium, and Trichoderma (Fig. 8, Table 6).

Discussion

Host range of Euwallacea validus

A majority of ambrosia beetles are generalists when it comes to selecting a host plant. Not surprisingly, Euwallacea species are generally known as having a wide range of host trees from many different plant families as evidenced by (Eskalen et al. 2013.) One of the goals in this study was to determine what tree species are at risk of Euwallacea validus infestation in the eastern United States. Tree-of-heaven (Ailanthus altissima) was found to be a preferred host and large scale infestations have been observed in stands of Ailanthus infected with Verticillium wilt (Kasson et al. 2013). When local populations of E. validus explode in such areas, they have been observed opportunistically infesting 17 native tree species, 15 angiosperms and two conifers, both living and dead, with a preference for stressed and weakened angiosperms (Table 4).

Of the 18 tree species identified as host of the beetle, six, including Ailanthus, were confirmed as reproductive hosts using the same criteria described in the paper (Eskalen et al. 2013) (Table 4), though it is likely that some of the other hosts are also suitable for reproduction due to the huge number of active holes and beetles retrieved from the surface of the logs. A number of species actively infested by E. validus couldn't be confirmed as reproductive hosts during our study because the infested material were too large to split in the field or in areas where sampling was not permitted. This meant larvae, eggs, pupae and teneral adults couldn't be recovered.

Some trees identified as hosts of E. validus, but not confirmed reproductive hosts, are speculated to be overwintering spots for the adult female beetles as evidenced by the short non- 
branching hibernaria. When spring arrives the beetle may emerge and find a suitable reproductive host to establish natal galleries. When E. validus bores into a tree to the point it bores into the vascular cambium, the living tissues of the tree are exposed to the two fungal symbionts and other mycangial community members and subsequent infection is possible even if the tree species isn't a suitable reproductive host.

Mycangial communities of E. validus across known tree hosts

The two known fungal symbionts of Euwallacea validus, Fusarium sp. AF-4 and Raffaelea subfusca, were consistently recovered from the macerated heads of E. validus in all of the tree species the beetle was found infesting, with a slightly significantly higher proportion of AF-4 propagules than $R$. subfusca on average (Fig. 10). Among the other mycangial community members were various species of yeasts, Graphium sp. nov. and Paracremonium sp. nov. Related Graphium and Paracremonium are known from Euwallacea fornicatus and may have to potential to be plant pathogens of native tree species (Lynch et al. 2016).

Euwallacea validus is unusual in its conservation of two fungal symbionts and their roles are not entirely understood. Ambrosia Fusarium clade (AFC) members appear to be the primary food source for all Euwallacea spp. based on their coevolutionary history, and the fact that all Euwallacea spp. in the United States strictly conserve AFC members (Kasson et al. 2013.), but $R$. subfusca is always found in abundance in E. validus head macerations. It was postulated that R. subfusca was conserved because it grows better on certain host plants than AF-4, thus giving E. validus a larger potential host range, but results showing that the relative abundance of propagules of the two species changes little between host plants leads to some doubt in this 
theory. $R$. subfusca may be a nutritional supplement, providing nutrients AF-4 may be low in, thus adding to the fitness of developing $E$. validus beetles.

\section{Pathogenicity testing}

To test the pathogenicity of the fungi inoculated in this experiment two metrics were examined: canker incidence and mean streaking area. Initially canker area was going to be used as a metric of pathogenicity, however upon visualizing the inoculation sites it was apparent that cankers, when present, were so small and localized to just a thin ring around the drill hole, that measurements would be useless for purposes of comparison. Instead, canker incidence was used as a metric.

While identifying host trees and recovering beetles from them, dark vascular streaking was noticed in the wood above and below individual beetle entrance holes (Fig. 1). The size of this streaking was also used as a metric of pathogenicity. Upon visualizing inoculation sites, it became apparent that almost every single treatment in every tree showed signs of vascular streaking suggesting that it is a host response to drilling damage and/or spore inoculation.

The possibility for branch dieback was taken into account based on previous results showing that the Euwallacea sp. \#2 and its symbiont, Fusarium sp. AF-2, caused substantial dieback in many species in California (Eskalen et al. 2013). Initially, crown health was also assessed for each tree in the study, but 3.5 months post inoculation, no changes in crown status was observed in any of the tested trees (Table 2). This suggests that AF-4, Raffaelea subfusca and Graphium sp. are not as virulent in the tree species tested in our study. 


\section{Canker incidence}

Inoculation of AF-4 into the vascular cambium of living trees was expected to cause canker formation on some of the native tree species tested. When AFC members were inoculated into living avocado in Israel, significant cankers formed in only 6 weeks (Mendel et al. 2012.) Given an incubation period of 3.5 months during the summer gave the fungi ample time to grow in the host tree. Our results show that even with an extended incubation period, the vast majority of cankers, when they do occur, are very small and only occur as a small necrotic region immediately around the drill hole.

On trees species where there is a large incidence of these tiny cankers, canker formation appears to be a host response to the drilling, rather than a treatment response. These data suggests that none of the fungi tested in this experiment are canker forming pathogens on any of the 13 tree species tested with the exception of northern red oak, which had significantly more cankers in all four of the fungal treatments compared to the negative control (Fig. 9).

\section{Mean Streaking Area}

Vascular streaking occurred on 3356 of 3390 (99\%) of all visualized inoculation sites but varied significantly in area among treatments across all hosts. Vascular streaking is therefore likely a host response to being drilled into and fungi being allowed to enter the vascular cambium. The differences in streak length between treatments however show that some fungi are better at moving and growing within the vascular tissues. Fusarium sp. AF-4 isolates WV8 and WV10 had significantly larger streaking area compared to inoculations using $R$. subfusca and the negative control (Fig. 6). This is not surprising as Fusarium is a genus containing many plant pathogens which can survive in and feed on living trees. 
Raffaelea is a genus of vascular wilt pathogens, which when virulent, clog up vascular tissues or cause the host plant to wall off infected vessels with tyloses in an attempt to compartmentalize the pathogen, preventing further spread. Raffaelea subfusca does not appear to be a vascular wilt pathogen on any of the trees tested in this study, but the fungus did manage to persist in the tree's vascular tissues for at least 3.5 months as the fungus has been reisolated from symptomatic tissues (Fig. 7).

Negative control treatments also exhibited vascular streaking in the majority of inoculation sites. This isn't too surprising because the natural world is rife with opportunistic fungi. A drill hole into a tree is an easy access point for ubiquitous plant pathogens and saprotrophs. In some cases these opportunistic plant pathogens are much more virulent than the inoculated fungi in this study. This likely accounts for the fact that bigtooth aspen had significantly larger streaking in the negative control versus the inoculated fungi. Because treatments 1, 2, 3, and 4 had high spore concentrations injected into the open drill hole wound, these fungi colonized the site quickly, not giving more aggressive opportunistic fungi the chance to colonize these sites.

\section{Recovery of fungi from inoculated trees}

Isolating target fungi from wood plugs is a good way to confirm Koch’s postulates, but it also an imperfect way. There are usually many species of fungi occupying a wood plug taken from symptomatic tissues, you may not always get target fungi that really are in the wood plug because other fungi may grow faster and don’t allow the target to grow out and be identified. For this reason, 4 wood plugs were taken from each inoculation site in an attempt to increase the odds that the inoculated target fungus would grow and be identified. 
Recovery of inoculated fungi from symptomatic tissues away from the initial inoculation site confirms Koch's postulates, proving that these fungal species can grow and be recovered from diseased wood (Table 5). AF-4 isolates (treatments 1 and 2) were recovered 12 times from 4 different tree species: northern red oak, black birch, tulip poplar and red maple. These isolates were confirmed as AF-4 by microscopic examination of their clavate macroconidia and by using PCR multiplexes developed by Short et al. (2017) for the 12 known AFC members.

Raffaelea subfusca (treatments 3 and 4) were recovered and molecularly confirmed by sequencing the internally transcribed spacer (ITS) region, 5 times from 4 hosts: northern red oak, black birch, red maple and devil's walkingstick. $R$. subfusca is difficult to isolate from wood materials because it is very slow growing on media and other fungi often grow from the same wood plug faster and hide or suppress the growth of $R$. subfusca. Because of this, $R$. subfusca treatment wood plugs were placed on cyclohexamide containing media to suppress the growth of other fungi, allowing the cyclohexamide tolerant $R$. subfusca to grow out.

Many samples of non-target, opportunistic fungi were also isolated and are of interest to this study. The bore holes of Euwallacea validus create an open wound and entry site for opportunistic plant pathogens as do the artificial holes created by drilling into the trees. The presence of high numbers of E. validus on the landscape may create significant entryways for opportunistic plant pathogens. Some of the most commonly recovered genera of opportunistic plant pathogens are Fusarium solani complex (of which the AFC is a clade), Colletotrichum and Pestalotiopsis. Other commonly recovered fungi include various Trichoderma spp. and Penicillium spp. These two genera are generally saprotrophs, although some of the recovered Trichoderma spp. are known parasites of other fungi (Table 5, Table 6). 
Conclusion

Identifying tree species that Euwallacea validus infests gives foresters and scientists information about what trees will be susceptible to an emerging disease associated with $E$. validus, should one arise. Although this study suggests that none of the fungi that E. validus harbors are virulent pathogens on any of the tree hosts tested, the beetle itself has the ability to transmit pathogens from one tree to another. Kasson et al. 2013. showed that E. validus was capable of carrying spores of the virulent pathogen Verticillium nonalfalfae from one Ailanthus tree to another. Further examination of the roles of mycangial associates such as Graphium and Paracremonium is warranted and may shed light on their coevolutionary history with E. validus.

\section{References}

1. Cognato, A. I., Hoebeke, E. R., Kajimura, H., \& Smith, S. M. (2015). History of the exotic ambrosia beetles Euwallacea interjectus and Euwallacea validus (Coleoptera: Curculionidae: Xyleborini) in the United States. Journal of economic entomology, tov073.

2. O’Donnell, K., Sink, S., Libeskind-Hadas, R., Hulcr, J., Kasson, M. T., Ploetz, R. C., ... \& Duncan, R. E. (2015). Discordant phylogenies suggest repeated host shifts in the Fusarium-Euwallacea ambrosia beetle mutualism. Fungal Genetics and Biology, 82, 277290.

3. Wood. (1977) The bark and ambrosia beetles of north and central America (Coleoptera: Scolytidae), a Taxonomic Monograph. Great Basin Naturalist Memoirs. Pg. 810.

4. Rabaglia, R. J. 2003. Annotated list of the bark and ambrosia beetles (Coleoptera : Scolytidae) of Maryland, with new distributional records. Proceedings of the Entomological Society of Washington 105: 373-379. 
5. Rabaglia, R. J. , S. A. Dole, and A. I. Cognato . 2006. Review of American Xyleborina (Coleoptera: Curculionidae: Scolytinae) occurring north of Mexico, with an illustrated key. Annals of the Entomological Society of America 99: 1034-1056. BioOne

6. Eskalen, A., Stouthamer, R., Lynch, S. C., Rugman-Jones, P. F., Twizeyimana, M., Gonzalez, A., and Thibault, T. (2013). Host range of Fusarium dieback and its ambrosia beetle (Coleoptera: Scolytinae) vector in southern California. Plant Disease, 97: 938-951.

7. Tisserat, N. 1987. Stem canker of black-walnut caused by Fusarium solani in Kansas. Plant Dis. 71:557.

8. Lynch, S. C., Twizeyimana, M., Mayorquin, J. S., Wang, D. H., Na, F., Kayim, M., ... \& Hucr, J. (2016). Identification, pathogenicity and abundance of Paracremonium pembeum sp. nov. and Graphium euwallaceae sp. nov.-two newly discovered mycangial associates of the polyphagous shot hole borer (Euwallacea sp). in California. Mycologia, 15-063.

9. Dreaden, T.J., Davis, J.M., De Beer, Z.W., Ploetz, R.C., Soltis, P.S., Wingfield, M.J. and Smith, J.A. (2014). Phylogeny of ambrosia beetle symbionts in the genus Raffaelea. Fungal biology, 118(12), pp.970-978.

10. Park, J. H., and Juzwik, J. 2012. Fusarium canker of bitternut hickory caused by Fusarium solani in the north-central and northeastern United States. Plant Dis. 96:455.

11. Mendel, Z., Protasov, A., Sharon, M., Zveibil, A., Yehuda, S. B., O’Donnell, K., ... \& Freeman, S. (2012). An Asian ambrosia beetle Euwallacea fornicatus and its novel symbiotic fungus Fusarium sp. pose a serious threat to the Israeli avocado industry. Phytoparasitica, 40(3), 235-238.

12. Kasson, M. T., O’Donnell, K., Rooney, A. P., Sink, S., Ploetz, R. C., Ploetz, J. N., ... \& Smith, J. A. (2013). An inordinate fondness for Fusarium: phylogenetic diversity of 
fusaria cultivated by ambrosia beetles in the genus Euwallacea on avocado and other plant hosts. Fungal Genetics and Biology, 56, 147-157.

13. Kasson, M. T., O’Neal, E. S., \& Davis, D. D. (2015). Expanded host range testing for Verticillium nonalfalfae: potential biocontrol agent against the invasive Ailanthus altissima. Plant Disease, 99(6), 823-835.

14. Short, D. P., Double, M., Nuss, D. L., Stauder, C. M., MacDonald, W., \& Kasson, M. T. (2015). Multilocus PCR assays elucidate vegetative incompatibility gene profiles of Cryphonectria parasitica in the United States. Applied and environmental microbiology, 81(17), 5736-5742.

15. Short, D. P., O’Donnell, K., Stajich, J. E., Hulcr, J., Kijimoto, T., Berger, M. C., ... \& Lynch, S. C. (2017). PCR Multiplexes Discriminate Fusarium Symbionts of Invasive Euwallacea Ambrosia Beetles that Inflict Damage on Numerous Tree Species Throughout the United States. Plant Disease, 101(1), 233-240. 
Figures and Tables
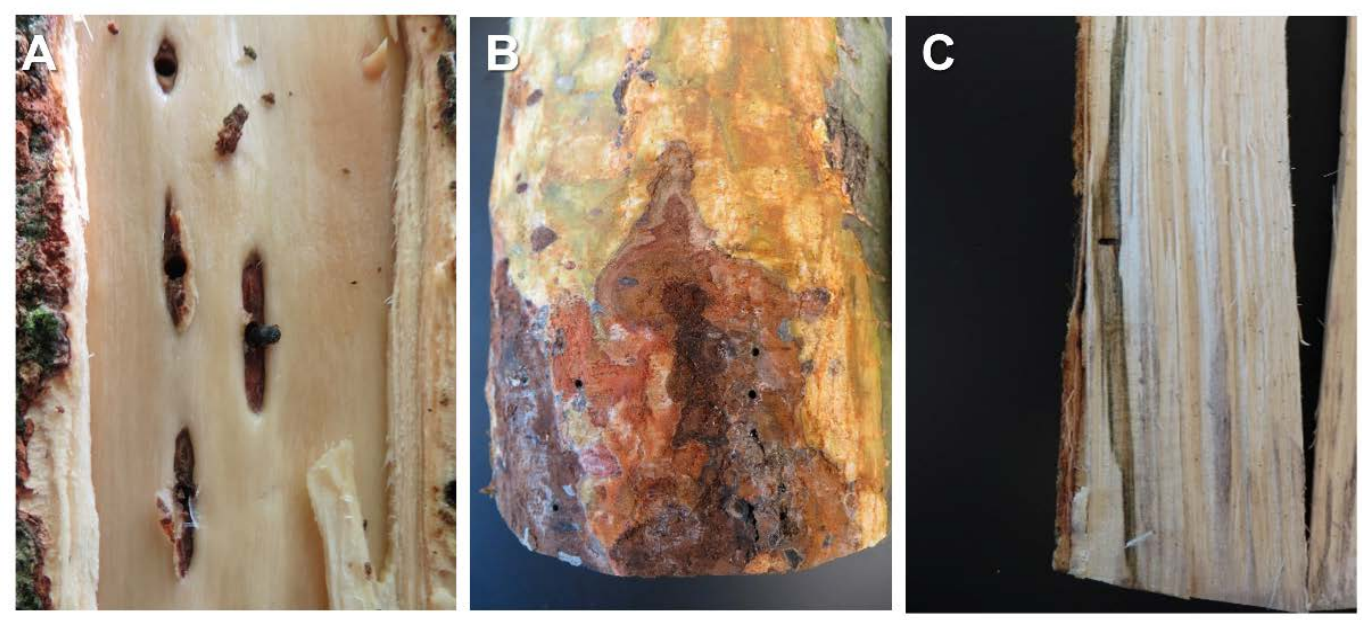

Figure 1. Naturally occurring cankers and streaking associated with A) Euwallacea interjectus infestations on living boxelder in FL, B) E. validus attacks on living black birch in PA, and C) $\underline{E}$. validus attacks on living red maple $\mathrm{i}$ 

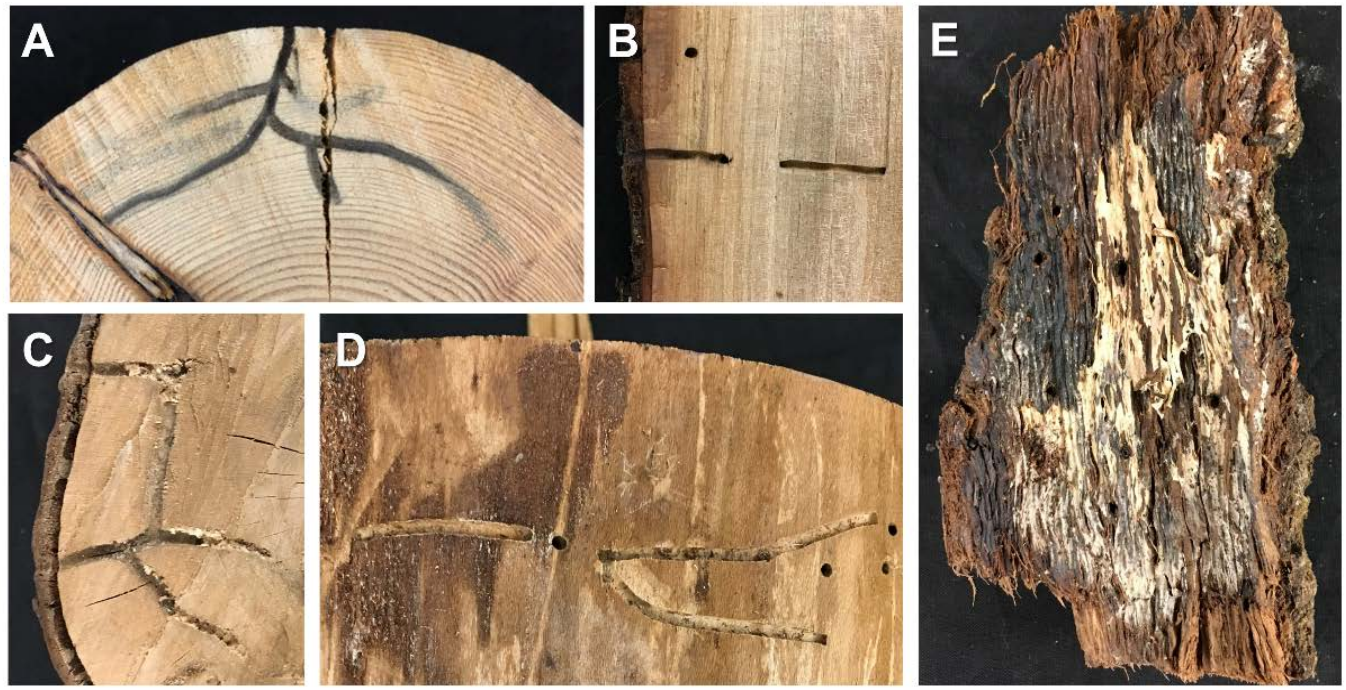

Figure. 2. Euwallacea validus gallery morphologies including. A,C) forked gallery on Virginia pine and striped maple, respectively; B) straight entrance hole without gallery in black birch, D) circumferential forked gallery immediately underneath bark of black cherry, and E) superficial bark colonization of chestnut oak. 


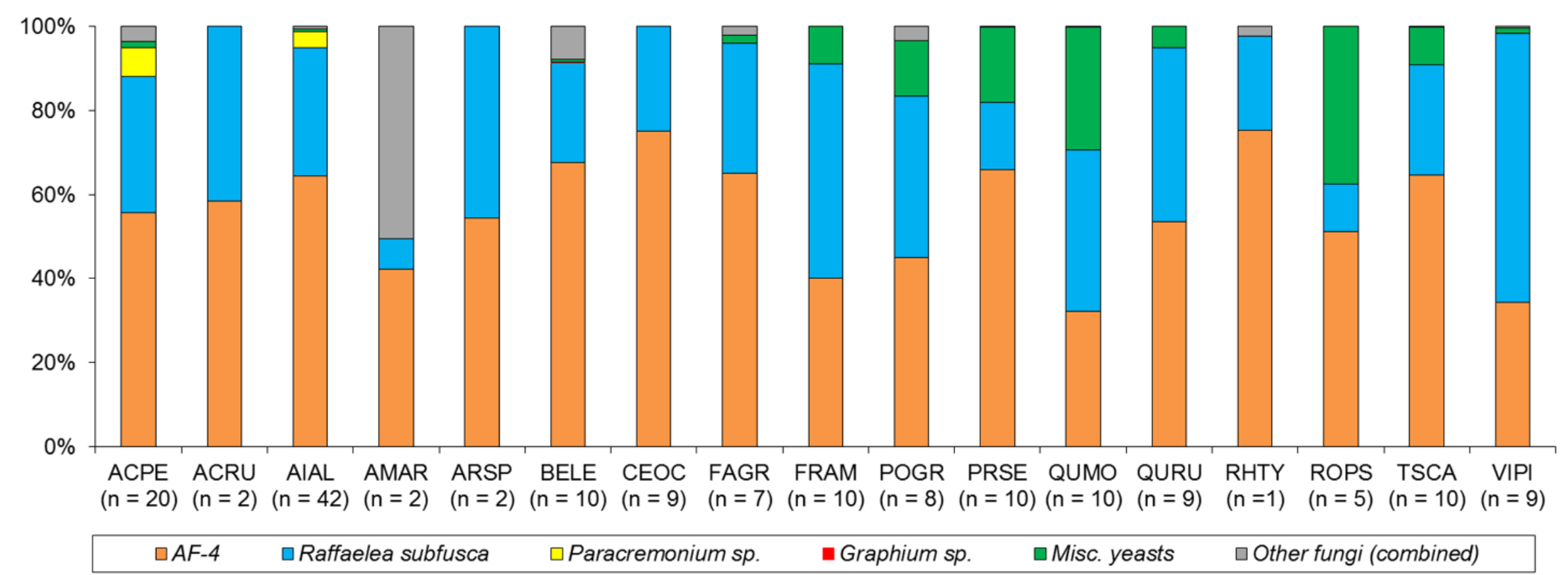

Figure. 3. Percent incidence of fungal community members recovered from adult female E. validus extracted from colonized tree hosts. Sample sizes are listed below each tree host. 

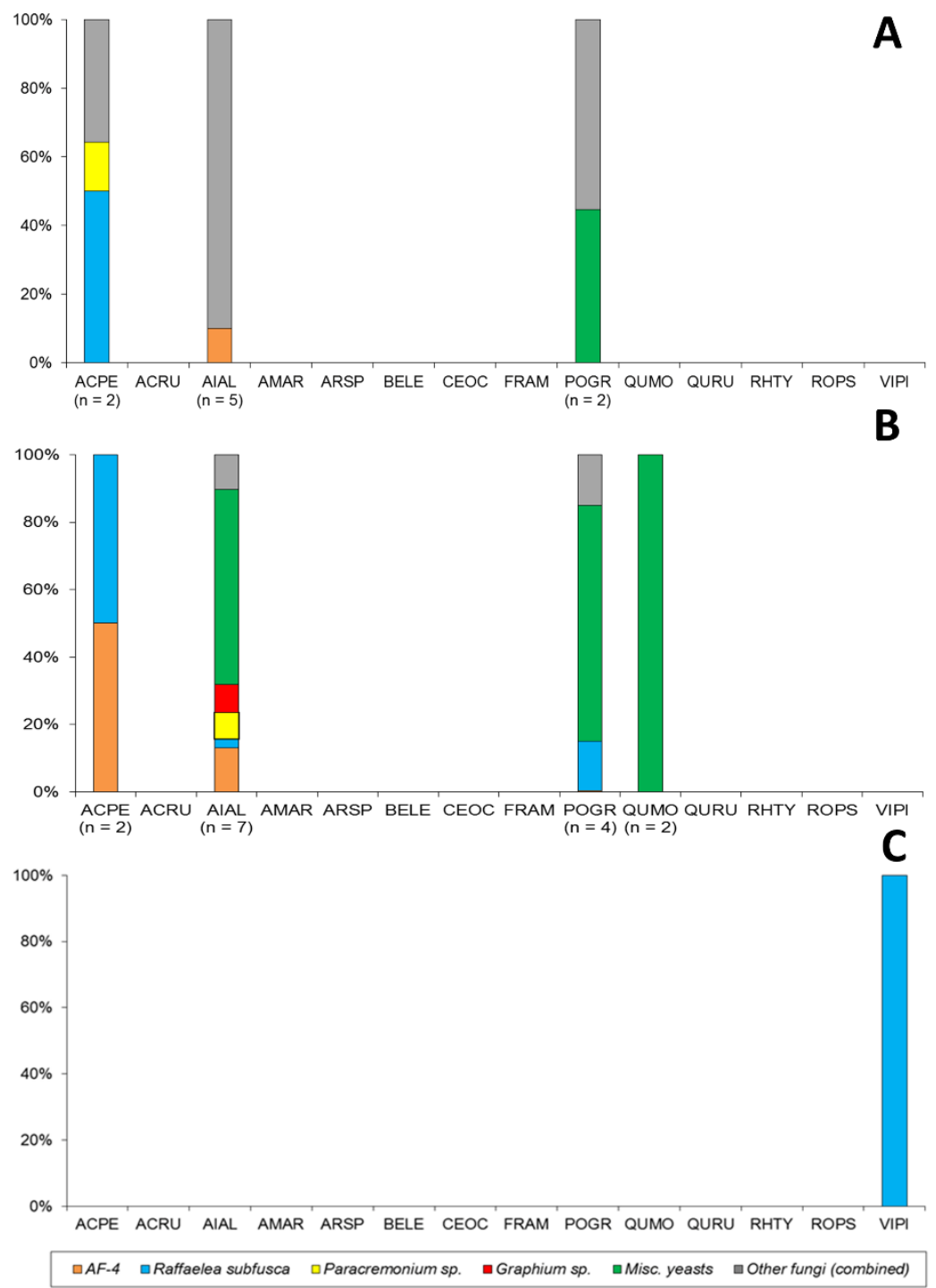

Figure. 4. Percent incidence of fungal community members recovered from various life stages of E. validus excluding females extracted from colonized tree hosts. Sample sizes are listed below each tree host. 

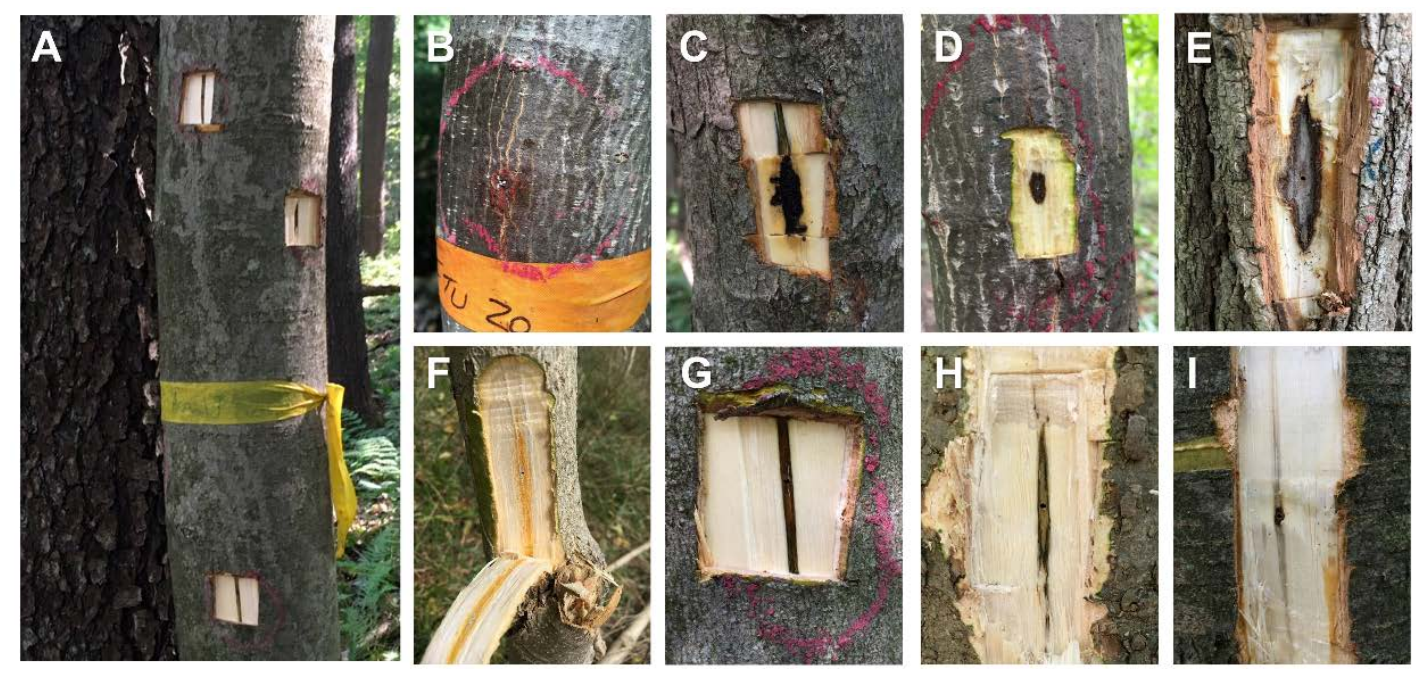

Figure. 5. Symptomatic tissues following artificial inoculation including vascular streaking in A,I) black birch, G) red maple, and H) hackberry; bark discoloration in B) tulip-poplar; and cankers in C) red maple, D) tulip-poplar, and E) black locust. 

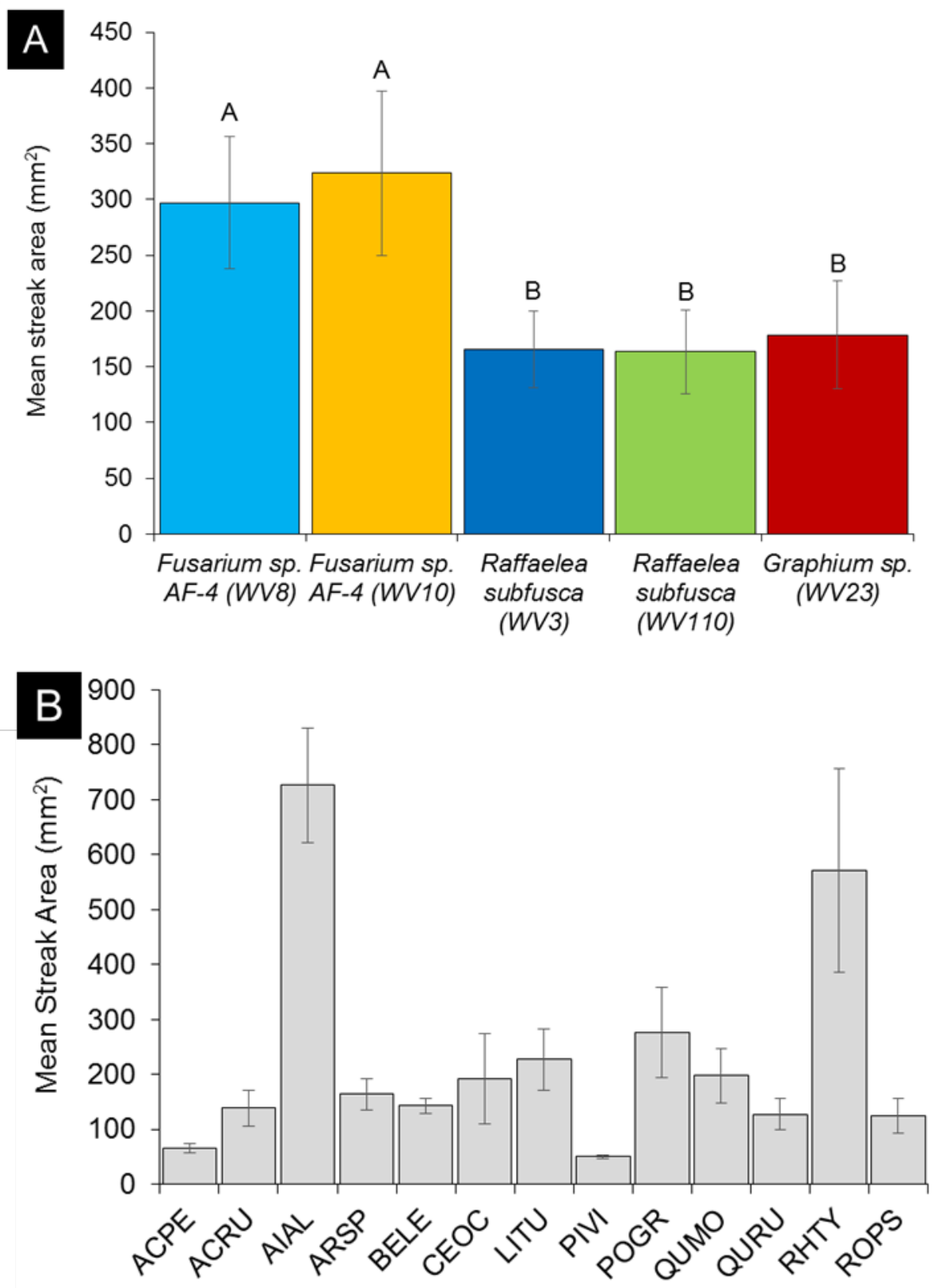

Figure 6. A) Mean streak area among each treatments across all tested hosts 3.5 months post-inoculation. B) Mean streak of each species tested 3.5 months post-inoculation. 


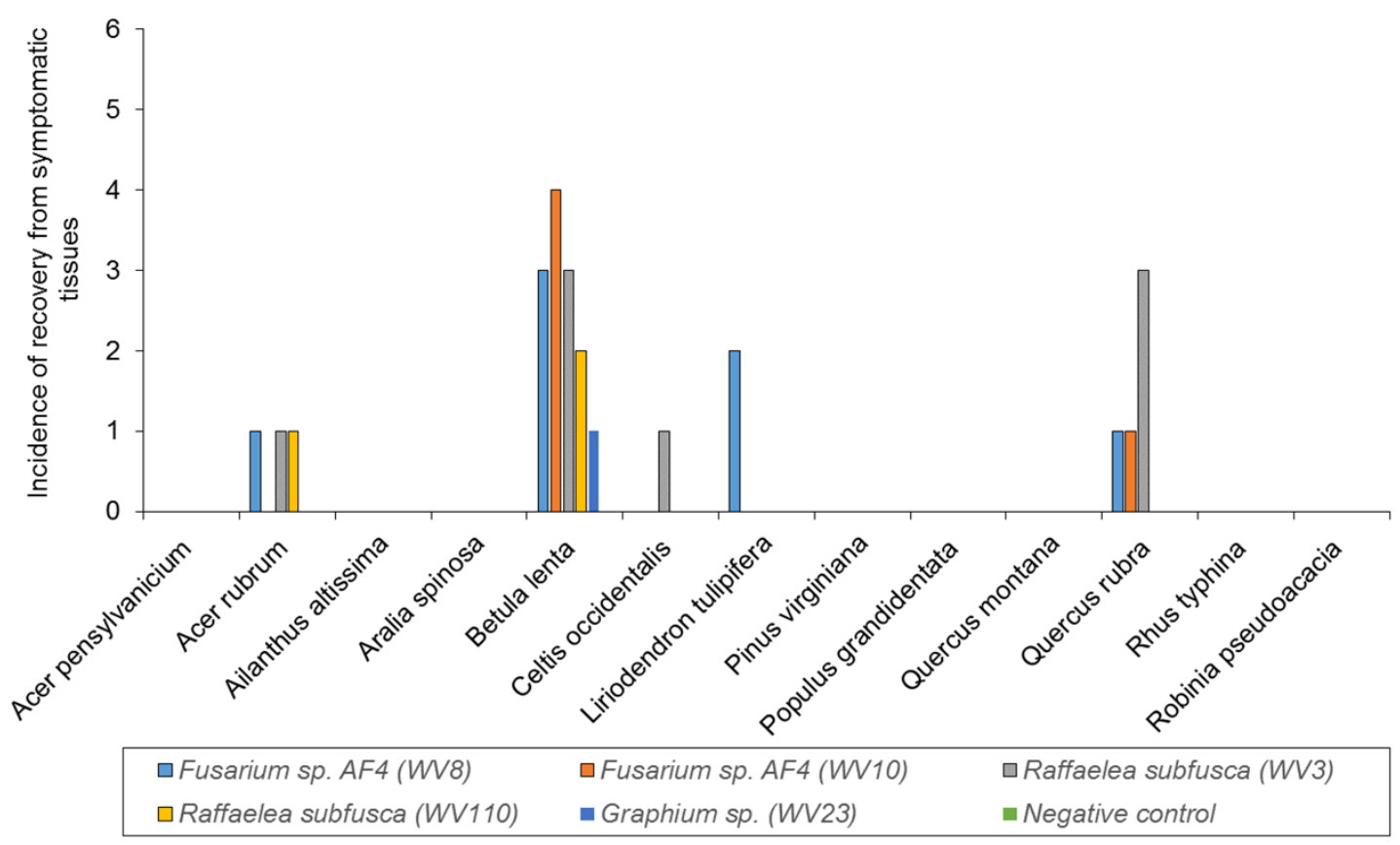

Figure. 7. Incidence of recovery of inoculated fungi across treatments and tree hosts 3.5 moths post-inoculation. 

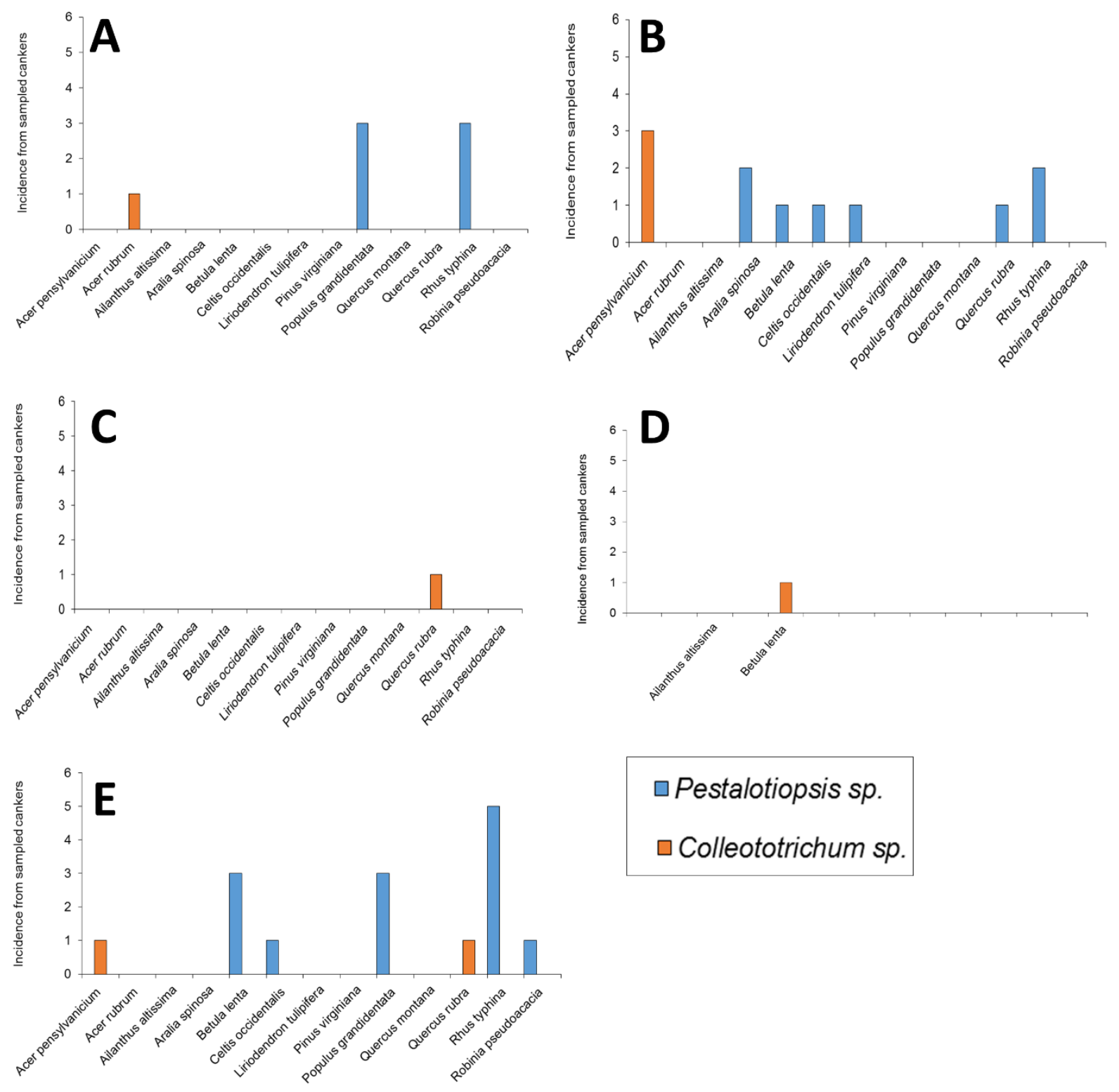

$$
\begin{aligned}
& \square \text { Pestalotiopsis sp. } \\
& \square \text { Colleototrichum sp. }
\end{aligned}
$$

Figure 8. Incidence of recovery of un-inoculated fungal plant pathogens from symptomatic tissues 3.5 months post-inoculation. 

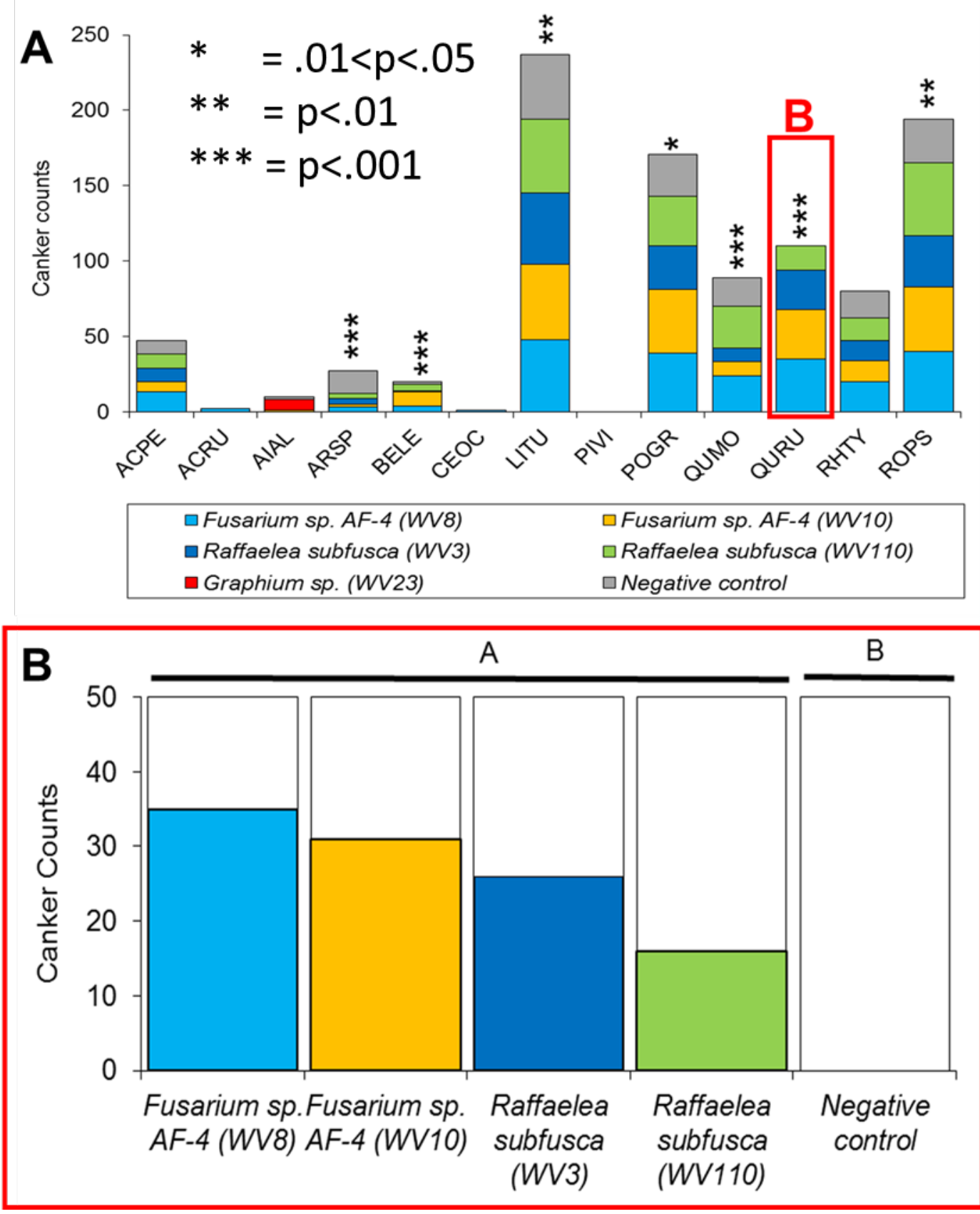

Figure 9. A) Canker incidence across all species and treatments. Significance values based on differences between treatments within an individual species. B) Only northern red oak showed significant differences between all treatments and control. 


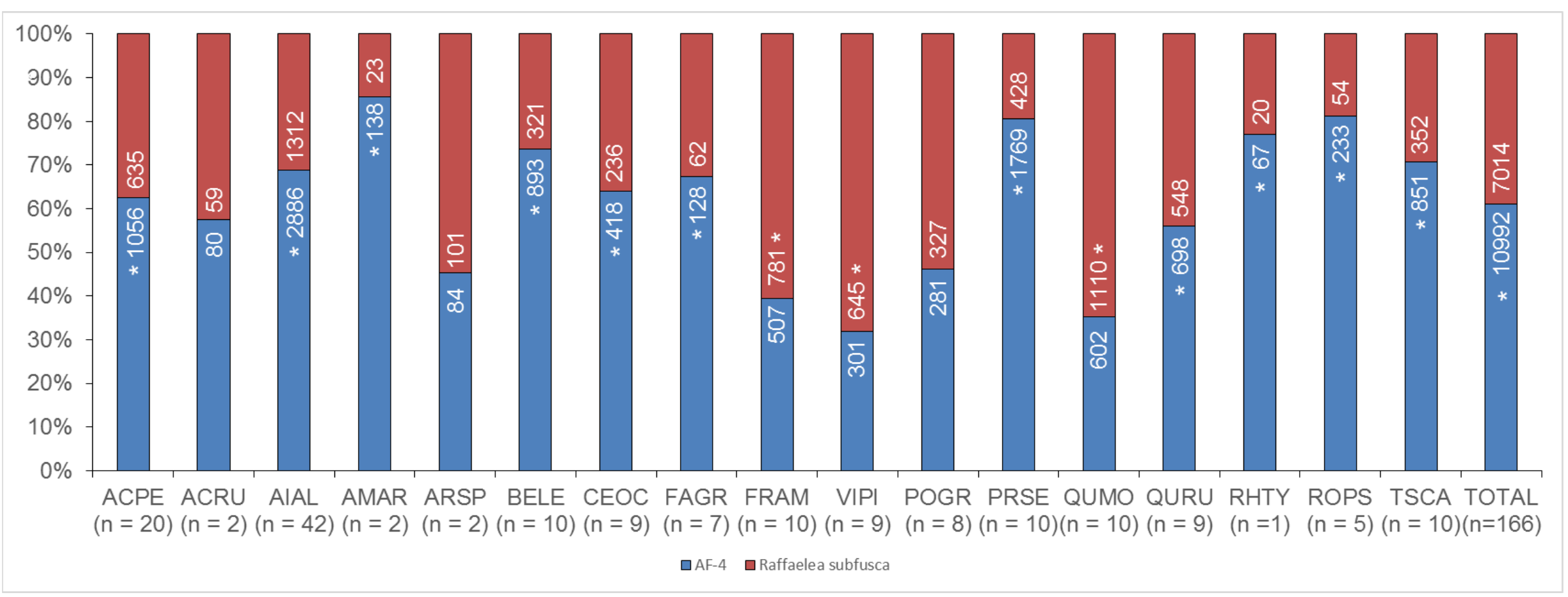

Figure. 10. Total number of AF-4 and Raffaelea subfusca CFUs recovered from all macerated heads from each tree host species. * Indicates a significant difference between the two fungal CFU counts within that host, with the more abundant fungal species containing the * within the bar of its color. 
Table 1. Stain IDs and concentrations/volumes used for fungi used in pathogenicity testing

\begin{tabular}{lcccc}
\hline & $\begin{array}{l}\text { Inoculum } \\
\text { concentratio }\end{array}$ & $\begin{array}{l}\text { Inoculu } \\
\text { m vol. / } \\
\text { Fungal ID }\end{array}$ & $\begin{array}{l}\text { Avg. } \\
\text { conc. / } \\
\mathbf{2 0} \mathbf{~} \mathbf{L} 3 \\
\text { Isolate }\end{array}$ \\
\hline Fusarium sp. AF-4 & WV8 & $1.2 \times 10^{\wedge} 6$ & $20 \mu \mathrm{L}$ & 6800 \\
Fusarium sp. AF-4 & WV10 & $1.55 \times 10^{\wedge} 6$ & $20 \mu \mathrm{L}$ & 7133 \\
Raffaelea subfusca & WV3 & $1.65 \times 10^{\wedge} 6$ & $20 \mu \mathrm{L}$ & 21600 \\
Raffaelea subfusca & WV110 & $1.5 \times 10^{\wedge} 6$ & $20 \mu \mathrm{L}$ & 18667 \\
Graphium sp. \#1 & WV23 & $1.4 \times 10^{\wedge} 6$ & $20 \mu \mathrm{L}$ & 16533 \\
\hline
\end{tabular}


Table 2. Species, diameter, and pre-inoculation health status of trees used pathogenicity field inoculations

\begin{tabular}{|c|c|c|c|c|}
\hline Tree species & $\begin{array}{l}\text { Mean d.b.h. (cm, } \\
\text { range) }\end{array}$ & $\begin{array}{c}\text { Pre-inoc. mean } \\
\text { crown back (\%) }\end{array}$ & Location & $\begin{array}{c}\text { Date of } \\
\text { inoculation }\end{array}$ \\
\hline Acer pensylvanicum & $5.7(6.8-10)$ & $\overline{1}$ & $\begin{array}{l}\text { Copper's Rock } \\
\text { State Forest, } \\
\text { Bruceton Milles, } \\
\text { WV }\end{array}$ & $5 / 19 / 2016$ \\
\hline Acer rubrum & $14.8(18.3-10)$ & 2 & $\begin{array}{l}\text { WVU Research } \\
\text { Forest, Bruceton } \\
\text { Mills, WV }\end{array}$ & $5 / 19 / 2016$ \\
\hline Ailanthus altissima & $6.8(6.4-35)$ & 17 & $\begin{array}{l}\text { Department of } \\
\text { Highways lands, } \\
\text { Fairmont, WV }\end{array}$ & $6 / 12 / 2016$ \\
\hline Aralia spinosa & $4.6(7.2-0)$ & 0 & $\begin{array}{l}\text { WVU Research } \\
\text { Forest, Bruceton } \\
\text { Mills, WV }\end{array}$ & $5 / 20 / 2016$ \\
\hline Betula lenta & $13.5(10.7-5)$ & 0 & $\begin{array}{l}\text { WVU Research } \\
\text { Forest, Bruceton } \\
\text { Mills, WV }\end{array}$ & $5 / 19 / 2016$ \\
\hline Celtis occidentalis & $18(38.8-20)$ & 7 & $\begin{array}{l}\text { WVU Evansdale } \\
\text { campus woodlot }\end{array}$ & $5 / 20 / 2016$ \\
\hline Liriodendron tulipifera & $12.6(11.1-10)$ & 3 & $\begin{array}{l}\text { WVU Research } \\
\text { Forest, Bruceton } \\
\text { Mills, WV }\end{array}$ & $5 / 20 / 2016$ \\
\hline Pinus virginiana & $15.5(32.9-20)$ & 2 & $\begin{array}{l}\text { Mountwood } \\
\text { County Park, } \\
\text { Waverly, WV }\end{array}$ & $5 / 21 / 2016$ \\
\hline Populus grandidentata & $17.3(13.5-30)$ & 9 & $\begin{array}{l}\text { WVU Research } \\
\text { Forest, Bruceton } \\
\text { Mills, WV }\end{array}$ & $5 / 20 / 2016$ \\
\hline Quercus montana & $17.9(13-15)$ & 3 & $\begin{array}{l}\text { WVU Research } \\
\text { Forest, Bruceton } \\
\text { Mills, WV }\end{array}$ & $5 / 20 / 2016$ \\
\hline Quercus rubra & $7.9(11.4-50)$ & 9 & $\begin{array}{l}\text { WVU Research } \\
\text { Forest, Bruceton } \\
\text { Mills, WV }\end{array}$ & $5 / 19 / 2016$ \\
\hline Rhus typhina & $14.3(8.1-15)$ & 2 & $\begin{array}{l}\text { WVU Research } \\
\text { Forest, Bruceton } \\
\text { Mills, WV }\end{array}$ & $5 / 20 / 2016$ \\
\hline Robinia pseudoacacia & $14.3(17.1-0)$ & 0 & $\begin{array}{l}\text { WVU Research } \\
\text { Forest, Bruceton } \\
\text { Mills, WV }\end{array}$ & $5 / 20 / 2016$ \\
\hline
\end{tabular}


Table 3. Fungal treatment inoculation and sampling scheme across all tested hosts

\begin{tabular}{|c|c|c|}
\hline Sampling scheme & Trees & $\begin{array}{l}\text { mber of } \\
\text { Inoculation } \\
\text { sites }\end{array}$ \\
\hline Trees inoculated & 345 & $\begin{array}{c}3450 \\
\text { (10/tree) }\end{array}$ \\
\hline Inoculation sites visualized & $339 *$ & $\begin{array}{c}3390 \\
\text { (10/tree) }\end{array}$ \\
\hline Destructively sampled & 138 & $\begin{array}{c}1380 \\
\text { (10/tree) }\end{array}$ \\
\hline Micorsampled for reisolation & 41 & $\begin{array}{c}410 \\
\text { (3/tree) }\end{array}$ \\
\hline Target fungi recovered and retained for ID & $13+$ & 24 \\
\hline
\end{tabular}


Table 4. Confirmed tree hosts of Euwallacea validus and symtpoms and signs associated with their infestation

\begin{tabular}{|c|c|c|c|c|c|c|c|c|}
\hline Latin Name & Common Name & $\begin{array}{c}\text { Abbreviatio } \\
\mathbf{n}\end{array}$ & $\begin{array}{c}\text { Source } \\
\text { Location }\end{array}$ & $\begin{array}{c}\text { Observed } \\
\text { Reproductiv } \\
\text { e Host for } \\
\text { Beetle }\end{array}$ & $\begin{array}{l}\text { Observe } \\
\text { d in } \\
\text { Living } \\
\text { Trees }\end{array}$ & $\begin{array}{c}\text { Adult } \\
\text { density }\end{array}$ & $\begin{array}{c}\text { Bark } \\
\text { symptom } \\
\text { s from } E . \\
\text { validus } \\
\text { attacks }\end{array}$ & $\begin{array}{c}\text { Gallery } \\
\text { Morpholog } \\
\text { y }\end{array}$ \\
\hline Acer pensylvanicum & Striped Maple & ACPE & $\begin{array}{l}\text { BM, } \\
\text { BSF2 }\end{array}$ & YES & YES & High & - & Forked \\
\hline Acer rubrum & Red Maple & ACRU & $\mathrm{BM}$ & NO & YES & Low & - & Forked \\
\hline Ailanthus altissima & Tree-of-heaven & AIAL & $\begin{array}{c}\text { LV, BM, } \\
\text { WVU EC, } \\
\text { TN, }\end{array}$ & YES & YES & High & Gumming & Forked \\
\hline Amelanchier arborea & $\begin{array}{l}\text { Common } \\
\text { Serviceberry }\end{array}$ & AMAR & PAND & $\mathrm{NO}$ & YES & Low & - & - \\
\hline Aralia spinosa & Devil's Walkingstick & ARSP & RLK3 & NO & NO & Low & - & Forked \\
\hline Betula lenta & Black Birch & BELE & $\mathrm{BM}$ & NO & YES & Low & $\begin{array}{c}\text { active } \\
\text { Neonectri } \\
\text { a cankers }\end{array}$ & Straight \\
\hline Celtis occidentalis & Hackberry & CEOC & WVU EC & NO & NO & Low & - & Forked \\
\hline Fagus grandifolia & American Beech & FAGR & Hocking & $\mathrm{NO}$ & NO & High & - & Forked \\
\hline Fraxinus americana & White Ash & FRAM & WVU EC & NO & NO & Low & - & Forked \\
\hline $\begin{array}{l}\text { Liriodendron } \\
\text { tulipifera }\end{array}$ & Tulip Poplar & LITU & SGL1 & YES & YES & $\begin{array}{c}\text { Moderat } \\
\text { e }\end{array}$ & $\begin{array}{l}\text { Weeping } \\
\text { spots }\end{array}$ & Forked \\
\hline Pinus virginiana & Virginia Pine & VIPI & GHFG & YES & YES & $\begin{array}{c}\text { Moderat } \\
\mathrm{e}\end{array}$ & - & Forked \\
\hline $\begin{array}{l}\text { Populus } \\
\text { grandidentata }\end{array}$ & Big-tooth Aspen & POGR & MSF3-4 & YES & YES & High & - & Forked \\
\hline Prunus serotina & Black cherry & PRSE & GA & NO & NO & $\begin{array}{c}\text { Moderat } \\
\mathrm{e}\end{array}$ & - & Under bark \\
\hline Quercus montana & Chestnut Oak & QUMO & $\mathrm{BM}$ & YES & YES & Low & - & Bark only \\
\hline Quercus rubra & Northern Red Oak & QURU & $\mathrm{BM}$ & NO & YES & Low & - & Bark only \\
\hline Rhus typhina & Staghorn Sumac & RHTY & SGL1 & NO & YES & Low & Gumming & Forked \\
\hline
\end{tabular}




\begin{tabular}{|c|c|c|c|c|c|c|c|c|}
\hline Robinia pseudoacacia & Black Locust & ROPS & SGL1 & NO & NO & Low & $\begin{array}{c}\text { old } \\
\text { cankers }\end{array}$ & Straight \\
\hline Tsuga canadensis & Eastern Hemlock & TSCA & Hocking & NO & $\mathrm{NO}$ & High & - & Forked \\
\hline
\end{tabular}


Table 5. Canker incidence, mean cambial streaking, recovery of inoculated fungus, and susceptibility status for six treatments spanning thirteen tree species

\begin{tabular}{|c|c|c|c|c|c|c|}
\hline \multirow[b]{2}{*}{ Plant Host } & \multirow[b]{2}{*}{ Fungal Treatment } & \multirow[b]{2}{*}{$\begin{array}{c}\text { Canker } \\
\text { Incidence }\end{array}$} & \multirow{2}{*}{$\begin{array}{c}\text { Mean } \\
\text { cambial } \\
\text { streaking }\end{array}$} & \multicolumn{3}{|c|}{ Recovery of Target Fungus based on } \\
\hline & & & & $\begin{array}{c}\text { Culture } \\
\text { morphology }\end{array}$ & $\begin{array}{c}\text { Spore } \\
\text { Morphology }\end{array}$ & $\begin{array}{c}\text { DNA } \\
\text { sequencing }\end{array}$ \\
\hline Acer pensylvanicium & Fusarium sp. AF-4 (WV8) & $13 / 50$ & 97.575 & $0 / 6$ & $\mathrm{n} / \mathrm{a}$ & NO \\
\hline Acer pensylvanicium & Fusarium sp. AF-4 (WV10) & $7 / 50$ & 85.475 & $0 / 6$ & $\mathrm{n} / \mathrm{a}$ & NO \\
\hline Acer pensylvanicium & Negative control & $9 / 50$ & 73.45 & $\mathrm{n} / \mathrm{a}$ & $\mathrm{n} / \mathrm{a}$ & NO \\
\hline Acer pensylvanicium & Raffaelea subfusca (WV110) & $9 / 50$ & 47.31667 & $0 / 6$ & $\mathrm{n} / \mathrm{a}$ & NO \\
\hline Acer pensylvanicium & Raffaelea subfusca (WV3) & $9 / 50$ & 38.625 & $0 / 6$ & $\mathrm{n} / \mathrm{a}$ & NO \\
\hline Acer rubrum & Fusarium sp. AF-4 (WV8) & $2 / 50$ & 284.125 & $4 / 6$ & $1 / 4$ & YES \\
\hline Acer rubrum & Fusarium sp. AF-4 (WV10) & $0 / 50$ & 104.175 & $3 / 6$ & $0 / 6$ & NO \\
\hline Acer rubrum & Negative control & $0 / 50$ & 78.3 & $\mathrm{n} / \mathrm{a}$ & $\mathrm{n} / \mathrm{a}$ & NO \\
\hline Acer rubrum & Raffaelea subfusca (WV110) & $0 / 50$ & 165.925 & $1 / 6$ & $\mathrm{n} / \mathrm{a}$ & NO \\
\hline Acer rubrum & Raffaelea subfusca (WV3) & $0 / 50$ & 62.575 & $1 / 6$ & $\mathrm{n} / \mathrm{a}$ & YES \\
\hline Ailanthus altissima & Fusarium sp. AF-4 (WV8) & $0 / 50$ & 862.375 & $0 / 6$ & $\mathrm{n} / \mathrm{a}$ & NO \\
\hline Ailanthus altissima & Fusarium sp. AF-4 (WV10) & $1 / 50$ & 812.675 & $0 / 6$ & $\mathrm{n} / \mathrm{a}$ & NO \\
\hline Ailanthus altissima & Negative control & $2 / 50$ & 687.15 & $\mathrm{n} / \mathrm{a}$ & $\mathrm{n} / \mathrm{a}$ & NO \\
\hline Ailanthus altissima & Raffaelea subfusca (WV110) & $0 / 50$ & 751.175 & $0 / 6$ & $\mathrm{n} / \mathrm{a}$ & NO \\
\hline Ailanthus altissima & Raffaelea subfusca (WV3) & $0 / 50$ & 517.225 & $0 / 6$ & $\mathrm{n} / \mathrm{a}$ & NO \\
\hline Ailanthus altissima & Graphium sp. \#1 (WV23) & $7 / 50$ & 530.2 & $0 / 6$ & $\mathrm{n} / \mathrm{a}$ & NO \\
\hline Aralia spinosa & Fusarium sp. AF-4 (WV8) & $3 / 50$ & 181.375 & $0 / 6$ & $\mathrm{n} / \mathrm{a}$ & NO \\
\hline Aralia spinosa & Fusarium sp. AF-4 (WV10) & $2 / 50$ & 157.025 & $0 / 6$ & $\mathrm{n} / \mathrm{a}$ & NO \\
\hline Aralia spinosa & Negative control & $15 / 50$ & 124.9 & $\mathrm{n} / \mathrm{a}$ & $\mathrm{n} / \mathrm{a}$ & NO \\
\hline Aralia spinosa & Raffaelea subfusca (WV110) & $3 / 50$ & 100.325 & $0 / 6$ & $\mathrm{n} / \mathrm{a}$ & YES \\
\hline Aralia spinosa & Raffaelea subfusca (WV3) & $4 / 50$ & 257.55 & $0 / 6$ & $\mathrm{n} / \mathrm{a}$ & NO \\
\hline Betula lenta & Fusarium sp. AF-4 (WV8) & $4 / 50$ & 154.8 & $3 / 6$ & $3 / 3$ & YES \\
\hline Betula lenta & Fusarium sp. AF-4 (WV10) & $9 / 50$ & 183 & $5 / 6$ & $4 / 6$ & YES \\
\hline Betula lenta & Negative control & $2 / 50$ & 145.3 & $\mathrm{n} / \mathrm{a}$ & $\mathrm{n} / \mathrm{a}$ & NO \\
\hline Betula lenta & Raffaelea subfusca (WV110) & $4 / 50$ & 122.825 & $3 / 6$ & $\mathrm{n} / \mathrm{a}$ & NO \\
\hline
\end{tabular}


Betula lenta

Betula lenta

Celtis occidentalis

Celtis occidentalis

Celtis occidentalis

Celtis occidentalis

Celtis occidentalis

Liriodendron

tulipifera

Liriodendron

tulipifera

Liriodendron

tulipifera

Liriodendron

tulipifera

Liriodendron

tulipifera

Pinus virginiana

Pinus virginiana

Pinus virginiana

Pinus virginiana

Pinus virginiana

Populus

grandidentata

Populus

grandidentata

Populus

grandidentata

Populus

grandidentata

Populus

grandidentata

Quercus montana

Quercus montana
Graphium sp. \#1 (WV23)

Fusarium sp. AF-4 (WV8) $1 / 50$

Fusarium sp. AF-4 (WV10) 0/50

Negative control $\quad 0 / 50$

Raffaelea subfusca (WV110) 0/50

Raffaelea subfusca (WV3) 0/50

$109.6 \quad 2 / 6$

$140.5 \quad 1 / 6$

$588.75 \quad 0 / 6$

$250.825 \quad 1 / 6$

$46.875 \quad \mathrm{n} / \mathrm{a}$

$35.15 \quad 0 / 6$

$37.425 \quad 1 / 6$

Fusarium sp. AF-4 (WV8) $\quad$ 48/50

208.175

$2 / 6$

Fusarium sp. AF-4 (WV10)

486.95

$3 / 6$

Negative control

$50 / 50$

168.275

$\mathrm{n} / \mathrm{a}$

110.225

$0 / 6$

Raffaelea subfusca (WV110)

$49 / 50$

162.15

Raffaelea subfusca (WV3)

$47 / 50$

48.55

52.575

Fusarium sp. AF-4 (WV10)

$0 / 50$

$0 / 50$

$0 / 50$

Negative control

49.575

40.2

61.5

$0 / 50$

Raffaelea subfusca (WV3)

Fusarium sp. AF-4 (WV8)

$39 / 50$

210.925

$42 / 50$

376.2

$28 / 50$

518.05

$33 / 50$

164.925

112.3

Raffaelea subfusca (WV3)

$29 / 50$

$24 / 50$

148.55

Fusarium sp. AF-4 (WV10)

9/50

204.9875

\section{$0 / 6$}

$0 / 6$

0/6

n/a

0/6

0/6

$\mathrm{n} / \mathrm{a}$

YES

YES

NO

NO

NO

NO

NO

YES

NO

NO

NO

NO

NO

NO

NO

NO

NO

NO

NO

NO

NO

NO

$\mathrm{n} / \mathrm{a}$

NO

$\mathrm{n} / \mathrm{a}$

NO 


\begin{tabular}{|c|c|c|c|c|c|c|}
\hline Quercus montana & Negative control & $19 / 50$ & 56.1 & $\mathrm{n} / \mathrm{a}$ & $\mathrm{n} / \mathrm{a}$ & NO \\
\hline Quercus montana & Raffaelea subfusca (WV110) & $28 / 50$ & 217.3 & $0 / 6$ & $\mathrm{n} / \mathrm{a}$ & NO \\
\hline Quercus montana & Raffaelea subfusca (WV3) & $9 / 50$ & 291.225 & $0 / 6$ & $\mathrm{n} / \mathrm{a}$ & NO \\
\hline Quercus rubra & Fusarium sp. AF-4 (WV8) & $35 / 50$ & 202.35 & $1 / 6$ & $1 / 1$ & YES \\
\hline Quercus rubra & Fusarium sp. AF-4 (WV10) & $33 / 50$ & 212.2 & $1 / 6$ & $1 / 1$ & YES \\
\hline Quercus rubra & Negative control & $0 / 50$ & 60.55 & $\mathrm{n} / \mathrm{a}$ & $\mathrm{n} / \mathrm{a}$ & NO \\
\hline Quercus rubra & Raffaelea subfusca (WV110) & $16 / 50$ & 51.125 & $0 / 6$ & $\mathrm{n} / \mathrm{a}$ & NO \\
\hline Quercus rubra & Raffaelea subfusca (WV3) & $26 / 50$ & 110.825 & $3 / 6$ & $\mathrm{n} / \mathrm{a}$ & YES \\
\hline Rhus typhina & Fusarium sp. AF-4 (WV8) & $20 / 50$ & 769.35 & $0 / 6$ & $\mathrm{n} / \mathrm{a}$ & NO \\
\hline Rhus typhina & Fusarium sp. AF-4 (WV10) & $14 / 50$ & 1212.25 & $0 / 6$ & $\mathrm{n} / \mathrm{a}$ & NO \\
\hline Rhus typhina & Negative control & $18 / 50$ & 199.175 & $\mathrm{n} / \mathrm{a}$ & $\mathrm{n} / \mathrm{a}$ & NO \\
\hline Rhus typhina & Raffaelea subfusca (WV110) & $15 / 50$ & 233.775 & $0 / 6$ & $\mathrm{n} / \mathrm{a}$ & NO \\
\hline $\begin{array}{l}\text { Rhus typhina } \\
\text { Robinia }\end{array}$ & Raffaelea subfusca (WV3) & $13 / 50$ & 307.8 & $0 / 6$ & $\mathrm{n} / \mathrm{a}$ & NO \\
\hline $\begin{array}{l}\text { pseudoacacia } \\
\text { Robinia }\end{array}$ & Fusarium sp. AF-4 (WV8) & $40 / 50$ & 106 & $0 / 6$ & $\mathrm{n} / \mathrm{a}$ & NO \\
\hline $\begin{array}{l}\text { pseudoacacia } \\
\text { Robinia }\end{array}$ & Fusarium sp. AF-4 (WV10) & $43 / 50$ & 186.4 & $0 / 6$ & $\mathrm{n} / \mathrm{a}$ & NO \\
\hline $\begin{array}{l}\text { pseudoacacia } \\
\text { Robinia }\end{array}$ & Negative control & $29 / 50$ & 87.6 & $\mathrm{n} / \mathrm{a}$ & $\mathrm{n} / \mathrm{a}$ & NO \\
\hline $\begin{array}{l}\text { pseudoacacia } \\
\text { Robinia }\end{array}$ & Raffaelea subfusca (WV110) & $48 / 50$ & 169.8 & $0 / 6$ & $\mathrm{n} / \mathrm{a}$ & NO \\
\hline pseudoacacia & Raffaelea subfusca (WV3) & $34 / 50$ & 73.425 & $0 / 6$ & $\mathrm{n} / \mathrm{a}$ & NO \\
\hline
\end{tabular}


Table 6. Reisolated fungi identified by sequencing of the (ITS) region

\begin{tabular}{|c|c|c|c|c|c|}
\hline In \# & Tree Species & Treatment & & Putative Species & Sequence Confirmed Species \\
\hline In01 & ACRU & & 1 & Colletotrichum sp. & Colletotrichum acutatum \\
\hline In02 & MISSING & MISSING & & Colletotrichum sp. & Colletotrichum acutatum \\
\hline In03 & RHTY & & 2 & Colletotrichum sp. & Fusarium lateritium \\
\hline In04 & BELE & & 5 & Colletotrichum sp. & Colletotrichum acutatum \\
\hline In05 & QURU & & 7 & Colletotrichum sp. & Colletotrichum acutatum \\
\hline In06 & MISSING & MISSING & & Pestalotiopsis sp. & Pestalotiopsis cocculi \\
\hline In07 & BELE & & 7 & Pestalotiopsis sp. & Diaporthe eres \\
\hline In08 & ACRU & & 2 & Pestalotiopsis sp. & Cytospora sp. \\
\hline In09 & CEOC & & 7 & Pestalotiopsis sp. & Pestalotiopsis vismiae \\
\hline In10 & ROPS & & 7 & Pestalotiopsis sp. & Pestalotiopsis maculans \\
\hline In11 & LITU & & 2 & Pestalotiopsis sp. & Diaporthe eres \\
\hline In12 & MISSING & MISSING & & Pestalotiopsis sp. & Pestalotiopsis cocculi \\
\hline In13 & ACRU & & 1 & Fusarium sp. & Fusarium solani isolate \\
\hline In14 & ACRU & & 1 & Fusarium sp. & Fusarium solani strain NRRL \\
\hline In15 & BELE & & 7 & Fusarium sp. & Fusarium solani isolate FS0803 \\
\hline In16 & LITU & & 2 & Fusarium sp. & Fusarium solani isolate FS0801 \\
\hline In17 & LITU & & 2 & Fusarium sp. & Fusarium solani isolate FS0801 \\
\hline In18 & LITU & & 2 & Fusarium sp. & Fusarium solani isolate FS0801 \\
\hline In19 & CEOC & & 7 & Fusarium sp. & MISSING \\
\hline In20 & CEOC & & 7 & Fusarium sp. & MISSING \\
\hline In21 & CEOC & & 7 & Fusarium sp. & Fusarium neocosmosporiellum \\
\hline In22 & CEOC & & 7 & Fusarium sp. & Neocosmospora vasinfecta \\
\hline In23 & LITU & & 2 & Fusarium sp. & Fusarium solani isolate FS0801 \\
\hline In24 & BELE & & 5 & Fusarium sp. & Fusarium solani strain DE28 \\
\hline In25 & QURU & & 1 & AF-4 & $\mathrm{AF}-4$ \\
\hline In26 & BELE & & 2 & AF-4 & $\mathrm{AF}-4$ \\
\hline In27 & ACRU & & 1 & AF-4 & AF-4 \\
\hline In28 & LITU & & 1 & AF-4 & AF-4 \\
\hline
\end{tabular}




$\begin{array}{ll}\text { In29 } & \text { BELE } \\ \text { In30 } & \text { BELE } \\ \text { In31 } & \text { BELE } \\ \text { In32 } & \text { BELE } \\ \text { In33 } & \text { QURU } \\ \text { In34 } & \text { LITU } \\ \text { In35 } & \text { BELE } \\ \text { In36 } & \text { BELE } \\ \text { In37 } & \text { QURU } \\ \text { In38 } & \text { QURU } \\ \text { In39 } & \text { CEOC } \\ \text { In40 } & \text { BELE } \\ \text { In41 } & \text { BELE } \\ \text { In42 } & \text { QURU } \\ \text { In43 } & \text { BELE } \\ \text { In44 } & \text { ACRU } \\ \text { In45 } & \text { BELE } \\ \text { In46 } & \text { QURU } \\ \text { In47 } & \text { QURU } \\ \text { In48 } & \text { QURU } \\ \text { In49 } & \text { QURU } \\ \text { In50 } & \text { QURU } \\ \text { In51 } & \text { QURU } \\ \text { In52 } & \text { BELE } \\ \text { In53 } & \text { RHTY } \\ \text { In54 } & \text { CEOC } \\ \text { In55 } & \text { QURU } \\ \text { In56 } & \text { PIVI } \\ \text { In57 } & \text { PIVI } \\ \text { In58 } & \text { RHTY } \\ \text { In59 } & \text { ACRU }\end{array}$

$\begin{array}{lll}1 & \text { AF-4 } \\ 1 & \text { AF-4 } \\ 1 & \text { AF-4 } \\ 2 & \text { AF-4 } \\ 2 & \text { AF-4 } \\ 1 & \text { AF-4 } \\ 2 & \text { AF-4 } \\ 2 & \text { AF-4 } \\ 3 & \text { Raffaelea subfusca } \\ 3 & \text { Raffaelea subfusca } \\ 3 & \text { Raffaelea subfusca } \\ 3 & \text { Raffaelea subfusca } \\ 4 & \text { Raffaelea subfusca } \\ 3 & \text { Raffaelea subfusca } \\ 3 & \text { Raffaelea subfusca } \\ 3 & \text { Raffaelea subfusca } \\ 4 & \text { Raffaelea subfusca } \\ 7 & \text { Unknown pink consistant } \\ 2 & \text { Unknown } \\ 2 & \text { Unknown } \\ 2 & \text { Unknown pink consistant } \\ 7 & \text { Unknown } \\ 2 & \text { Unknown } \\ & & \text { Unknown } \\ 7 & \text { Unknown } \\ 1 & \text { Unknown basido } \\ 3 & \text { Unknown basido } \\ 4 & \text { Penicillium sp. } \\ 1 & \text { Penicillium sp. } \\ 7 & \text { Penicillium sp. } \\ 2 & \text { Penicillium sp. } \\ & \end{array}$

AF-4

AF-4

AF-4

AF-4

AF-4

AF-4

AF-4

AF-4

Raffaelea subfusca

Hanseniaspora uvarum

MISSING

MISSING

Valsa pini

Raffaelea subfusca

Raffaelea subfusca

Raffaelea subfusca

MISSING

Ascocoryne sarcoides

MISSING

MISSING

MISSING

Ascocoryne sarcoides

Mucorales sp.

Pochonia bulbillosa

Stereum complicatum

Biscogniauxia formosana

Uncultured Ceratobasidiaceae clone

Penicillium glabrum

Penicillium glabrum

Penicillium sp.

Penicillium glabrum 


\begin{tabular}{lllll} 
In60 & ACRU & 3 & Penicillium sp. & Penicillium glabrum \\
In61 & ACPE & 7 & Trichoderma sp. & Trichoderma lixii \\
In62 & ARSP & 7 & Trichoderma sp. & Trichoderma harzianum \\
In63 & RHTY & 2 & Trichoderma sp. & Trichoderma atroviride \\
In64 & ACRU & 2 & Unknown & Trichoderma sp. strain SPH2 \\
In65 & ACRU & 2 & Unknown & MISSING \\
In66 & QURU & 1 & Unknown consistant & Dothideomycetes sp. genotype 390 \\
In67 & LITU & 7 & Unknown very consistant & \\
& & 7 & gray fuzzy on LITU & Leptosphaeria sp. \\
In68 & LITU & & Unknown very consistant & Leptosphaeria sp \\
In69 & LITU & 1 & gray fuzzy on LITU & \\
In70 & BELE & 7 & Unknown very consistant & \\
In71 & ARSP & 7 gray fuzzy on LITU & Leptosphaeria sp. \\
In72 & PIVI & 5 & Graphium sp. & Graphium euwallaceae isolate \\
\hline
\end{tabular}




\title{
Chapter 3: Fusarium symbiont diversity and fidelity among Euwallacea spp.
}

\section{in their native and invaded ranges}

\author{
Abstract
}

Euwallacea ambrosia beetles vector members of the Ambrosia Fusarium Clade (AFC), a monophyletic clade within the Fusarium solani species complex (FSSC). Several EuwallaceaFusarium consortia have been introduced into the U.S. and have caused varying degrees of damage to orchard, landscape, and forest trees. Recently, PCR multiplexes were developed to discriminate closely related AFC symbionts present in the U.S. Such methods have opened the door for widespread molecular surveillance. This includes testing whether fusaria differ between the native / invaded ranges of these beetles. In addition, such tools can better track AFC members as the ranges of two or more Euwallacea spp. overlap within invaded regions, which has been confirmed in both the eastern and western U.S. To this end, 51 fusaria recovered from 5 Euwallacea spp. within their native range in China, Taiwan, South Korea, and Vietnam as well as 100 fusaria from each of two Euwallacea spp. (E. validus and E. interjectus) already present in the U.S. were subjected to multiplex PCR assays. Results confirmed fidelity between $E$. validus and AF-4 in South Korea and the U.S with no evidence of co-cultivation despite the overlap between at least two Euwallacea spp. with distinct AFC lineages in northern GA. E. interjectus from two locations in the U.S., two locations in China, and one location in Taiwan all had unique fungal lineages within the AFC. In Taiwan, E. interjectus is associated with AF-12, the known symbiont of Euwallacea sp. \#5 from San Diego, CA whereas in the Eastern U.S. it is associated with AF-3 and potentially novel AFC members in TX and China. E. denticulus, from one location in China, is associated with AF-6, one of two known symbionts of Euwallacea sp. \#2 from Dade Co., FL, where E. denticulus has been previously, albeit infrequently, reported. 
The remaining E. denticulus AFC members as well as those associated with E. aff. fornicatus in China and an unidentified Euwallacea sp. in Vietnam all likely possess novel AFC lineages. In addition to AFC members, other FSSC isolates were associated with galleries of all five Euwallacea spp. studied, indicating frequent interactions between symbiotic and phytopathogenic FSSC members. Together these results support fungal infidelity among closely related Euwallacea beetles and the potential for novel beetle-fungus combinations that could incite disease.

\section{Introduction}

Since the early 1970’s at least six species of exotic Euwallacea have become established in the United States (Cognato et al. 2015; O’Donnell et al. 2015): E. interjectus (Blandford), E. validus (Eichhoff), E. denticulus (Motschulsky), and three E. fornicatus-like species (Eichhoff) (Atkinson 2016; O’Donnell et al. 2015; Storer et al. 2015). Additional detections of E. interjectus have been previously reported from Texas and Hawaii but these beetles have evaded detection in subsequent trappings possibly indicating failure to establish following their introduction (Cognato et al. 2015).

Euwallacea ambrosia beetles cultivate mutualistic fusaria belonging to monophyletic clade called the Ambrosia Fusarium Clade (AFC) within the Fusarium solani species complex (FSSC), some of which cause a destructive disease known as Fusarium dieback or Fusarium canker on various plant hosts (Eskalen et al. 2013; Kasson et al. 2013; Mendel et al. 2012). The Polyphagous Shot Hole Borer in California and Israel, which farms Fusarium euwallaceae (also known as Fusarium sp. AF-2) S. Freeman, Z. Mendel, T. Aoki \& O’Donnell, has had the greatest impact on landscape and forest trees (Eskalen et al 2013; Freeman et al. 2013). 
The Ambrosia Fusarium Clade (AFC) currently consists of 12 putatively clonal specieslevel lineages (O’Donnell et al. 2015), most of which lack Latin binomials. Instead, lineages are identified with an 'AF' followed by a numerical identifier 1-12 to distinguish the 12 phylogentic species within this clade. Most members of the AFC produce clavate macroconidia rather than the iconic fusiform conidia characteristic of Fusarium, which is thought to be an adaptation for symbiosis (Kasson et al. 2013). A majority of Euwallacea spp. harbor a single Fusarium sp. with two exceptions: Euwallacea sp. \#2 in Florida cultivates two closely related AFC members, Fusarium spp. AF-6 and AF-8 and Euwallacea sp. \#4 from in Sri Lanka cultivates Fusarium ambrosium (AF-1) and Fusarium sp. AF-11 (O’Donnell et al. 2015). Furthermore cophylogenetic analyses suggest Euwallacea and Fusarium phylogenies are largely incongruent, apparently due to the beetles switching fusarial symbionts at least five times during the evolution of this mutualism (O’Donnell et al. 2015).

Until recently, rapid detection and discrimination of Fusarium symbionts was not possible mainly due to difficulty in distinguishing closely related taxa using multi-locus sequence typing (MLST), which often necessitates integration of $>40$ reference sequences to distinguish species (Kasson et al. 2013, O’Donnell et al. 2015). Co-cultivation of closely related AFC members by several Euwallacea spp. coupled with confirmed interspecific hybridization within the AFC also has hampered efforts to identify specific AFC lineages. Recently, PCR multiplexes were developed to discriminate six closely related AFC symbionts established in the U.S. (Short et al. 2017). These PCR-based assays have opened the door for widespread molecular surveillance in settings that previously relied on MLST analysis. This includes testing whether AFC fusaria are maintained as the ranges of two beetles overlap and whether AFC fusaria differ between the native / invaded ranges of these beetles. 
The present study was initiated to (i) test the utility of recently developed multiplex PCRs, to confirm co-cultivation in individual Euwallacea sp. and/or swapping of AFC Fusarium spp. between Euwallacea spp. and (ii) explore Fusarium fidelity within individual Euwallacea spp. across the native and introduced range.

Materials and Methods

Beetle collection, processing, and culture maintenance

Beetles were either extracted or trap-caught using ethanol baits, after which beetles were processed as previously described by Kasson and colleagues (2013). Single colonies were subcultured for DNA extraction and transferred to PDA slants for long term storage as described by Short et al. (2015).

The use of the multiplex primer sets to test for co-cultivation \& fungus switching of Fusarium spp. between Euwallacea spp.

To test whether the geographic co-occurrence of two or more Euwallacea spp. could result in co-cultivation or fungus swapping of closely related AFC fusaria, fungal isolations were screened using a multiplex developed by Short et al. (2017). DNA was extracted from ten single Fusarium colonies for each of ten adult female E. validus extracted from a naturally infested cherry log in Moccasin Creek State Park in Rabun Co., GA where E. validus and E. interjectus are thought to overlap. 
The use of the multiplex primer sets to test for Fusarium fidelity within individual Euwallacea spp. across the native and introduced range

Tests of symbiont fidelity and prevalence were performed both domestically and for beetles collected within the native range of Euwallacea is Southeast Asia. Within their native range in east Asia, 25 Fusarium isolates cultured from live Euwallacea spp. from 2014-2016 were subjected to multiplex PCRs used to identify known Fusarium symbionts of E. fornicatus, E. interjectus, and E. validus. Additional isolates from E. similis were also included since Fusarium spp. have yet to be molecularly confirmed from this species. A total of 25 putative fusaria recovered from 19 Euwallacea beetles collected from China, South Korea, and Taiwan were included. The collection of beetles was morphological identified and included one $E$. denticulus, two E. fornicatus, two E. interjectus and one E. validus from China; six E. interjectus from Taiwan; and five E. validus from South Korea. Beetles were primarily collected from infested wood in China with the exception of E. similis, whereas all but one E. interjectus specimen from Taiwan were trap-caught. Fungal isolations were conducted in the field as previously described (Kasson et al. 2013). Microscopic evaluation of macroconidia morphology was performed for all representative cultures. DNA extractions were performed on pure cultures of putative Fusarium spp. as described above. To confirm their phylogenetic membership to the AFC, a portion of EF1- $\alpha$ was sequenced and queried against NCBI Genbank. Species identities of beetles (sensu Cognato et al. 2015) were molecularly determined by sequencing the cytochrome oxidase gene (CO1), followed by subsequent DNA sequence alignment and phylogenetic analysis as previously described. 
Within the U.S. ten single Fusarium colonies for each of ten adult female E. interjectus extracted from a naturally infested living Mexican Magnolia tree Texas. This population represents a phylogenetically distinct population of E. interjectus that may harbor novel symbionts (Cognato et al. 2015).

Results

The use of the multiplex primer sets to test for co-cultivation \& fungus switching of Fusarium spp. between Euwallacea spp.

One hundred fusaria recovered from ten adult female E. validus extracted from a naturally infested cherry log in Moccasin Creek State Park in Rabun Co., GA were subjected to AF-3 / AF-4 multiplex. Results of the multiplex showed 91 of 100 isolates were AF-4 with clavate macroconidial morphology, generating amplicons of expected size ca. 700 bp. Cultures from the remaining isolates were re-assessed for differences in macroconidial morphology. Following confirmation of clavate macroconidia strains, the nine isolates were then subjected to each of two additional multiplexes, AF-6 / AF-8 and AF-2 / AF-12 to assess whether they aligned with one of the four additional U.S. lineages. All results were negative. These nine isolates were then subcultured to permit a second independent DNA extraction and testing using PCR multiplexes. Results from the AF-3 / AF-4 multiplex on new DNA templates confirmed them as AF-4 amplicons. Together these results indicate a single AFC lineage present in $E$. validus from within the overlapping range of E. validus and E. interjectus. 
EF1- $\alpha$ sequences from two representative isolates, F2-4 and F4-3, aligned with reference sequence Fusarium sp. AF-4 (NRRL 62578), which supports the multiplex results (Fig. 2).

The use of the multiplex primer sets to test for Fusarium fidelity within individual Euwallacea spp. across the native and introduced range

One hundred fusaria recovered from ten adult female $E$. interjectus extracted from a living Mexican magnolia tree located on the grounds of the Peckerwood Arboretum in Hempstead, TX were subjected to AF-3 / AF-4 multiplex since E. interjectus in other parts of the southeastern U.S. has been previously associated with Fusarium sp. AF-3. Results of the multiplex showed 0 of 100 isolates were negative for AF-3 and AF-4, indicating that AF-3 is not conserved across populations in the southeastern U.S. Following morphological comparisons, it was confirmed that nine isolates had fusiform macroconidia while the remaining 91 had clavate macroconidia. Despite differences in morphology both sets of isolates were then subjected to each of two additional multiplexes, AF-6 / AF-8 and AF-2 / AF-12, the results of which were negative.

$E F 1-\alpha$ sequences from two isolates representing each of the two macroconidial morphotypes, Ei73 (clavate) and Ei66 (fusiform) were phylogenetically divergent (Fig. 2). Isolate Ei73 aligned most closely with AF-4 and AF-12 but likely represents a novel species since both multiplexes failed to amplify expected PCR products. Isolate Ei66 was within the FSSC but outside the monophyletic AFC (Fig. 2), grouping closely with other fusiform strains recovered from E. denticulus in China.

A total of 51 fusaria of Asian origin were included in this study including six from Taiwan, four from South Korea, seven from Vietnam, and 34 from China. A maximum of 20 beetles were collected from individual countries and 5 isolates were recovered from single 
beetles but averaged 2 isolates per beetle across the four countries (Table 1). All isolates were subjected to each of three PCR multiplexes.

Five of six isolates recovered from E. interjectus in Taiwan yielded AF-12 amplicons using the AF-2 / AF-12 PCR multiplex (Fig. 3, Table 2). The remaining isolate yielded no amplicons for any of the three multiplex PCR assays. Sequence data for PCR products from two isolates (8648 and 8649) were 100\% and 99\% identical, respectively, to Genbank accession KT835024, which was the initial sequence deposited by Short et al. (2017) in developing these multiplex PCR assays (Table 3). EF1- $\alpha$ sequences from all four isolates were phylogenetically indistinguishable from reference AF-4 strain (Fig 2). EF1- $\alpha$ sequences from all six isolates aligned with reference AF-4 strain despite isolate 8646 not generating amplicons using the lineage-specific PCR assay (Fig 2). Macroconidial morphology was consistent across all isolates with the clavate morphotype characteristics of a majority of AFC members (Fig. 1, 2).

Four isolates recovered from E. validus in South Korea yielded AF-4 amplicons using the AF-3 / AF-4 multiplex (Fig. 3, Table 2). Sequence data for one of these PCR products, isolate 13803, was 100\% identical to Genbank accession KT835021. EF1- $\alpha$ sequences from all four isolates aligned with reference AF-4 strain (Fig 2). Interestingly, strains had either clavate (13803, 13805) or fusiform $(13804,13806)$ macroconidial morphology (Fig. 1, 2).

Seven isolates recovered from an unidentified Euwallacea sp. in Vietnam failed to generate PCR products when subjected to each of the three PCR multiplexes (Table 2). EF1- $\alpha$ sequences were phylogenetically divergent with four falling within the AFC and the remaining three falling outside the AFC but within the FSSC (Fig. 2). All AFC isolates were phylogenetically indistinguishable from the clade that included AF-4 and AF-12 but 3 of four were phylogenetically divergent (Fig 2). Non-AFC members formed a clonal lineage with two 
isolates from China. Interestingly isolates were all separated based on macroconidial morphology with all AFC members having clavate macroconidial and all non-AFC isolates with fusiform macroconidia (Fig. 1,2).

Four Euwallacea spp. (E. fornicatus, E. denticulus, E. interjectus, and E. validus) were recovered in China from which fungal isolates were obtained from either beetles or their galleries and are as follows: nine isolates from E. fornicatus, 12 isolates from E. denticulus, 10 isolates from E. interjectus, and 3 isolates from E. validus (Table 1).

Nine isolates recovered from E. fornicatus failed to generate PCR products when subjected to each of the three PCR multiplexes. EF1- $\alpha$ sequences were phylogenetically divergent with eight falling within the AFC and the remaining isolate falling outside the AFC but within the FSSC (Fig. 2, Table 2). All AFC isolates had clavate macroconidia and were phylogenetically indistinguishable from the clade that included AF-4 and AF-12 despite none of the isolates generating amplicons using either of the two lineage-specific PCR assays (Fig 2). The single non-AFC isolate, LL163, aligned with the Vietnamese strains (Fig. 2).

Five of twelve isolates recovered from E. denticulus from two Chinese Provinces yielded AF-6 amplicons using the AF-6 / AF-8 multiplex (Fig. 3, Table 2). The remaining seven isolates failed to generate PCR products when subjected to each of the three PCR multiplexes. Sequence data for PCR products from two isolates (LL154 and LL155) were 99\% identical to Genbank accession KT835022. EF1- $\alpha$ sequences for the five AF-6 positive strains formed two genealogical exclusive clades on either side of reference strain for AF-6 (NRRL 62591). Similar to the reference strain, all AF-6 positive isolates had fusiform macroconidia (Fig. 2). EF1- $\alpha$ sequences for the remaining seven fusaria were phylogenetically divergent with five falling within the AFC and the remaining isolate falling outside the AFC but within the FSSC (Fig. 2). 
All but one (isolate LL184) of these AFC members and both non-AFC members had fusiform macroconidia (Fig 2). These same five AFC members aligned mostly with the clade containing reference strains for AF-4 and AF-12 with one other strain grouping with a clade containing three AF-6 positive strains from E. denticulus as well as references strains for AF-1, AF-7 through AF-9. The two non-AFC isolates from E. denticulus formed a clade with a single isolate recovered from E. interjectus in Texas (Fig. 2).

Ten isolates recovered from E. interjectus from two Chinese Provinces failed to generate PCR products when subjected to each of the three PCR multiplexes. All AFC isolates had clavate macroconidia and were phylogenetically indistinguishable from AF-4 and AF-12 based on EF1$\alpha$ sequences despite none of the isolates generating amplicons using either of the two lineagespecific PCR assays (Fig 2, Table 2). LL167 aligned with the same clade but was genetically divergent from the other strains.

Three isolates recovered from E. validus galleries in one Chinese Province failed to generate PCR products when subjected to each of the three PCR multiplexes. Based on EF1- $\alpha$ sequence data, all isolates fell outside the AFC but forming a single clade along with Vietnamese fusaria (Fig. 2, Table 2).

\section{Discussion}

The present study sought to resolve the complex relationships between Euwallacea ambrosia beetles and their Fusarium symbionts in both post-invasion forests here in the U.S. as well as in their native habitat in Asia. Results of this study confirmed strict fidelity between Euwallacea validus and its Fusarium sp. AF-4 both in areas where E. validus overlaps the range of E. interjectus in the southeastern U.S. as well as in the native range of Euwallacea in South 
Korea. Differences in macroconidia morphology were observed between the two locations with half of the South Korean isolates with fusiform macrocondia, which has not been previously reported for Fusarium sp. AF-4.

Despite fidelity between E. validus and Fusarium sp. AF-4, the invaded ranges of E. validus and E. interjectus have only recently coalesced in the U.S. (Cognato et al. 2015). It remains unclear if long-term co-occurrence of these two beetle species on common plant hosts might facilitate symbiont swapping (infidelity), co-cultivation, or hybridization in the immediate or distant future. Interestingly, Carrillo and colleagues (2016) found evidence of hybrid AFC members associated with a recent an outbreak of E. nr. fornicatus on avocado in Homestead, FL that resulted in branch dieback and mortality not previously seen in these areas where Fusarium AF-6 and AF-8 are well established. Use of Fusarium AF-6 / AF-8 multiplexes on several of these isolates failed to establish parentage for these isolates possibly indicating a parent outside the AFC (unpublished data).

Over the last two decades a number of emerging hybrid fungal pathogens of trees have been detected among the previously introduced fungal pathogens including fungi involved with bark beetle-vectored Dutch elm disease and poplar leaf rust, which are thought to have arisen through secondary contact events between formerly geographically separated, closely related fungal species and sub-species (Brasier 2000). Perhaps the biggest concern regarding these hybrids is the fact that some of these recombinant pathogens show increased aggressiveness on previously known hosts as well as the ability to exploit and kill new plant hosts (Brasier 2000), which has also been observed in agricultural systems (Inderbitzin et al. 2011). Following the discovery of hybrid AFC fusaria from Euwallacea spp. within their presumed center of origin in India and Sri Lanka (Kasson et al. 2013), concerns that these fungi would emerge within invaded environments has now been realized. 
Another potentially important factor leading to the emergence of novel EuwallaceaFusarium consortia is the potential of beetle hybridization. Recent work by O’Donnell and colleagues (2015) indicates that E. validus may have hybridized with populations of Euwallacea sp. \#2 in Florida. Although further work is needed to validate these findings, if possible, such events are even more likely between E. interjectus and E. validus on account of the close genetic relationship between these beetles as well as comparably-sized male and females that would permit mating (O’Donnell et al. 2015, Cognato et al. 2015).

Unlike E. validus, fidelity between E. interjectus and their Fusarium symbionts did not hold up within the U.S. or globally. In the U.S. at least two established populations exist, each of which harbors a unique AFC member. Throughout most of the southeastern U.S., E. interjectus cultivates Fusarium sp. AF-3 (Cognato et al. 2015, Kasson et al. 2013). A second geographically disjunct population of E. interjectus exists in Eastern TX but its symbiont differs from AF-3 carrying E. interjectus that exists through most of the southeast. Results of the PCR multiplexes could not resolve the identity of the AFC symbiont of E. interjectus from TX but phylogenetic analysis of EF-1 $\alpha$ confirmed its placement within the AFC and within the clade containing known reference strains for Fusarium sp. AF-4, AF-5 and AF-12 (Fig. 2). One E. interjectus sampled from TX had a mycangial community dominated by a non-AFC FSSC member that also contained the same AFC member as found in the other sampled beetles from this same location. Previous work by Kostovcik and colleagues (2015) indicate that pre-oral mycangia are more permissive to environmental fungi, which is supported by these observations. The high incidence of non-AFC fusaria from the galleries of several Euwallacea included in this study suggest such contact with these fusaria is likely widespread.

In Asia (China and Taiwan) E. interjectus was associated with at least two different AFC members including AF-12, which was recovered from 5 of 6 E. interjectus in Taiwan (Table 2). 
Regardless, phylogenetic analysis of EF-1 $\alpha$ confirmed placement of all E. interjectus symbionts within the AFC and within the clade containing known reference strains for Fusarium sp. AF-4, AF-5 and AF-12 (Fig. 2, Table 2).

Recent phylogenetic analysis of Cytochrome Oxidase I (COI) gene of E. interjectus from Asia and the U.S. including previous specimens collected from TX and Hawaii indicate four well-supported clades including the following localities: 1) Hawaii and Thailand; 2) Vietnam, Taiwan, and Texas; 3) Okinawa (Japan); and 4) Japan and several southern U.S. states (Cognato et al. 2015). Cytochrome Oxidase I sequence data for at least one of our Taiwanese $E$. interjectus aligned with the previously defined clade 2 with other previously collected $E$. interjectus from this same location (unpublished data). Together these results, not unlike what was previously discovered in global populations of E. fornicatus (O’Donnell et al. 2015), may indicate a species complex in which closely related E. interjectus-like beetles are morphologically indistinguishable but harbor unique AFC symbionts.

E. denticulus, which was only sampled in China, harbored a phylogenetically diverse group of AFC members including 5 of which had AF-6-like symbionts based on the results of the PCR multiplexes (Fig. 2, Table 2). Interestingly these isolates did not form a monophyletic lineage with the reference Fusarium sp. AF-6 from E. sp. \#2 in FL, which may support of several possible hypotheses: 1) AF-6 is a sexually-capable AFC member as evidenced by the significant sequence diversity 2) some AF-6-like isolates are hybrid strains with AF-6 as one of the parents, 3) markers developed to discriminate AF-6 from other closely related AFC members are not specific to AF-6.

Interestingly, all but one the fusaria from E. denticulus including 9 of 10 isolates from within the AFC had fusiform conidia, which is similar to the reference strain for AF-6 but 
atypical for members of the AFC. This may offer additional support for possible hybridization with FSSC members outside the AFC.

Another interesting facet regarding E. denticulus is that this beetle species has been previously recorded from the gulf coast of U.S., although to date no live specimens from which fusaria could be recovered and characterized have been found. The range of this beetle the U.S. overlaps with that of E. sp. \#2 found in Miami-Dade Co., which cultivates two symbionts, Fusarium sp. AF-6 and AF-8, which may possibly explain the origin of one of the two known symbionts of this beetle.

E. aff. fornicatus, which currently includes at least 4 genealogically exclusive lineages (O’Donnell et al. 2015), sampled from China yielded a single AFC genotype that aligned with the clade containing known reference strains for Fusarium sp. AF-4, AF-5 and AF-12 based on EF-1 $\alpha$ sequence data (Fig. 2). A majority of the gallery-associated isolates recovered concurrently to mycangial isolates fell within the AFC. However, at least one non-AFC isolate was recovered from the galleries that aligned with other FSSC members sampled throughout this study.

In Vietnam, E. aff. anadamanensis was recovered from which AFC and non-AFC members were recovered. All AFC members the aligned with the clade containing known reference strains for Fusarium sp. AF-4, AF-5 and AF-12 based on EF-1 $\alpha$ sequence data but were genetically distinct (Fig. 2). All non-AFC FSSC members formed a single clonal lineage (Fig. 2).

\section{Conclusions}

Results from the present study show that the multiplex primer set developed by Short et al. (2017) is a useful tool in rapid identification of certain AFC members without the need for 
DNA sequencing. This molecular tool can be used when EF1- $\alpha$ sequences can't resolve AFC member IDs and is much faster and cheaper than using a multigene phylogenetic analysis. However, as additional AFC members are identified and/or introduced, primers specific to these putative species will need to be developed.

If the identity of the Euwallacea beetle is known, this multiplex tool can quickly determine if the AFC member it carries conserved based on known phylogenetically resolved symbionts. Although results of concurrent work on pathogenicity of Fusarium sp. AF-4 from E. validus and other ongoing studies by colleagues on closely related Euwallacea-fusarium consortia indicate some AFC members pose no serious threat to native species, the widespread infidelity among these beetles as well as the passive transmission of other canker-causing FSSC members pose continued and serious threats to orchard, landscape, and forest trees.

\section{References}

1. Cognato, A. I., Hoebeke, E. R., Kajimura, H., \& Smith, S. M. (2015). History of the exotic ambrosia beetles Euwallacea interjectus and Euwallacea validus (Coleoptera: Curculionidae: Xyleborini) in the United States. Journal of economic entomology, tov073.

2. O’Donnell, K., Sink, S., Libeskind-Hadas, R., Hulcr, J., Kasson, M. T., Ploetz, R. C., ... \& Duncan, R. E. (2015). Discordant phylogenies suggest repeated host shifts in the Fusarium-Euwallacea ambrosia beetle mutualism. Fungal Genetics and Biology, 82, 277290. 
3. Storer, C. G., Breinholt, J. W., \& Hulcr, J. (2015). Wallacellus is Euwallacea: molecular phylogenetics settles generic relationships (Coleoptera: Curculionidae: Scolytinae: Xyleborini). Zootaxa, 3974(3), 391.

4. Atkinson RT. 2015. Euwallacea fornicatus (Eichhoff 1868). Bark and Ambrosia Beetles of North and Central America.

5. Eskalen, A., Stouthamer, R., Lynch, S. C., Rugman-Jones, P. F., Twizeyimana, M., Gonzalez, A., and Thibault, T. (2013). Host range of Fusarium dieback and its ambrosia beetle (Coleoptera: Scolytinae) vector in southern California. Plant Disease, 97: 938-951.

6. Kasson, M. T., O’Donnell, K., Rooney, A. P., Sink, S., Ploetz, R. C., Ploetz, J. N., ... \& Smith, J. A. (2013). An inordinate fondness for Fusarium: phylogenetic diversity of fusaria cultivated by ambrosia beetles in the genus Euwallacea on avocado and other plant hosts. Fungal Genetics and Biology, 56, 147-157.

7. Mendel, Z., Protasov, A., Sharon, M., Zveibil, A., Yehuda, S. B., O’Donnell, K., ... \& Freeman, S. (2012). An Asian ambrosia beetle Euwallacea fornicatus and its novel symbiotic fungus Fusarium sp. pose a serious threat to the Israeli avocado industry. Phytoparasitica, 40(3), 235-238.

8. Mendel, Z., Protasov, A., Sharon, M., Zveibil, A., Yehuda, S. B., O’Donnell, K., ... \& Freeman, S. (2012). An Asian ambrosia beetle Euwallacea fornicatus and its novel symbiotic fungus Fusarium sp. pose a serious threat to the Israeli avocado industry. Phytoparasitica, 40(3), 235-238.

9. Short, D. P., O’Donnell, K., Stajich, J. E., Hulcr, J., Kijimoto, T., Berger, M. C., ... \& Lynch, S. C. (2017). PCR Multiplexes Discriminate Fusarium Symbionts of Invasive 
Euwallacea Ambrosia Beetles that Inflict Damage on Numerous Tree Species Throughout the United States. Plant Disease, 101(1), 233-240.

10. Short, D. P., Double, M., Nuss, D. L., Stauder, C. M., MacDonald, W., \& Kasson, M. T. (2015). Multilocus PCR assays elucidate vegetative incompatibility gene profiles of Cryphonectria parasitica in the United States. Applied and environmental microbiology, 81(17), 5736-5742.

11. Chen, Y., Dallara, P. L., Nelson, L. J., Coleman, T. W., Hishinuma, S. M., Carrillo, D., \& Seybold, S. J. (2016). Comparative morphometric and chemical analyses of phenotypes of 2 invasive ambrosia beetles (Euwallacea spp.) in the United States. Insect science.

12. Brasier, C. M. (2000). Intercontinental spread and continuing evolution of the Dutch elm disease pathogens. In The Elms (pp. 61-72). Springer US.

13. Inderbitzin, P., Davis, R. M., Bostock, R. M., \& Subbarao, K. V. (2011). The ascomycete Verticillium longisporum is a hybrid and a plant pathogen with an expanded host range. PloS one, 6(3), e18260.

14. Kostovcik, Martin, Craig C. Bateman, Miroslav Kolarik, Lukasz L. Stelinski, Bjarte H. Jordal, and Jiri Hulcr. (2015). The ambrosia symbiosis is specific in some species and promiscuous in others: evidence from community pyrosequencing. The ISME journal 9, no. 1 (2015): 126-138.

15. Kimura M. (1980). A simple method for estimating evolutionary rate of base substitutions through comparative studies of nucleotide sequences. Journal of Molecular Evolution 16:111-120.

16. Kumar S., Stecher G., and Tamura K. (2015). MEGA7: Molecular Evolutionary Genetics Analysis version 7.0 for bigger datasets. Molecular biology and evolution, msw054. 
Figures and Tables
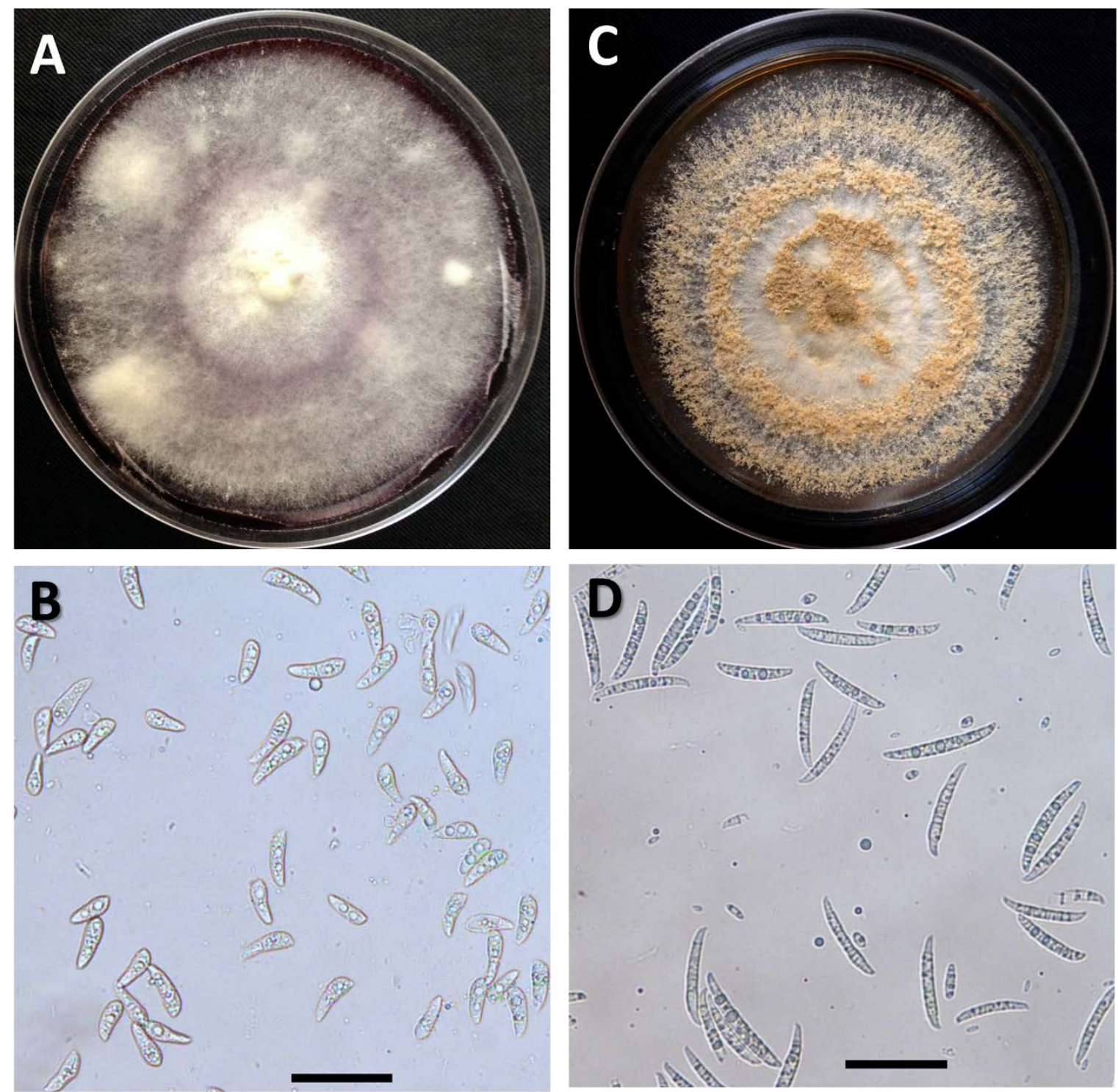

Figure 1. Comparisons of culture and macroconidial morphology for symbiotic and asymbiotic strains of members of the FSSC. A) Typical culture morphology of Fusarium sp. AF-4 (isolate Ei73) on GYE, B) clavate macroconidia of Fusarium sp. AF-4 (isolate Ei73), C) typical culture morphology of an unresolved Clade 3 FSSC member (isolate Ei66), D) typical fusiform macroconidia of an unresolved Clade 3 FSSC member (isolate Ei66). 


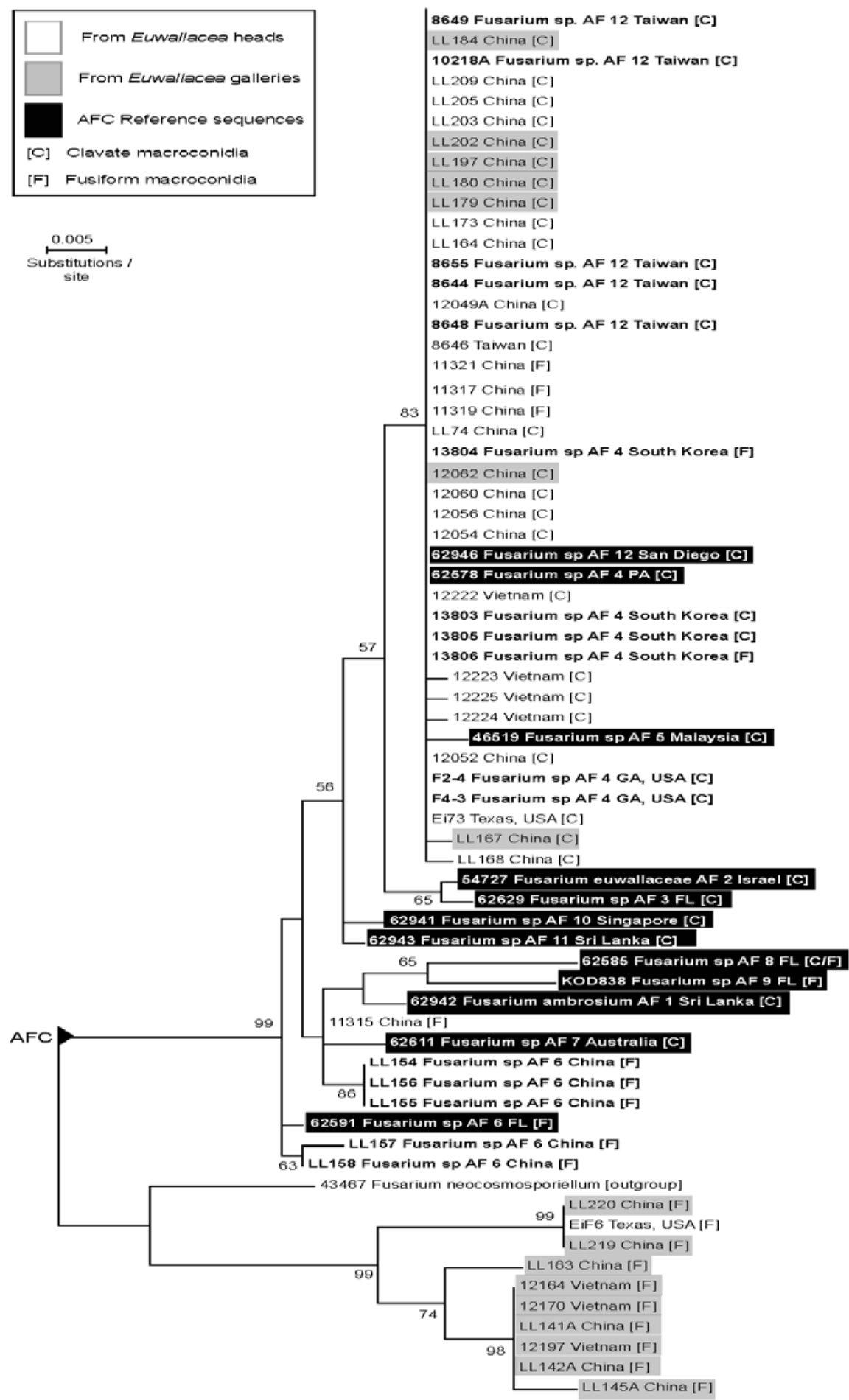


Figure 2. Molecular Phylogenetic analysis of Euwallacea-associated fusaria by Maximum Likelihood method. The evolutionary history was inferred by using the Maximum Likelihood method based on the Kimura 2-parameter model (Kimura 1980). The tree with the highest log likelihood (-1505.3653) is shown. The percentage of trees in which the associated taxa clustered together is shown next to the branches. Initial tree(s) for the heuristic search were obtained automatically by applying Neighbor-Join and BioNJ algorithms to a matrix of pairwise distances estimated using the Maximum Composite Likelihood (MCL) approach, and then selecting the topology with superior log likelihood value. A discrete Gamma distribution was used to model evolutionary rate differences among sites $(5$ categories $(+G$, parameter $=0.1774)$ ). The tree is drawn to scale, with branch lengths measured in the number of substitutions per site. The analysis involved 70 nucleotide sequences. All positions with less than $95 \%$ site coverage were eliminated. That is, fewer than 5\% alignment gaps, missing data, and ambiguous bases were allowed at any position. There were a total of 589 positions in the final dataset. Evolutionary analyses were conducted in MEGA7 (Kumar et al. 2015). 


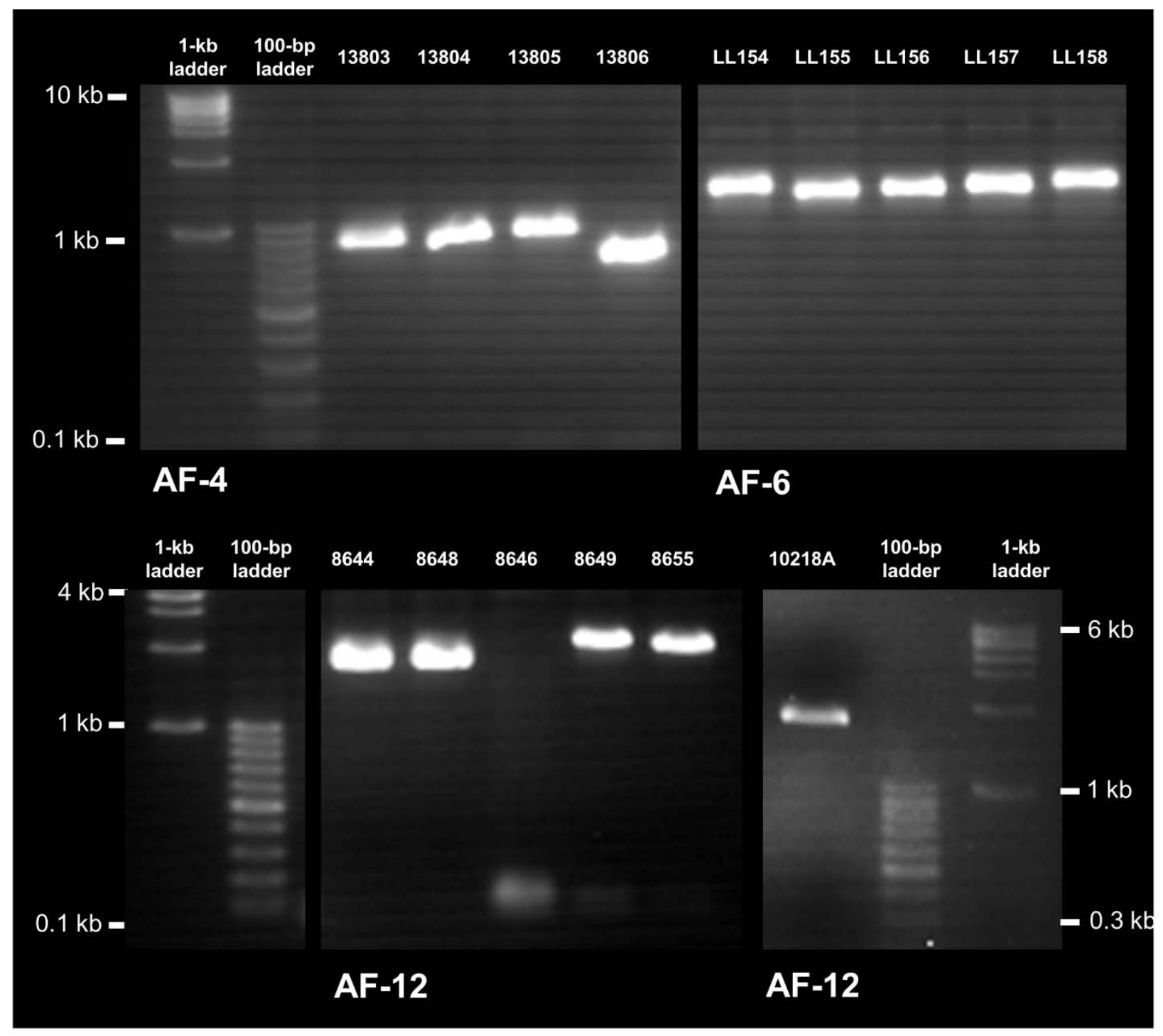

Figure 3. Gel electrophoresis of amplicons generated using three different species-specific multiplexes on AFC fusaria recovered from Euwallacea spp. in Asia. Multiplexes uncovered three previously characterized AFC members, four isolates of AF-4 from E. validus in South Korea, five isolates of AF-6 from E. denticulus in China, and five of six isolates of AF-12 from E. interjectus in Taiwan. Several gel images were cropped to include multiplex positive products and generate this composite figure but were otherwise unaltered. 
Table 1. Histories of beetles and associated fusaria included in this study

\begin{tabular}{|c|c|c|c|c|c|c|c|}
\hline $\begin{array}{l}\text { Euwallacea } \\
\text { Morphotype }\end{array}$ & Beetle ID ${ }^{\mathrm{a}}$ & $\begin{array}{l}\text { Fusarium strain } \\
\text { ID }\end{array}$ & $\begin{array}{l}\text { Country of } \\
\text { Origin }\end{array}$ & $\begin{array}{l}\text { Province/ State } \\
\text { of Origin }\end{array}$ & Specific locality & $\begin{array}{l}\text { Collection } \\
\text { details }\end{array}$ & $\begin{array}{l}\text { Fungal Colony } \\
\text { Source }\end{array}$ \\
\hline E. aff. fornicatus & & LL163 & China & Hainan & Haikou & $\begin{array}{l}\text { Infested Ficus } \\
\text { hispida }\end{array}$ & $\begin{array}{l}\text { Isolated from } \\
\text { beetle gallery }\end{array}$ \\
\hline E. aff. fornicatus & & LL202 & China & Hainan & Haikou & $\begin{array}{l}\text { Infested Ricinus } \\
\text { communis }\end{array}$ & $\begin{array}{l}\text { Isolated from } \\
\text { beetle gallery }\end{array}$ \\
\hline E. aff. fornicatus & & LL179 & China & Hainan & Haikou & $\begin{array}{l}\text { Infested } \\
\text { Mallotus apelta }\end{array}$ & $\begin{array}{l}\text { Isolated from } \\
\text { beetle gallery }\end{array}$ \\
\hline E. aff. fornicatus & & LL197 & China & Hainan & Haikou & $\begin{array}{l}\text { Infested } \\
\text { Mallotus apelta }\end{array}$ & $\begin{array}{l}\text { Isolated from } \\
\text { beetle gallery }\end{array}$ \\
\hline E. aff. fornicatus & & LL180 & China & Hainan & Danzhou & $\begin{array}{l}\text { Infested Sindora } \\
\text { glabra }\end{array}$ & $\begin{array}{l}\text { Isolated from } \\
\text { beetle gallery }\end{array}$ \\
\hline E. aff. fornicatus & 11508 (14206?) & 10249A & China & Guizhou & Guiyang & $\begin{array}{l}\text { Infested } \\
\text { Ligustrun } \\
\text { compactum }\end{array}$ & Macerated head \\
\hline E. aff. fornicatus & 11506 (14205?) & LL74 & China & Guizhou & Guiyang & $\begin{array}{l}\text { Infested Pinus } \\
\text { massoniana }\end{array}$ & Macerated head \\
\hline E. aff. fornicatus & & LL205 & China & Hainan & Haikou & $\begin{array}{l}\text { Infested Ricinus } \\
\text { communis }\end{array}$ & Macerated head \\
\hline E. aff. fornicatus & & LL203 & China & Hainan & Haikou & $\begin{array}{l}\text { Infested Ricinus } \\
\text { communis }\end{array}$ & Macerated head \\
\hline E. denticulus & & LL184 & China & Hainan & Danzhou & $\begin{array}{l}\text { Infested Sindora } \\
\text { glabra }\end{array}$ & $\begin{array}{l}\text { Isolated from } \\
\text { beetle gallery }\end{array}$ \\
\hline E. denticulus & & LL219 & China & Hainan & Sanya & $\begin{array}{l}\text { Infested } \\
\text { unknown host }\end{array}$ & $\begin{array}{l}\text { Isolated from } \\
\text { beetle gallery }\end{array}$ \\
\hline E. denticulus & & LL220 & China & Hainan & Sanya & $\begin{array}{l}\text { Infested } \\
\text { unknown host }\end{array}$ & $\begin{array}{l}\text { Isolated from } \\
\text { beetle gallery }\end{array}$ \\
\hline E. denticulus & & LL157 & China & Hainan & Danzhou & Trap-caught & Macerated head \\
\hline E. denticulus & & LL154 & China & Hainan & Danzhou & Trap-caught & Macerated head \\
\hline E. denticulus & & LL158 & China & Hainan & Danzhou & Trap-caught & Macerated head \\
\hline E. denticulus & & LL155 & China & Hainan & Danzhou & Trap-caught & Macerated head \\
\hline
\end{tabular}




\begin{tabular}{|c|c|c|c|c|c|c|c|}
\hline E. denticulus & & LL156 & China & Hainan & Danzhou & Trap-caught & Macerated head \\
\hline E. denticulus & 13726 & 11315 & China & Yunnan & Menglun & $\begin{array}{l}\text { Hand caught in- } \\
\text { flight }\end{array}$ & Macerated head \\
\hline E. denticulus & 13727 & 11317 & China & Yunnan & Menglun & $\begin{array}{l}\text { Hand caught in- } \\
\text { flight }\end{array}$ & Macerated head \\
\hline E. denticulus & 13728 & 11319 & China & Yunnan & Menglun & $\begin{array}{l}\text { Hand caught in- } \\
\text { flight }\end{array}$ & Macerated head \\
\hline E. denticulus & 13729 & 11321 & China & Yunnan & Menglun & $\begin{array}{l}\text { Hand caught in- } \\
\text { flight }\end{array}$ & Macerated head \\
\hline E. interjectus & 11503 & 12062 & China & Fujian & Fuzhou & $\begin{array}{l}\text { Infested Acacia } \\
\text { confusa }\end{array}$ & $\begin{array}{l}\text { Isolated from } \\
\text { beetle gallery }\end{array}$ \\
\hline E. interjectus & & LL167 & China & Fujian & Fuzhou & $\begin{array}{l}\text { Infested Pinus } \\
\text { massoniana }\end{array}$ & $\begin{array}{l}\text { Isolated from } \\
\text { beetle gallery }\end{array}$ \\
\hline E. interjectus & 11503 & 12054 & China & Fujian & Fuzhou & $\begin{array}{l}\text { Infested Acacia } \\
\text { confusa }\end{array}$ & Macerated head \\
\hline E. interjectus & 11503 & 12056 & China & Fujian & Fuzhou & $\begin{array}{l}\text { Infested Acacia } \\
\text { confusa }\end{array}$ & Macerated head \\
\hline E. interjectus & 11503 & 12060 & China & Fujian & Fuzhou & $\begin{array}{l}\text { Infested Acacia } \\
\text { confusa }\end{array}$ & Macerated head \\
\hline E. interjectus & & LL164 & China & Fujian & Fuzhou & $\begin{array}{l}\text { Infested Pinus } \\
\text { massoniana }\end{array}$ & Macerated head \\
\hline E. interjectus & & LL168 & China & Fujian & Fuzhou & $\begin{array}{l}\text { Infested Pinus } \\
\text { massoniana }\end{array}$ & Macerated head \\
\hline E. interjectus & & LL173 & China & Fujian & Fuzhou & $\begin{array}{l}\text { Infested Pinus } \\
\text { massoniana }\end{array}$ & Macerated head \\
\hline E. interjectus & & LL209 & China & Fujian & Fuzhou & $\begin{array}{l}\text { Infested Pinus } \\
\text { massoniana }\end{array}$ & Macerated head \\
\hline E. interjectus & 11504 & 12052 & China & Guizhou & Guiyang & $\begin{array}{l}\text { Infested } \\
\text { Ligustrum } \\
\text { compactum }\end{array}$ & Macerated head \\
\hline E. interjectus & 8389 & 7185 (8644) & Taiwan & & $\begin{array}{l}\text { Xinsheng } \\
\text { Village }\end{array}$ & Trap-caught & Macerated head \\
\hline E. interjectus & 8391 & 7189 (8646) & Taiwan & & $\begin{array}{l}\text { Xinsheng } \\
\text { Village }\end{array}$ & Trap-caught & Macerated head \\
\hline E. interjectus & 8393 & 7193 (8648) & Taiwan & & $\begin{array}{l}\text { Xinsheng } \\
\text { Village }\end{array}$ & Trap-caught & Macerated head \\
\hline E. interjectus & 8393 & 7194 (8649) & Taiwan & & $\begin{array}{l}\text { Xinsheng } \\
\text { Village }\end{array}$ & Trap-caught & Macerated head \\
\hline E. interjectus & 8397 & 7213 (8655) & Taiwan & & $\begin{array}{l}\text { Xinsheng } \\
\text { Village }\end{array}$ & Trap-caught & Macerated head \\
\hline
\end{tabular}




\begin{tabular}{|c|c|c|c|c|c|c|c|}
\hline E. interjectus & N/A & 10218A & Taiwan & & $\begin{array}{l}\text { Xinsheng } \\
\text { Village }\end{array}$ & $\begin{array}{l}\text { Infested } \\
\text { unidentified } \\
\text { Anacardiaceae } \\
\text { host }\end{array}$ & Macerated head \\
\hline E. interjectus & EiF5 & Ei73 & USA & Texas & Hempstead & $\begin{array}{l}\text { Infested } \\
\text { Magnolia } \\
\text { macrophylla }\end{array}$ & Macerated head \\
\hline E. interjectus & EiF6 & Ei66 & USA & Texas & Hempstead & $\begin{array}{l}\text { Infested } \\
\text { Magnolia } \\
\text { macrophylla }\end{array}$ & Macerated head \\
\hline $\begin{array}{l}\text { E. aff. } \\
\text { anadamanensis }\end{array}$ & 11583 & 12164 & Vietnam & Vinh Phuc & $\begin{array}{l}\text { Tam Dao } \\
\text { National Park }\end{array}$ & $\begin{array}{l}\text { Infested Pinus } \\
\text { massoniana }\end{array}$ & $\begin{array}{l}\text { Isolated from } \\
\text { beetle gallery }\end{array}$ \\
\hline $\begin{array}{l}\text { E. aff. } \\
\text { anadamanensis }\end{array}$ & 11583 & 12170 & Vietnam & Vinh Phuc & $\begin{array}{l}\text { Tam Dao } \\
\text { National Park }\end{array}$ & $\begin{array}{l}\text { Infested Pinus } \\
\text { massoniana }\end{array}$ & $\begin{array}{l}\text { Isolated from } \\
\text { beetle gallery }\end{array}$ \\
\hline $\begin{array}{l}\text { E. aff. } \\
\text { anadamanensis }\end{array}$ & 11583 & 12197 & Vietnam & Vinh Phuc & $\begin{array}{l}\text { Tam Dao } \\
\text { National Park }\end{array}$ & $\begin{array}{l}\text { Infested Pinus } \\
\text { massoniana }\end{array}$ & $\begin{array}{l}\text { Isolated from } \\
\text { beetle gallery }\end{array}$ \\
\hline $\begin{array}{l}\text { E. aff. } \\
\text { anadamanensis }\end{array}$ & 11589 & 12222 & Vietnam & Vinh Phuc & $\begin{array}{l}\text { Tam Dao } \\
\text { National Park }\end{array}$ & $\begin{array}{l}\text { Infested } \\
\text { unidentified } \\
\text { Angiosperm host }\end{array}$ & Macerated head \\
\hline $\begin{array}{l}\text { E. aff. } \\
\text { anadamanensis }\end{array}$ & 11590 & 12223 & Vietnam & Vinh Phuc & $\begin{array}{l}\text { Tam Dao } \\
\text { National Park }\end{array}$ & $\begin{array}{l}\text { Infested } \\
\text { unidentified } \\
\text { Angiosperm host }\end{array}$ & Macerated head \\
\hline $\begin{array}{l}\text { E. aff. } \\
\text { anadamanensis }\end{array}$ & 11590 & 12224 & Vietnam & Vinh Phuc & $\begin{array}{l}\text { Tam Dao } \\
\text { National Park }\end{array}$ & $\begin{array}{l}\text { Infested } \\
\text { unidentified } \\
\text { Angiosperm host }\end{array}$ & Macerated head \\
\hline $\begin{array}{l}\text { E. aff. } \\
\text { anadamanensis }\end{array}$ & 11590 & 12225 & Vietnam & Vinh Phuc & $\begin{array}{l}\text { Tam Dao } \\
\text { National Park }\end{array}$ & $\begin{array}{l}\text { Infested } \\
\text { unidentified } \\
\text { Angiosperm host }\end{array}$ & Macerated head \\
\hline E. validus & 11502 & LL141A & China & Guizhou & Guiyang & $\begin{array}{l}\text { Infested Pinus } \\
\text { massoniana }\end{array}$ & $\begin{array}{l}\text { Isolated from } \\
\text { beetle gallery }\end{array}$ \\
\hline E. validus & 11502 & LL142A & China & Guizhou & Guiyang & $\begin{array}{l}\text { Infested Pinus } \\
\text { massoniana }\end{array}$ & $\begin{array}{l}\text { Isolated from } \\
\text { beetle gallery }\end{array}$ \\
\hline E. validus & 11502 & LL145A & China & Guizhou & Guiyang & $\begin{array}{l}\text { Infested Pinus } \\
\text { massoniana }\end{array}$ & $\begin{array}{l}\text { Isolated from } \\
\text { beetle gallery }\end{array}$ \\
\hline E. validus & 12608 & 13803 & South Korea & Gyeonggi & Seoul & Trap-caught & Macerated head \\
\hline E. validus & 12609 & 13804 & South Korea & Gyeonggi & Seoul & Trap-caught & Macerated head \\
\hline E. validus & 12610 & 13805 & South Korea & Gyeonggi & Seoul & Trap-caught & Macerated head \\
\hline E. validus & 12611 & 13806 & South Korea & Gyeonggi & Seoul & Trap-caught & Macerated head \\
\hline
\end{tabular}




\begin{tabular}{|c|c|c|c|c|c|c|c|}
\hline E. validus & EvF2 & F2-4 & USA & Georgia & Rabun County & $\begin{array}{l}\text { Infested Prunus } \\
\text { serotina }\end{array}$ & Macerated head \\
\hline E. validus & EvF4 & F4-3 & USA & Georgia & Rabun County & $\begin{array}{l}\text { Infested Prunus } \\
\text { serotina }\end{array}$ & Macerated head \\
\hline
\end{tabular}

${ }^{\mathrm{a}}$ Beetle and fungus are paired with fungal isolations from macerated heads/gallery walls and beetle isolations from body region 
Table 2. Results of morphological, PCR-multiplex, and phylogenetic studies of Fusarium strains recovered from Euwallacea ambrosia beetles and their galleries from Asia and the U.S.

\begin{tabular}{|c|c|c|c|c|}
\hline $\begin{array}{l}\text { Fusarium } \\
\text { strain ID }\end{array}$ & Country of Origin & $\begin{array}{c}\text { Macrocondial } \\
\text { morphologya }\end{array}$ & AFC targets detectedb & $\begin{array}{c}\text { AFC } \\
\text { Member } \\
(\text { EF-1 } \alpha)^{d}\end{array}$ \\
\hline 8644 & Taiwan & Clavate & AF-12 & Yes \\
\hline 8648 & Taiwan & Clavate & AF-12 & Yes \\
\hline 8649 & Taiwan & Clavate & AF-12 & Yes \\
\hline 8655 & Taiwan & Clavate & $\mathrm{AF}-12$ & Yes \\
\hline 10218A & Taiwan & Clavate & AF-12 & Yes \\
\hline 13803 & South Korea & Clavate & $\mathrm{AF}-4$ & Yes \\
\hline 13805 & South Korea & Clavate & $\mathrm{AF}-4$ & Yes \\
\hline F2-4 & Georgia, USA & Clavate & $\mathrm{AF}-4$ & Yes \\
\hline F4-3 & Georgia, USA & Clavate & $\mathrm{AF}-4$ & Yes \\
\hline 13804 & South Korea & Fusiform & $\mathrm{AF}-4$ & Yes \\
\hline 13806 & South Korea & Fusiform & $\mathrm{AF}-4$ & Yes \\
\hline LL157 & China & Fusiform & AF-6 & Yes \\
\hline LL154 & China & Fusiform & AF-6 & Yes \\
\hline LL158 & China & Fusiform & AF-6 & Yes \\
\hline LL155 & China & Fusiform & AF-6 & Yes \\
\hline LL156 & China & Fusiform & AF-6 & Yes \\
\hline LL202 & China & Clavate & None detectedc & Yes \\
\hline LL179 & China & Clavate & None detected & Yes \\
\hline LL197 & China & Clavate & None detected & Yes \\
\hline LL180 & China & Clavate & None detected & Yes \\
\hline 10249A & China & Clavate & None detected & Yes \\
\hline LL74 & China & Clavate & None detected & Yes \\
\hline LL205 & China & Clavate & None detected & Yes \\
\hline LL203 & China & Clavate & None detected & Yes \\
\hline LL184 & China & Clavate & None detected & Yes \\
\hline 12062 & China & Clavate & None detected & Yes \\
\hline LL167 & China & Clavate & None detected & Yes \\
\hline 12054 & China & Clavate & None detected & Yes \\
\hline 12056 & China & Clavate & None detected & Yes \\
\hline 12060 & China & Clavate & None detected & Yes \\
\hline LL164 & China & Clavate & None detected & Yes \\
\hline LL168 & China & Clavate & None detected & Yes \\
\hline LL173 & China & Clavate & None detected & Yes \\
\hline LL209 & China & Clavate & None detected & Yes \\
\hline 12052 & China & Clavate & None detected & Yes \\
\hline 8646 & Taiwan & Clavate & None detected & Yes \\
\hline 12222 & Vietnam & Clavate & None detected & Yes \\
\hline 12223 & Vietnam & Clavate & None detected & Yes \\
\hline 12224 & Vietnam & Clavate & None detected & Yes \\
\hline 12225 & Vietnam & Clavate & None detected & Yes \\
\hline
\end{tabular}




\begin{tabular}{|c|c|c|c|c|}
\hline Ei73 & Texas, USA & Clavate & None detected & Yes \\
\hline 11315 & China & Fusiform & None detected & Yes \\
\hline 11317 & China & Fusiform & None detected & Yes \\
\hline 11319 & China & Fusiform & None detected & Yes \\
\hline 11321 & China & Fusiform & None detected & Yes \\
\hline LL163 & China & Fusiform & None detected & No \\
\hline LL219 & China & Fusiform & None detected & No \\
\hline LL220 & China & Fusiform & None detected & No \\
\hline 12164 & Vietnam & Fusiform & None detected & No \\
\hline 12170 & Vietnam & Fusiform & None detected & No \\
\hline 12197 & Vietnam & Fusiform & None detected & No \\
\hline LL141A & China & Fusiform & None detected & No \\
\hline LL142A & China & Fusiform & None detected & No \\
\hline LL145A & China & Fusiform & None detected & No \\
\hline Ei66 & Texas, USA & Fusiform & None detected & No \\
\hline
\end{tabular}

${ }^{\text {a }}$ Culture morphology was assessed 10-14 days post inoculation onto GYEA

${ }^{\mathrm{b}}$ Based on multiplex PCR developed by Short et al. 2017

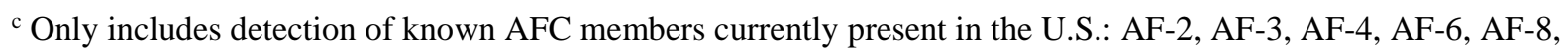
and AF-12.

${ }^{\mathrm{d}}$ Inclusion in AFC based on phylogenetic analysis of EF-1 $\alpha$ (See Fig. 2) 
Table 3. Sequence similarity between deposited U.S. strains and newly discovered targets in Asia

\begin{tabular}{|c|c|c|c|c|c|}
\hline $\begin{array}{l}\text { AFC } \\
\text { Target }\end{array}$ & Descriptiona & $\begin{array}{c}\text { Isolate } \\
\text { ID }\end{array}$ & $\begin{array}{l}\text { Size } \\
\text { (bp) }\end{array}$ & $\begin{array}{c}\% \\
\text { Sequenc } \\
\mathrm{e} \\
\text { similarit } \\
\mathrm{y}\end{array}$ & $\begin{array}{c}\text { Genbank } \\
\text { Accession } \\
\text { b }\end{array}$ \\
\hline AF-4 & $\begin{array}{l}\text { Adenylate forming domain, Class I } \\
\text { superfamily bifunctional fatty acid } \\
\text { transporter/very-long-chain acyl-CoA } \\
\text { synthetase }\end{array}$ & 13803 & 678 & 100 & KT835021 \\
\hline \multirow[t]{2}{*}{ AF-6 } & $\begin{array}{l}\text { No putative conserved domains } \\
\text { detected }\end{array}$ & LL154 & 951 & 99 & KT835022 \\
\hline & & LL155 & 951 & 99 & KT835022 \\
\hline \multirow[t]{2}{*}{ AF-12 } & $\begin{array}{l}\text { No putative conserved domains } \\
\text { detected }\end{array}$ & 8648 & 704 & 100 & KT835024 \\
\hline & & 8649 & 869 & 99 & KT835024 \\
\hline
\end{tabular}

${ }^{\text {a }}$ Based on BLASTp searches as reported in Short et al. 2017

${ }^{\mathrm{b}}$ Previously deposited by Short et al. 2017 


\section{Thesis Summary}

Ambrosia beetles will continue invading the U.S. and with them, bring exotic fungal species which may pose a threat to our native flora. Identifying the tree species which Euwallacea validus infests allows researchers to monitor what hosts may be at risk of E. validus vectored pathogens. This study suggests that none of the tree species tested were at risk of disease caused by Fusarium sp. AF-4 or Raffaelea subfusca. However as introduced Euwallacea species' ranges increase and overlap, the possibility of fungal swapping of each other's Fusarium symbionts may allow E. validus to acquire a more virulent fungal symbiont. Knowing preferred hosts of $E$. validus would then be of great importance in monitoring disease outbreaks.

The development of multiplex primer sets by Short et al. (2017) provides a tool to quickly resolve which AFC members known to occur in the U.S. a beetle is carrying without the need for time consuming and expensive multigene sequencing. With this information, fungal swapping would be easily identified. Such fungal swapping has occurred deep in the past as revealed by O’Donnell et al (2015). In a globalized world where exotic species now overlap in naïve habitats, Euwallacea and their fungal symbionts are now free to intermingle and novel disease complexes may arise as a result. 
Appendix A. Statistical Output for Comparions among Fusarium sp. AF-4 and Raffaelea subfusca mycangial symbionts across all plant hosts

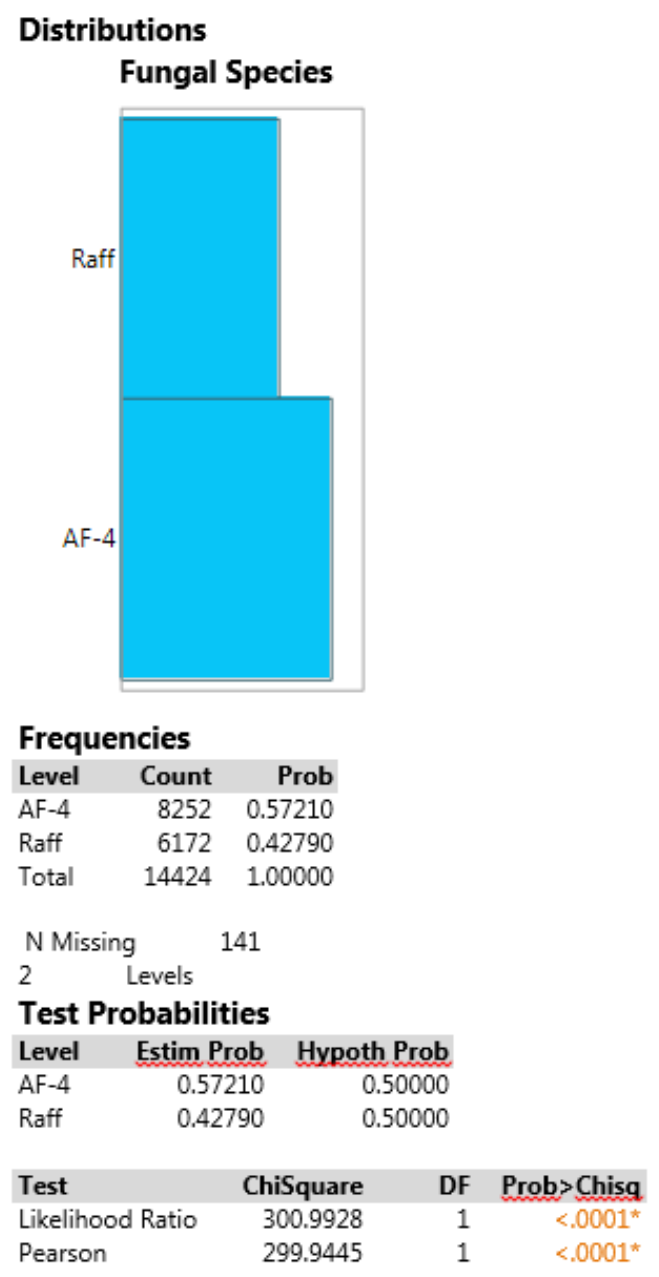

Method: Fix hypothesized values, rescale omitted 
Appendix B. Contingency Table of Comparions among Fusarium sp. AF-4 and Raffaelea subfusca Colony Forming Units (CFUs) by plant host

\begin{tabular}{|c|c|c|c|}
\hline \begin{tabular}{|l} 
Count \\
Total \% \\
Col \% \\
Row \%
\end{tabular} & AF-4 & Raff & Total \\
\hline ACPE & $\begin{array}{r}1056 \\
7.32 \\
12.80 \\
62.45\end{array}$ & $\begin{array}{r}635 \\
4.40 \\
10.29 \\
37.55 \\
\end{array}$ & $\begin{array}{r}1691 \\
11.72\end{array}$ \\
\hline ACRU & $\begin{array}{r}80 \\
0.55 \\
0.97 \\
57.55\end{array}$ & $\begin{array}{r}59 \\
0.41 \\
0.96 \\
42.45\end{array}$ & $\begin{array}{l}139 \\
0.96\end{array}$ \\
\hline AIAL & \begin{tabular}{r|}
2886 \\
20.01 \\
34.97 \\
68.75
\end{tabular} & $\begin{array}{r}1312 \\
9.10 \\
21.26 \\
31.25 \\
\end{array}$ & $\begin{array}{r}4198 \\
29.10\end{array}$ \\
\hline AMAR & $\begin{array}{r}138 \\
0.96 \\
1.67 \\
85.71\end{array}$ & $\begin{array}{r}23 \\
0.16 \\
0.37 \\
14.29\end{array}$ & $\begin{array}{r}161 \\
1.12\end{array}$ \\
\hline ARSP & \begin{tabular}{r|}
84 \\
0.58 \\
1.02 \\
45.41
\end{tabular} & $\begin{array}{r}101 \\
0.70 \\
1.64 \\
54.59\end{array}$ & $\begin{array}{r}185 \\
1.28\end{array}$ \\
\hline BELE & $\begin{array}{r}893 \\
6.19 \\
10.82 \\
73.56\end{array}$ & $\begin{array}{r}321 \\
2.23 \\
5.20 \\
26.44\end{array}$ & $\begin{array}{r}1214 \\
8.42\end{array}$ \\
\hline CEOC & \begin{tabular}{r|}
418 \\
2.90 \\
5.07 \\
63.91
\end{tabular} & $\begin{array}{r}236 \\
1.64 \\
3.82 \\
36.09\end{array}$ & $\begin{array}{r}654 \\
4.53\end{array}$ \\
\hline FRAM & \begin{tabular}{r|}
507 \\
3.51 \\
6.14 \\
39.36
\end{tabular} & \begin{tabular}{r|}
781 \\
5.41 \\
12.65 \\
60.64
\end{tabular} & $\begin{array}{r}1288 \\
8.93\end{array}$ \\
\hline PIVI & $\begin{array}{r}309 \\
2.14 \\
3.74 \\
32.39\end{array}$ & $\begin{array}{r}645 \\
4.47 \\
10.45 \\
67.61\end{array}$ & $\begin{array}{l}954 \\
6.61\end{array}$ \\
\hline
\end{tabular}

\begin{tabular}{|c|c|c|c|}
\hline POGR & $\begin{array}{r}281 \\
1.95 \\
3.41 \\
46.22 \\
\end{array}$ & $\begin{array}{r}327 \\
2.27 \\
5.30 \\
53.78 \\
\end{array}$ & $\begin{array}{r}608 \\
4.22\end{array}$ \\
\hline QUMO & $\begin{array}{r}602 \\
4.17 \\
7.30 \\
35.16 \\
\end{array}$ & $\begin{array}{r}1110 \\
7.70 \\
17.98 \\
64.84 \\
\end{array}$ & $\begin{array}{r}1712 \\
11.87\end{array}$ \\
\hline QURU & $\begin{array}{r}698 \\
4.84 \\
8.46 \\
56.02\end{array}$ & $\begin{array}{r}548 \\
3.80 \\
8.88 \\
43.98\end{array}$ & $\begin{array}{r}1246 \\
8.64\end{array}$ \\
\hline RHTY & $\begin{array}{r}67 \\
0.46 \\
0.81 \\
77.01 \\
\end{array}$ & $\begin{array}{r}20 \\
0.14 \\
0.32 \\
22.99 \\
\end{array}$ & $\begin{array}{r}87 \\
0.60\end{array}$ \\
\hline ROPS & $\begin{array}{r}233 \\
1.62 \\
2.82 \\
81.18\end{array}$ & $\begin{array}{r}54 \\
0.37 \\
0.87 \\
18.82\end{array}$ & \begin{tabular}{r|}
287 \\
1.99
\end{tabular} \\
\hline Total & $\begin{array}{r}8252 \\
57.21 \\
\end{array}$ & $\begin{array}{r}6172 \\
42.79 \\
\end{array}$ & 14424 \\
\hline
\end{tabular}

Tests

$\begin{array}{rrrr}\text { N } & \text { DF } & \text {-Loglike } & \text { RSquare (U) } \\ 14424 & 13 & 669.42035 & 0.0680\end{array}$

Test ChiSquare Prob $>$ ChiSq

Likelihood Ratio $1338.841 \quad<.0001^{*}$

Pearson $\quad 1315.350 \quad<.0001^{*}$ 
Appendix C. Mean Streaking Area ANOVA Table

\begin{tabular}{|l|r|r|r|r|r|}
\hline Analysis of Variance for Mean Streaking Area \\
\hline Effect & Num DF & Den DF & F Value & Pr> F \\
\hline Treatment & 4 & 64 & 6.25 & 0.0003 \\
\hline Tree Species & 12 & 64 & 10.97 & $<.0001$ \\
\hline Tree Species*treatment & 48 & 64 & 1.23 & 0.2169 \\
\hline
\end{tabular}


Appendix D. Contingency Table of Comparions among Canker Incidence for Fusarium

sp. AF-4 and Raffaelea subfusca Treatments across all hosts

Contingency Analysis of Cankers By Trt Species=ACPE

\begin{tabular}{|c|c|c|c|}
\hline \multicolumn{4}{|c|}{$\begin{array}{l}\text { Freg: Count } \\
\text { Contingency Table } \\
\text { Irt By Cankers }\end{array}$} \\
\hline \begin{tabular}{|l|} 
Count \\
Total $\%$ \\
Col $\%$ \\
Row $\%$ \\
\end{tabular} & \begin{tabular}{|r|} 
WithCan \\
kers \\
\end{tabular} & $\begin{array}{l}\text { Without } \\
\text { Cankers }\end{array}$ & Total \\
\hline 1 & $\begin{array}{r}13 \\
5.20 \\
27.66 \\
26.00 \\
\end{array}$ & $\begin{array}{r}37 \\
14.80 \\
18.23 \\
74.00 \\
\end{array}$ & $\begin{array}{r}50 \\
20.00\end{array}$ \\
\hline 2 & $\begin{array}{r}7 \\
2.80 \\
14.89 \\
14.00 \\
\end{array}$ & $\begin{array}{r}43 \\
17.20 \\
21.18 \\
86.00\end{array}$ & $\begin{array}{r}50 \\
20.00\end{array}$ \\
\hline 3 & \begin{tabular}{r|}
9 \\
3.60 \\
19.15 \\
18.00 \\
\end{tabular} & $\begin{array}{r}41 \\
16.40 \\
20.20 \\
82.00\end{array}$ & $\begin{array}{r}50 \\
20.00\end{array}$ \\
\hline 4 & \begin{tabular}{r|}
9 \\
3.60 \\
19.15 \\
18.00 \\
\end{tabular} & $\begin{array}{r}41 \\
16.40 \\
20.20 \\
82.00\end{array}$ & $\begin{array}{r}50 \\
20.00\end{array}$ \\
\hline 7 & \begin{tabular}{r|}
9 \\
3.60 \\
19.15 \\
18.00 \\
\end{tabular} & $\begin{array}{r}41 \\
16.40 \\
20.20 \\
82.00 \\
\end{array}$ & $\begin{array}{r}50 \\
20.00\end{array}$ \\
\hline Total & $\begin{array}{r}47 \\
18.80 \\
\end{array}$ & $\begin{array}{r}203 \\
81.20 \\
\end{array}$ & 250 \\
\hline
\end{tabular}

\section{Tests}

$\begin{array}{rrrr}\text { N } & \text { DF } & \text {-Loglike } & \text { RSquare (U) } \\ 250 & 4 & 1.2174353 & 0.0101\end{array}$

$\begin{array}{lrr}\text { Test } & \text { ChiSquare } & \text { Prob>ChiSg } \\ \text { Likelihood Ratio } & 2.435 & 0.6563 \\ \text { Pearson } & 2.515 & 0.6419\end{array}$


Contingency Analysis of Cankers By Trt Species=ACRU

Freg: Count

Contingency Table

Trt By Cankers

\begin{tabular}{|c|c|c|c|}
\hline $\begin{array}{l}\text { Count } \\
\text { Total \% } \\
\text { Col \% } \\
\text { Row \% }\end{array}$ & $\begin{array}{r}\text { WithCan } \\
\text { kers }\end{array}$ & $\begin{array}{l}\text { Without } \\
\text { Cankers }\end{array}$ & Total \\
\hline 1 & $\begin{array}{r}2 \\
0.80 \\
100.00 \\
4.00 \\
\end{array}$ & \begin{tabular}{r|}
48 \\
19.20 \\
19.35 \\
96.00 \\
\end{tabular} & $\begin{array}{r}50 \\
20.00\end{array}$ \\
\hline 2 & $\begin{array}{r}0 \\
0.00 \\
0.00 \\
0.00 \\
\end{array}$ & $\begin{array}{r}50 \\
20.00 \\
20.16 \\
100.00 \\
\end{array}$ & $\begin{array}{r}50 \\
20.00\end{array}$ \\
\hline 3 & $\begin{array}{r}0 \\
0.00 \\
0.00 \\
0.00 \\
\end{array}$ & $\begin{array}{r}50 \\
20.00 \\
20.16 \\
100.00 \\
\end{array}$ & $\begin{array}{r}50 \\
20.00\end{array}$ \\
\hline 4 & $\begin{array}{r}0 \\
0.00 \\
0.00 \\
0.00\end{array}$ & $\begin{array}{r}50 \\
20.00 \\
20.16 \\
100.00\end{array}$ & $\begin{array}{r}50 \\
20.00\end{array}$ \\
\hline 7 & $\begin{array}{r}0 \\
0.00 \\
0.00 \\
0.00 \\
\end{array}$ & $\begin{array}{r}50 \\
20.00 \\
20.16 \\
100.00\end{array}$ & $\begin{array}{r}50 \\
20.00\end{array}$ \\
\hline Total & $\begin{array}{r}2 \\
0.80 \\
\end{array}$ & $\begin{array}{r}248 \\
99.20 \\
\end{array}$ & 250 \\
\hline
\end{tabular}

Tests

\begin{tabular}{lrrr}
\multicolumn{1}{r}{$\quad$ N } & DF & -Loglike & RSquare (U) \\
\multicolumn{1}{c}{250} & 4 & 3.2513987 & 0.279 \\
& & & \\
Test & ChiSquare & Prob $>$ ChiSg \\
Likelihood Ratio & & 6.503 & 0.1646 \\
Pearson & & 8.065 & 0.0892 \\
\end{tabular}

Warning: $20 \%$ of cells have expected count less than 5 , ChiSquare suspect.

\begin{tabular}{|c|c|}
\hline Fisher's Exact & Two-sided \\
\hline Table & Prob $\leq \mathrm{P}$ \\
\hline Probability & \\
\hline 0.03 & 0.19 \\
\hline
\end{tabular}


Contingency Analysis of Cankers By Trt Species=AIAL

Freg: Count

Contingency Table

Trt By Cankers

\begin{tabular}{|c|c|c|c|}
\hline $\begin{array}{l}\text { Count } \\
\text { Total \% } \\
\text { Col \% } \\
\text { Row \% }\end{array}$ & $\begin{array}{r}\text { WithCan } \\
\text { kers }\end{array}$ & $\begin{array}{l}\text { Without } \\
\text { Cankers }\end{array}$ & Total \\
\hline 1 & $\begin{array}{r}0 \\
0.00 \\
0.00 \\
0.00\end{array}$ & $\begin{array}{r}50 \\
14.29 \\
14.41 \\
100.00\end{array}$ & $\begin{array}{r}50 \\
14.29\end{array}$ \\
\hline 2 & $\begin{array}{r}1 \\
0.29 \\
33.33 \\
2.00\end{array}$ & $\begin{array}{r}49 \\
14.00 \\
14.12 \\
98.00\end{array}$ & $\begin{array}{r}50 \\
14.29\end{array}$ \\
\hline 3 & $\begin{array}{r}0 \\
0.00 \\
0.00 \\
0.00 \\
\end{array}$ & $\begin{array}{r}50 \\
14.29 \\
14.41 \\
100.00 \\
\end{array}$ & $\begin{array}{r}50 \\
14.29\end{array}$ \\
\hline 4 & $\begin{array}{r}0 \\
0.00 \\
0.00 \\
0.00 \\
\end{array}$ & $\begin{array}{r}50 \\
14.29 \\
14.41 \\
100.00\end{array}$ & $\begin{array}{r}50 \\
14.29\end{array}$ \\
\hline 5 & $\begin{array}{r}0 \\
0.00 \\
0.00 \\
0.00 \\
\end{array}$ & $\begin{array}{r}100 \\
28.57 \\
28.82 \\
100.00 \\
\end{array}$ & $\begin{array}{r}100 \\
28.57\end{array}$ \\
\hline 7 & $\begin{array}{r}2 \\
0.57 \\
66.67 \\
4.00\end{array}$ & $\begin{array}{r}48 \\
13.71 \\
13.83 \\
96.00\end{array}$ & $\begin{array}{r}50 \\
14.29\end{array}$ \\
\hline Total & $\begin{array}{r}3 \\
0.86 \\
\end{array}$ & $\begin{array}{r}347 \\
99.14\end{array}$ & 350 \\
\hline
\end{tabular}

Tests

$\begin{array}{rrrr}\mathbf{N} & \text { DF } & \text {-LogLike } & \text { RSquare (U) } \\ 350 & 5 & 3.9659055 & 0.2297\end{array}$

Test ChiSquare Prob $>$ ChiSg

Likelihood Ratio $\quad 7.932 \quad 0.1600$

$\begin{array}{lll}\text { Pearson } & 8.742 & 0.1198\end{array}$

Warning: $20 \%$ of cells have expected count less than 5, ChiSquare suspect. 
Contingency Analysis of Cankers By Trt Species=ARSP

Freq: Count

\section{Contingency Table}

Irt By Cankers

\begin{tabular}{|l|r|r|r|}
\hline Count & WithCan & Without & Total \\
Total \% & kers & Cankers & \\
Col \% & & & \\
Row \% & & & \\
\hline 1 & 3 & 47 & 50 \\
& 1.20 & 18.80 & 20.00 \\
& 11.54 & 20.98 & \\
& 6.00 & 94.00 & \\
\hline 2 & 2 & 48 & 50 \\
& 0.80 & 19.20 & 20.00 \\
& 7.69 & 21.43 & \\
& 4.00 & 96.00 & \\
\hline 3 & 3 & 47 & 50 \\
& 1.20 & 18.80 & 20.00 \\
& 11.54 & 20.98 & \\
& 6.00 & 94.00 & \\
\hline 4 & 3 & 47 & 50 \\
& 1.20 & 18.80 & 20.00 \\
& 11.54 & 20.98 & \\
& 6.00 & 94.00 & \\
\hline 7 & 15 & 35 & 50 \\
& 6.00 & 14.00 & 20.00 \\
& 57.69 & 15.63 & \\
\hline Total & 30.00 & 70.00 & \\
\hline & 26 & 224 & 250 \\
\hline
\end{tabular}

Tests

$\begin{array}{rrrr}\text { N } & \text { DF } & \text {-Loglike } & \text { RSquare (U) } \\ 250 & 4 & 10.460453 & 0.1254\end{array}$

$\begin{array}{lrr}\text { Test } & \text { ChiSquare } & \text { Prob }>\text { ChiSq } \\ \text { Likelihood Ratio } & 20.921 & 0.0003^{*} \\ \text { Pearson } & 25.927 & <.0001^{*}\end{array}$

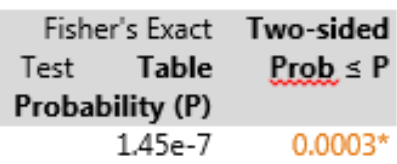


Contingency Analysis of Cankers By Trt Species=BELE

Freq: Count

\section{Contingency Table}

Trt By Cankers

\begin{tabular}{|c|c|c|c|}
\hline $\begin{array}{l}\text { Count } \\
\text { Total \% } \\
\text { Col \% } \\
\text { Row \% }\end{array}$ & $\begin{array}{r}\text { WithCan } \\
\text { kers }\end{array}$ & $\begin{array}{l}\text { Without } \\
\text { Cankers }\end{array}$ & Total \\
\hline 1 & $\begin{array}{r}4 \\
1.14 \\
17.39 \\
8.00\end{array}$ & $\begin{array}{r}46 \\
13.14 \\
14.07 \\
92.00\end{array}$ & $\begin{array}{r}50 \\
14.29\end{array}$ \\
\hline 2 & $\begin{array}{r}11 \\
3.14 \\
47.83 \\
22.00 \\
\end{array}$ & $\begin{array}{r}39 \\
11.14 \\
11.93 \\
78.00 \\
\end{array}$ & $\begin{array}{r}50 \\
14.29\end{array}$ \\
\hline 3 & $\begin{array}{r}1 \\
0.29 \\
4.35 \\
2.00\end{array}$ & $\begin{array}{r}49 \\
14.00 \\
14.98 \\
98.00\end{array}$ & $\begin{array}{r}50 \\
14.29\end{array}$ \\
\hline 4 & $\begin{array}{r}5 \\
1.43 \\
21.74 \\
10.00\end{array}$ & $\begin{array}{r}45 \\
12.86 \\
13.76 \\
90.00\end{array}$ & $\begin{array}{r}50 \\
14.29\end{array}$ \\
\hline 5 & $\begin{array}{r}0 \\
0.00 \\
0.00 \\
0.00\end{array}$ & $\begin{array}{r}100 \\
28.57 \\
30.58 \\
100.00\end{array}$ & $\begin{array}{r}100 \\
28.57\end{array}$ \\
\hline 7 & $\begin{array}{r}2 \\
0.57 \\
8.70 \\
4.00\end{array}$ & $\begin{array}{r}48 \\
13.71 \\
14.68 \\
96.00\end{array}$ & $\begin{array}{r}50 \\
14.29\end{array}$ \\
\hline Total & $\begin{array}{r}23 \\
6.57\end{array}$ & $\begin{array}{r}327 \\
93.43\end{array}$ & 350 \\
\hline
\end{tabular}

\section{Tests}

$\begin{array}{rrrr}\text { N } & \text { DF } & \text {-LogLike } & \text { RSquare (U) } \\ 350 & 5 & 15.006083 & 0.1769\end{array}$

$\begin{array}{lrr}\text { Test } & \text { ChiSquare } & \text { Prob }>\text { ChiSq } \\ \text { Likelihood Ratio } & 30.012 & <.0001^{*} \\ \text { Pearson } & 29.783 & <.0001^{*}\end{array}$

Warning: $20 \%$ of cells have expected count less than 5 , ChiSquare suspect.

\begin{tabular}{rrr}
\multicolumn{2}{c}{ Fisher's Exact } & Two-sided \\
Test Table & Prob $\leq \mathbf{P}$ \\
Probability (P) & \\
$1.852 \mathrm{e}-9$ & $<.0001^{*}$
\end{tabular}


Contingency Analysis of Cankers By Trt Species $=$ CEOC

\section{Contingency Table}

Trt By Cankers

\begin{tabular}{|l|r|r|r|}
\hline Count & WithCan & Without & Total \\
Total \% & kers & Cankers & \\
Col \% & & & \\
Row \% & & & \\
\hline 1 & 1 & 49 & 50 \\
& 0.40 & 19.60 & 20.00 \\
& 100.00 & 19.68 & \\
& 2.00 & 98.00 & \\
\hline 2 & 0 & 50 & 50 \\
& 0.00 & 20.00 & 20.00 \\
& 0.00 & 20.08 & \\
& 0.00 & 100.00 & \\
\hline 3 & 0 & 50 & 50 \\
& 0.00 & 20.00 & 20.00 \\
& 0.00 & 20.08 & \\
& 0.00 & 100.00 & \\
\hline 4 & 0 & 50 & 50 \\
& 0.00 & 20.00 & 20.00 \\
& 0.00 & 20.08 & \\
& 0.00 & 100.00 & \\
\hline 7 & 0 & 50 & 50 \\
& 0.00 & 20.00 & 20.00 \\
& 0.00 & 20.08 & \\
\hline Total & 0.00 & 100.00 & \\
\hline & 1 & 249 & 250 \\
\hline & 0.40 & 99.60 & \\
\hline
\end{tabular}

Tests

$\begin{array}{rrrr}\text { N } & \text { DF } & \text {-LogLike } & \text { RSquare (U) } \\ 250 & 4 & 1.6175026 & 0.2481\end{array}$

$\begin{array}{lrr}\text { Test } & \text { ChiSquare } & \text { Prob }>\text { ChiSg } \\ \text { Likelihood Ratio } & 3.235 & 0.5193 \\ \text { Pearson } & 4.016 & 0.4038\end{array}$

Warning: $20 \%$ of cells have expected count less than 5, ChiSquare suspect.

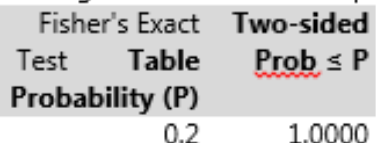




\begin{tabular}{|c|c|c|c|}
\hline \multicolumn{4}{|c|}{$\begin{array}{l}\text { Freg: Count } \\
\text { Contingency Table } \\
\text { Irt By Cankers }\end{array}$} \\
\hline $\begin{array}{l}\text { Count } \\
\text { Total } \% \\
\text { Col } \% \\
\text { Row } \%\end{array}$ & $\begin{array}{r}\text { WithCan } \\
\text { kers } \\
\end{array}$ & $\begin{array}{l}\text { Without } \\
\text { Cankers }\end{array}$ & Total \\
\hline 1 & $\begin{array}{r}49 \\
19.60 \\
20.59 \\
98.00\end{array}$ & \begin{tabular}{r|}
1 \\
0.40 \\
8.33 \\
2.00
\end{tabular} & $\begin{array}{r}50 \\
20.00\end{array}$ \\
\hline 2 & $\begin{array}{r}60 \\
24.00 \\
25.21 \\
100.00\end{array}$ & $\begin{array}{r}0 \\
0.00 \\
0.00 \\
0.00\end{array}$ & $\begin{array}{r}60 \\
24.00\end{array}$ \\
\hline 3 & \begin{tabular}{r|}
47 \\
18.80 \\
19.75 \\
94.00 \\
\end{tabular} & $\begin{array}{r}3 \\
1.20 \\
25.00 \\
6.00\end{array}$ & $\begin{array}{r}50 \\
20.00\end{array}$ \\
\hline 4 & $\begin{array}{r}39 \\
15.60 \\
16.39 \\
97.50 \\
\end{array}$ & \begin{tabular}{r|}
1 \\
0.40 \\
8.33 \\
2.50 \\
\end{tabular} & $\begin{array}{r}40 \\
16.00\end{array}$ \\
\hline 7 & $\begin{array}{r}43 \\
17.20 \\
18.07 \\
86.00\end{array}$ & $\begin{array}{r}7 \\
2.80 \\
58.33 \\
14.00\end{array}$ & $\begin{array}{r}50 \\
20.00\end{array}$ \\
\hline Total & $\begin{array}{r}238 \\
95.20 \\
\end{array}$ & $\begin{array}{r}12 \\
4.80 \\
\end{array}$ & 250 \\
\hline
\end{tabular}

\section{Tests}

\begin{tabular}{|c|c|c|c|}
\hline $\mathbf{N}$ & DF & -LogLike & RSquare (U) \\
\hline 250 & 4 & 6.9711493 & 0.1448 \\
\hline Test & & iSquare & rob $>$ ChiSg \\
\hline Likelihood Ratio & & 13.942 & $0.0075^{*}$ \\
\hline Pearson & & 13.765 & $0.0081^{*}$ \\
\hline
\end{tabular}

Warning: $20 \%$ of cells have expected count less than 5, ChiSquare suspect.

\begin{tabular}{|c|c|}
\hline Fisher's Exact & Two-sided \\
\hline Table & Prob $\leq \mathrm{P}$ \\
\hline Probabilit & \\
\hline $4.114 \mathrm{e}$ & $0.0071^{*}$ \\
\hline
\end{tabular}


Contingency Analysis of Cankers By Trt Species=PIVI

Freg: Count

Contingency Table

Trt By Cankers

\begin{tabular}{|c|c|c|c|}
\hline $\begin{array}{l}\text { Count } \\
\text { Total \% } \\
\text { Col \% } \\
\text { Row \% }\end{array}$ & \begin{tabular}{|r|} 
WithCan \\
kers
\end{tabular} & $\begin{array}{l}\text { Without } \\
\text { Cankers }\end{array}$ & Total \\
\hline 1 & $\begin{array}{r}0 \\
0.00 \\
0.00 \\
0.00\end{array}$ & $\begin{array}{r}50 \\
20.00 \\
20.00 \\
100.00\end{array}$ & $\begin{array}{r}50 \\
20.00\end{array}$ \\
\hline 2 & $\begin{array}{r}0 \\
0.00 \\
0.00 \\
\end{array}$ & $\begin{array}{r}50 \\
20.00 \\
20.00 \\
100.00 \\
\end{array}$ & $\begin{array}{r}50 \\
20.00\end{array}$ \\
\hline 3 & $\begin{array}{r}0 \\
0.00 \\
0.00 \\
\end{array}$ & $\begin{array}{r}50 \\
20.00 \\
20.00 \\
100.00 \\
\end{array}$ & $\begin{array}{r}50 \\
20.00\end{array}$ \\
\hline 4 & $\begin{array}{r}0 \\
0.00 \\
0.00 \\
\end{array}$ & $\begin{array}{r}50 \\
20.00 \\
20.00 \\
100.00 \\
\end{array}$ & $\begin{array}{r}50 \\
20.00\end{array}$ \\
\hline 7 & \begin{tabular}{r|}
0 \\
0.00 \\
0.00
\end{tabular} & $\begin{array}{r}50 \\
20.00 \\
20.00 \\
100.00\end{array}$ & $\begin{array}{r}50 \\
20.00\end{array}$ \\
\hline Total & $\begin{array}{r}0 \\
0.00\end{array}$ & $\begin{array}{r}250 \\
100.00\end{array}$ & 250 \\
\hline
\end{tabular}

Tests

$\begin{array}{rrrr}\text { N } & \text { DF } & \text {-Loglike } & \text { RSquare (U) } \\ 250 & 0 & 0 & \end{array}$

Test ChiSquare Prob $>$ ChiSg

Likelihood Ratio $\quad 0.000$

Pearson $\quad 0.000$ 


\section{Contingency Analysis of Cankers By Trt Species=POGR}

Ereg: Count

Contingency Table

Trt By Cankers

\begin{tabular}{|l|r|r|r|}
\hline Count & WithCan & Without & Total \\
Total \% & kers & Cankers & \\
Col \% & & & \\
Row \% & & & \\
\hline 1 & 38 & 12 & 50 \\
& 15.20 & 4.80 & 20.00 \\
& 22.22 & 15.19 & \\
& 76.00 & 24.00 & \\
\hline 2 & 42 & 8 & 50 \\
& 16.80 & 3.20 & 20.00 \\
& 24.56 & 10.13 & \\
& 84.00 & 16.00 & \\
\hline 3 & 29 & 21 & 50 \\
& 11.60 & 8.40 & 20.00 \\
& 16.96 & 26.58 & \\
& 58.00 & 42.00 & \\
\hline 4 & 33 & 17 & 50 \\
& 13.20 & 6.80 & 20.00 \\
& 19.30 & 21.52 & \\
& 66.00 & 34.00 & \\
\hline 7 & 29 & 21 & 50 \\
& 11.60 & 8.40 & 20.00 \\
& 16.96 & 26.58 & \\
\hline Total & 58.00 & 42.00 & \\
\hline & 171 & 79 & 250 \\
\hline & 68.40 & 31.60 & \\
\hline
\end{tabular}

Tests

\begin{tabular}{|c|c|c|c|}
\hline $\mathbf{N}$ & DF & -LogLike & RSquare (U) \\
\hline 250 & 4 & 6.3359167 & 0.0406 \\
\hline Test & & hiSquare & Prob $>$ ChiSg \\
\hline Likelihood Ratio & & 12.672 & $0.0130^{*}$ \\
\hline Pearson & & 12.103 & $0.0166^{*}$ \\
\hline
\end{tabular}


Contingency Analysis of Cankers By Trt Species=QUMO

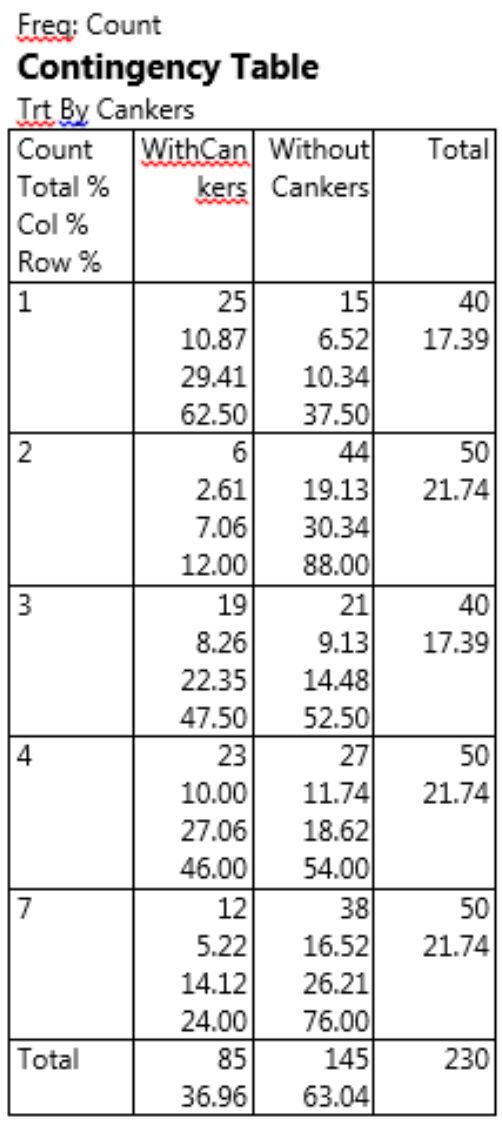

\section{Tests}

$\begin{array}{rrrr}\text { N } & \text { DF } & \text {-Loglike } & \text { RSquare (U) } \\ 230 & 4 & 16.970662 & 0.1120\end{array}$

Test ChiSquare Prob>ChiSg

Likelihood Ratio $\quad 33.941 \quad<.0001^{*}$

Pearson $\quad 31.834<<0001^{*}$ 


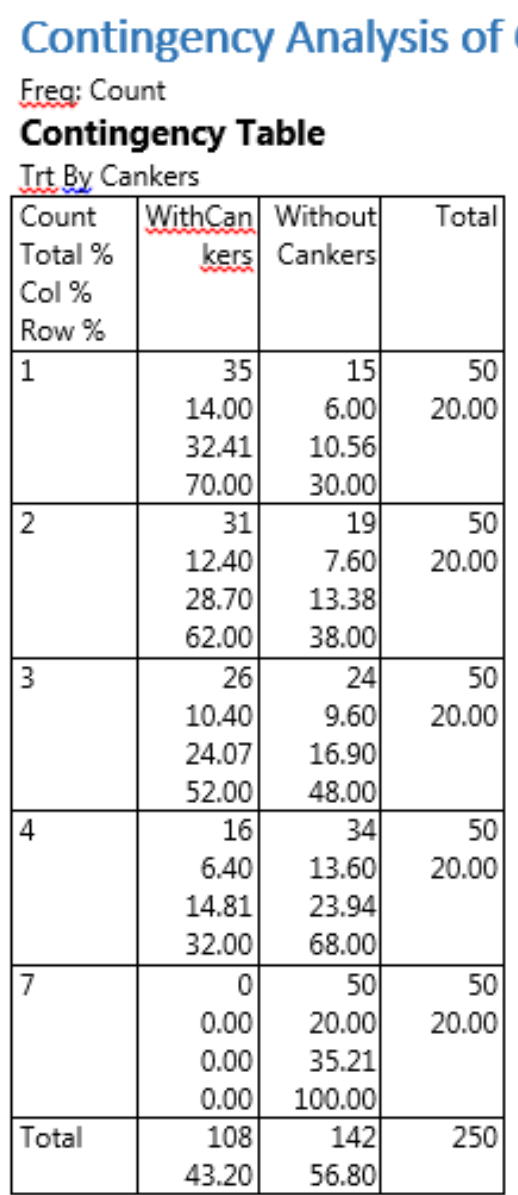

Tests

\begin{tabular}{rrrr} 
N & DF & -LogLike & RSguare (U) \\
\hline 250 & 4 & 41.260372 & 0.2413
\end{tabular}

\begin{tabular}{lrr} 
Test & ChiSquare & Prob $>$ ChiSg \\
\hline Likelihood Ratio & 82.521 & $<.0001^{*}$ \\
Pearson & 64.000 & $<.0001^{*}$
\end{tabular}




\begin{tabular}{|c|c|c|c|}
\hline \multicolumn{4}{|c|}{$\begin{array}{l}\text { Freg: Count } \\
\text { Contingency Table } \\
\text { Trt By Cankers }\end{array}$} \\
\hline \begin{tabular}{|l|} 
Count \\
Total $\%$ \\
Col \% \\
Row $\%$ \\
\end{tabular} & \begin{tabular}{r|} 
WithCan \\
kers
\end{tabular} & $\begin{array}{l}\text { Without } \\
\text { Cankers }\end{array}$ & Total \\
\hline 1 & \begin{tabular}{r|}
20 \\
10.00 \\
25.32 \\
50.00
\end{tabular} & $\begin{array}{r}20 \\
10.00 \\
16.53 \\
50.00\end{array}$ & $\begin{array}{r}40 \\
20.00\end{array}$ \\
\hline 2 & \begin{tabular}{r|}
14 \\
7.00 \\
17.72 \\
35.00
\end{tabular} & \begin{tabular}{r|}
26 \\
13.00 \\
21.49 \\
65.00
\end{tabular} & $\begin{array}{r}40 \\
20.00\end{array}$ \\
\hline 3 & $\begin{array}{r}13 \\
6.50 \\
16.46 \\
32.50 \\
\end{array}$ & $\begin{array}{r}27 \\
13.50 \\
22.31 \\
67.50\end{array}$ & $\begin{array}{r}40 \\
20.00\end{array}$ \\
\hline 4 & \begin{tabular}{r|}
14 \\
7.00 \\
17.72 \\
46.67
\end{tabular} & \begin{tabular}{r|}
16 \\
8.00 \\
13.22 \\
53.33
\end{tabular} & $\begin{array}{r}30 \\
15.00\end{array}$ \\
\hline 7 & $\begin{array}{r}18 \\
9.00 \\
22.78 \\
36.00\end{array}$ & \begin{tabular}{r|}
32 \\
16.00 \\
26.45 \\
64.00 \\
\end{tabular} & $\begin{array}{r}50 \\
25.00\end{array}$ \\
\hline Total & $\begin{array}{r}79 \\
39.50\end{array}$ & $\begin{array}{r}121 \\
60.50\end{array}$ & 200 \\
\hline
\end{tabular}

\section{Tests}

$\begin{array}{rrrr}\text { N } & \text { DF } & \text {-LogLike } & \text { RSquare (U) } \\ 200 & 4 & 1.9408340 & 0.0145\end{array}$

\begin{tabular}{lrr} 
Test & ChiSquare & Prob>ChiSg \\
\hline Likelihood Ratio & 3.882 & 0.4223 \\
Pearson & 3.906 & 0.4189
\end{tabular}


Contingency Analysis of Cankers By Trt Species=ROPS

Freg: Count

\section{Contingency Table}

Irt By Cankers

\begin{tabular}{|l|r|r|r|}
\hline Count & WithCan & Without & Total \\
Total \% & kers & Cankers & \\
Col \% & & & \\
Row \% & & & \\
\hline 1 & 40 & 10 & 50 \\
& 16.00 & 4.00 & 20.00 \\
& 19.70 & 21.28 & \\
& 80.00 & 20.00 & \\
\hline 2 & 43 & 7 & 50 \\
& 17.20 & 2.80 & 20.00 \\
& 21.18 & 14.89 & \\
& 86.00 & 14.00 & \\
\hline 3 & 34 & 16 & 50 \\
& 13.60 & 6.40 & 20.00 \\
& 16.75 & 34.04 & \\
& 68.00 & 32.00 & \\
\hline 4 & 48 & 2 & 50 \\
& 19.20 & 0.80 & 20.00 \\
& 23.65 & 4.26 & \\
& 96.00 & 4.00 & \\
\hline 7 & 38 & 12 & 50 \\
& 15.20 & 4.80 & 20.00 \\
& 18.72 & 25.53 & \\
\hline Total & 76.00 & 24.00 & \\
\hline & 203 & 47 & 250 \\
\hline & 81.20 & 18.80 & \\
\hline
\end{tabular}

\section{Tests}

$$
\begin{array}{rrrr}
\text { N } & \text { DF } & \text {-LogLike } & \text { RSquare (U) } \\
250 & 4 & 8.2645063 & 0.0684
\end{array}
$$

\begin{tabular}{lrr} 
Test & ChiSquare & Prob>ChiSg \\
\hline Likelihood Ratio & 16.529 & $0.0024^{*}$ \\
Pearson & 14.569 & $0.0057^{*}$
\end{tabular}

\begin{tabular}{|l|l|l|}
\hline Trt & Species & Isolate \\
\hline 1 & Fusarium sp. AF-4 & WV 8 \\
\hline 2 & Fusarium sp. AF-4 & WV 10 \\
\hline 3 & Raffaelea subfusca & WV 3 \\
\hline 4 & Raffaelea subfusca & WV 110 \\
\hline 7 & Negative Control & N/A \\
\hline
\end{tabular}

